\title{
VARIABILIDADE PATOGÊNICA DE ISOLADOS DE Mycosphaerella musicola E RESISTÊNCIA INDUZIDA E GENÉTICA EM GENÓTIPOS DE BANANEIRA
}

\section{ZILTON JOSÉ MACIEL CORDEIRO}

Engenheiro Agrônomo

Orientador: Prof. Dr. HIROSHI KIMATI

Tese apresentada à Escola Superior de Agricultura "Luiz de Queiroz". Universidade de São Paulo, para obtenção do título de Doutor em Agronomia. Área de Concentração: Fitopatologia.

PIRACICABA

Estado de São Paulo-Brasil

Novembro-1997 
Dados Internacionais de Catalogação na Publicação (CIP) DIVISÃo DE BIBLIOTECA E DOCUMENTAÇÃO - Campus "Luiz de Queiroz"/USP

Cordeiro, Zilton José Maciel

Variabilidade Patogênica de isolados de Mycosphaerella musicola e resistência induzida e genética em genótipos de bananeira / Zilton José Maciel Cordeiro. - Piracicaba, 1997.

$118 \mathrm{p}$.

Tese (doutorado) - Escola Superior de Agricultura Luiz de Queiroz, 1997.

Bibliografia.

1. Cercosporiose-da-bananeira 2. Doença de planta 3. Fungo fitopatogênico 4. Genética vegetal 5 . Resistência à doença 6 . Variabilidade patogênica I. Titulo 


\section{VARIABILIDADE PATOGÊNICA DE ISOLADOS DE Mycosphaerella musicola E RESISTÊNCIA INDUZIDA E GENÉTICA EM GENÓTIPOS DE BANANEIRA}

\section{ZILTON JOSÉ MACIEL CORDEIRO \\ Engenheiro Agrônomo}

Aprovada em: 17/12/1997

Comissão julgadora:

Prof. Dr. Hiroshi Kimati

ESALQ/USP

Prof. Dr.Tasso Leo Krugner

ESALQ/USP

Prof. Dr.Sérgio Florentino Pascholati

ESALQ/USP

Pesq.Dr. Aristóteles Pires de Matos

EMBRAPA/CNPMF

Prof. Dr. Chukichi Kurozawa

UNESP/Botucatu

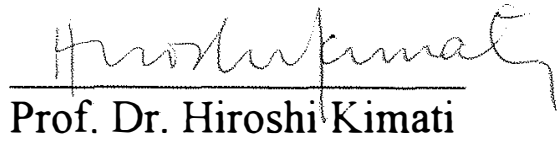

Orientador 
A memória dos meus pais

Zuza e Zeca e do meu

irmào Zilmar, dedico.

A minha esposa Ruthe meus filhos Zilton Junior, Paulo, Cássia e Joice, ofereço. 


\section{AGRADECIMENTOS}

Gostaria de deixar registrados aqui meus sinceros agradecimentos:

- Ao Centro Nacional de Pesquisa de Mandioca e Fruticultura Tropical (CNPMF) da Empresa Brasileira de Pesquisa Agropecuária (Embrapa), pela oportunidade de realizar este curso;

- Ao meu colega Aristóteles Pires de Matos que, com muito esforço e espírito profissional, assumiu as minhas funções no programa de pesquisa com banana no CNPMF, durante o meu afastamento;

- Ao colega Jorge Loyola, que durante o meu afastamento, representou-me legalmente junto ao CNPMF/Embrapa, prestando enorme colaboração em assuntos diversos;

- Aos colegas: Lair Victor da Epamig-Lavras-MG; Luíz Alberto Saes do IACRegistro-SP; Roberto Moura, Augusto Tibúrcio e João Emanuel do IPARecife-PE; Álvaro Figueiredo, Luadir Gasparoto e José Clério do CPAA/Embrapa-Manaus-AM; Jorge Loyola e Domingos Ramos do CNPMF/Embrapa-Cruz das Almas-BA; Jailton Cordeiro da Fazenda Campo Alegre-Turmalina-MG e Amauri Siviero do CPAA/Embrapa-Rio Branco- 
AC, que gentilmente enviaram folhas doentes de bananeira, para obtenção dos isolados de Pseudocercospora musae;

- À minha esposa Ruth Eugenia, pelo apoio e auxílios prestados durante a realização do curso;

- Aos meus filhos Zilton Junior e Paulo Eugenio, pelo imenso auxílio prestado na montagem dos experimentos, coleta de dados e digitação;

- À CAPES (Coordenadoria de Aperfeiçoamento de Pessoal de Nível Superior), pelo apoio financeiro, através da bolsa de doutorado;

- Ao Departamento de Fitopatologia, pela oportunidade de realizar o curso;

- Aos professores do Departamento de Fitopatologia, pelo tratamento cortês e pelos ensinamentos aqui recebidos;

- Ao professor Hiroshi Kimati pela orientação, apoio. confiança e amizade, manifestados durante o curso;

- Aos funcionários do Departamento de Fitopatologia, pela amizade;

- A todos os colegas de curso, pela amizade e apoio recebidos durante o mesmo;

- Aos colegas Pimentel e Silvânia, pelo apoio e troca de experiências durante a realização do exame de qualificação; 
- Aos colegas Fernando Cintra, Carlos Estevão, Pimentel e Goes, pela amizade e convívio familiar extra ESALQ;

- Aos colegas Leonardo e Ângela, pelas sugestões e amizade;

- Ao professor Carlos Tadeu Dias, do Departamento de Matemática e Estatística, pelo valioso auxílio nas análises estatísticas;

- Aos meus irmãos e irmãs, sobrinhos e cunhados, pelo pensamento positivo nos momentos mais dificeis, pelo apoio, pela amizade, pela união, pelo amor;

- Ao professor Tasso Leo Krugner, pela presteza na elaboração dos abstracts;

- Aos membros da banca examinadora: Prof. Sérgio Florentino Pascholati, Prof. Tasso Leo Krugner, Prof. Hiroshi Kimati, Prof. Chukichi Kurozawa e Dr. Aristóteles Pires de Matos, pelas correções e sugestões apresentadas;

- À coordenação do curso de pós graduação em Fitopatologia, pela atenção e apoio prestados durante a realização do curso;

- Aos bananicultores e irmãos João, Paulo e Moacir, por ter cedido o bananal para instalação do experimento de campo e pelo enorme apoio prestado durante a realização do mesmo;

- A todos que direta ou indiretamente contribuiram para a realização deste trabalho. 


\section{SUMÁRIO}

Página

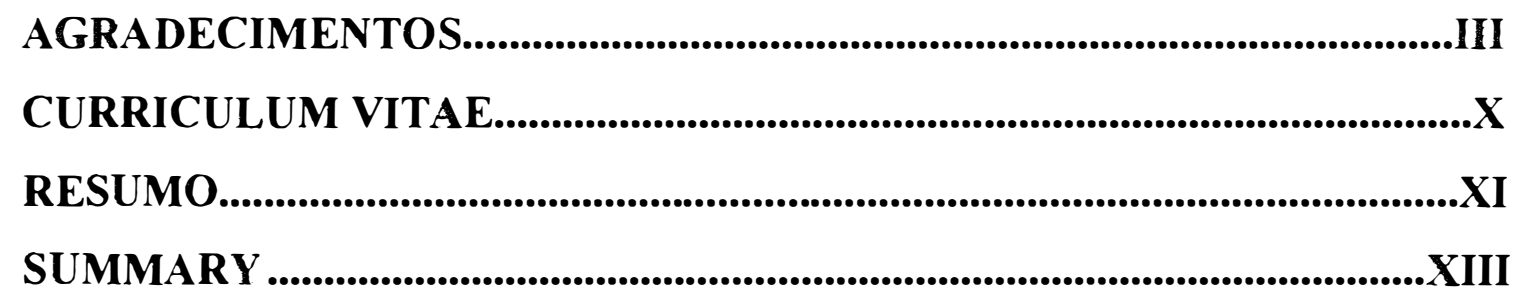

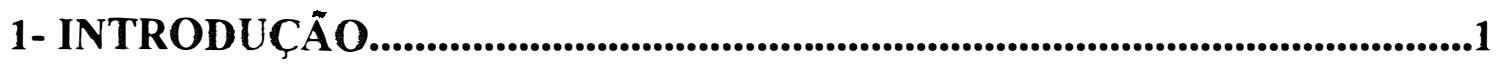

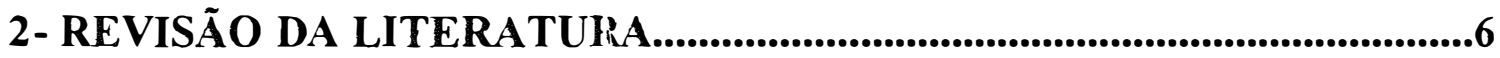

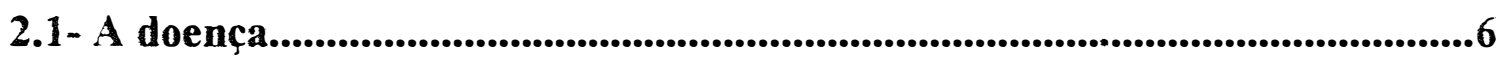

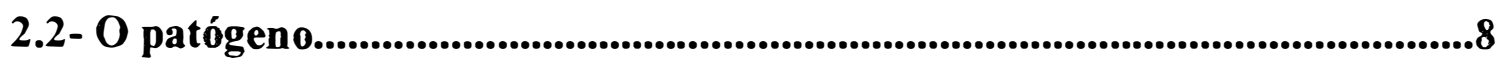

2.3- Variabilidade em Mycosphaerella musicola........................................................10

2.4- Resistência do gênero Musa à Mycosphaerella.................................................14

2.4.1- Aspectos gerais da resistência......................................................................14

2.4.2- Aspectos específicos da resistência........................................................................16

2.4.2.1 - Avaliações a nível de campo..........................................................................16

2.4.2.2- Avaliações a nível de casa de vegetação......................................................18

2.4.2.3- Características da resistência........................................................................20

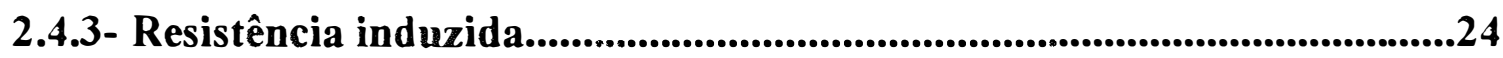


CAPÍTULO I .29

3- VARIABILIDADE PATOGÊNICA EM Mycosphaerella musicola ............29

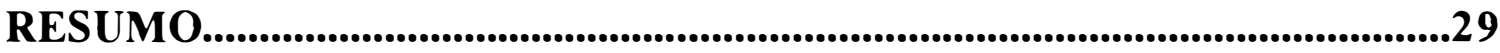

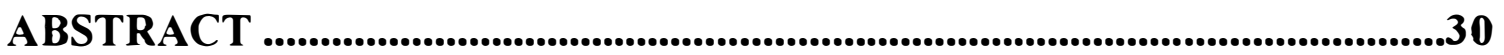

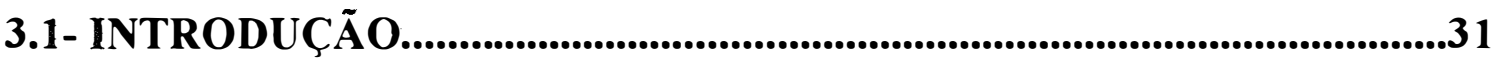

3.2- MATERIAL E MÉTODOS.......................................................................32

3.2.1- Obtenção dos isolados...........................................................................................33

3.2.2- Testes de Patogenicidade.......................................................................................34

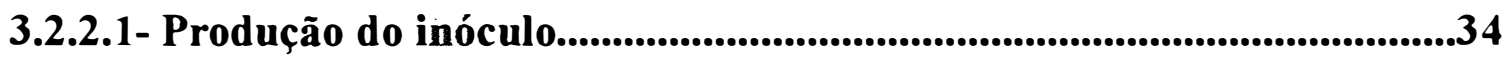

3.2.2.2- Avaliação da patogenicidade........................................................................34

3.2.3- Estudos de variabilidade.................................................................................35

3.2.3.1- Produção do inóculo..........................................................................................35

3.2.3.2- Inoculação...........................................................................................................36

3.2.3.3- Parâmetros avaliados..............................................................................................36

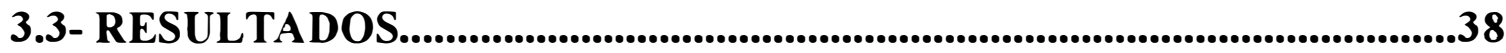

3.3.1- Testes de patogenicidade........................................................................................ 38

3.3.2- Testes de variabilidade...............................................................................................38

3.4- DISCUSSÃO...................................................................................................4

3.5- REFERÊNCIAS BIBLIOGRÁFICAS.............................................................46

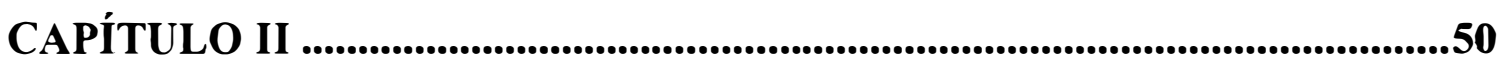

4- INDUÇÃO DE RESISTÊNCIA À Mycosphaerella musicola EM BANANEIRA (Musa spp) ................................................................50

RESUMO...........................................................................................................................................50

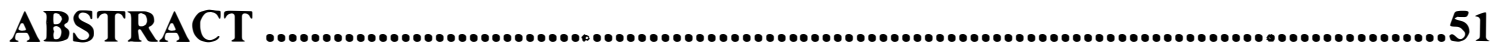

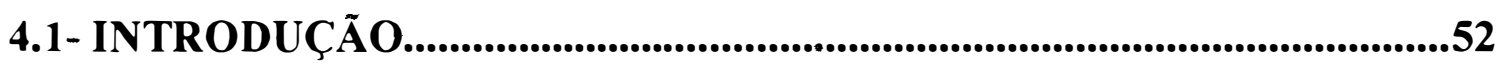

4.2- MATERIAL DE MÉTODOS..................................................................54 


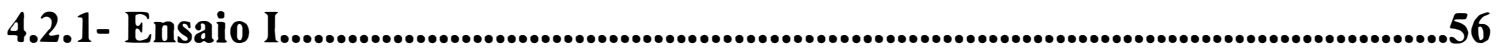

4.2.1.1- Parâmetros avaliados....................................................................................55

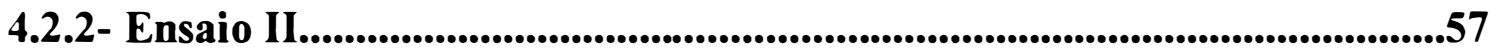

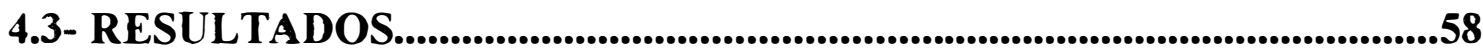

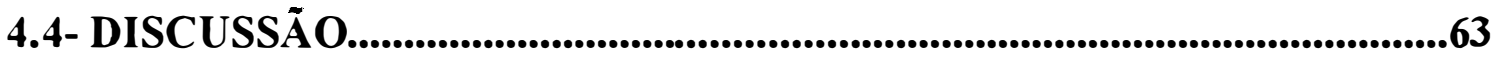

4.5- REFERÊNCIAS BIBLIOGRÁFICAS..............................................................66

CAPÍTULO III.............................................................................................................69

5- RESISTÊNCIA DE GENÓTIPOS DE BANANEIRA

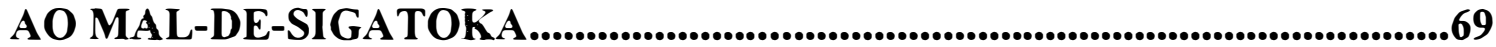

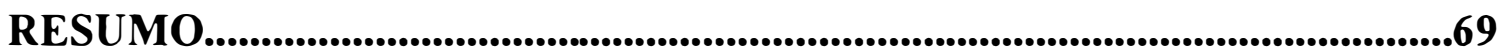

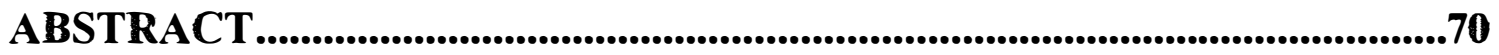

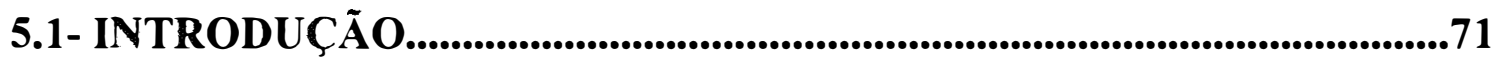

5.2- MATERIAL E MÉTODOS...........................................................................74

5.2.1- Avaliação da resistência de genótipos de bananeira

sob condições de telado...................................................................................................74

5.2.1.1- Dados coletados...................................................................................................75

5.2.2- Avaliação da resistência de genótipos de bananeira

sob condições naturais de infecção..................................................................................76

5.2.2.1- Dados coletados.......................................................................................................77

5.3- RESULTADOS............................................................................................

5.3.1- Dados obtidos em condições de telado...........................................................79

5.3.2- Dados obtidos em condições de campo............................................................79

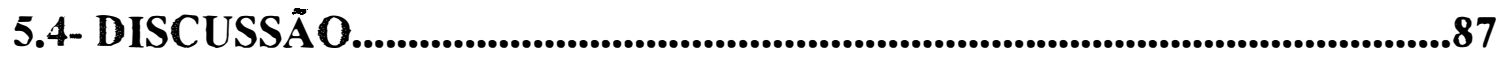

5.4.1- Experimento em telado........................................................................................................87

5.4.2- Experimento de campo...................................................................................95

5.5- REFERÊNCIAS BIBLIOGRÁFICAS................................................................100 
6- CONCLUSÕES GERAIS.......................................................................107

7- REFERÊNCIAS BIBLIOGRÁFICAS GERAIS.......................................109 


\section{CURRICULUM VITAE}

Zilton José Maciel Cordeiro, filho de José Cordeiro de Oliveira e Maria José Cordeiro Maciel. Nascido em 22/04/1954, é natural de Turmalina-MG, onde concluiu o primeiro grau.

Formou-se Técnico Agrícola, em 1974, no Colégio Agrícola Antônio Versiani Athayde, da Universidade Federal de Minas Gerais (UFMG), em Montes Claros-MG.

Engenheiro Agrônomo, pela Universidade Federal de Viçosa (UFV), em 1978 e Mestre em Fitopatologia, pela mesma Universidade em 1981.

Contratado pelo Centro Nacional de Pesquisa de Mandioca e Fruticultura Tropical (CNPMF) da Empresc $\varkappa_{\star}$ Brasileira de Pesquisa Agropecuária (Embrapa), em 19/01/1982, passou a exercer a função de pesquisador na área de Fitopatologia, junto à Equipe de Banana do CNPMF, permanecendo até 1993.

Em março de 1994, iniciou o curso de Doutorado em Fitopatologia, na Escola Superior de Agricultura "Luiz de Queiroz" (ESALQ) da Universidade de São Paulo (USP), em Piracicaba-SP. 


\section{VARIABILIDADE PATOGÊNICA DE ISOLADOS DE Mycosphaerella musicola E RESISTÊNCIA INDUZIDA E GENÉTICA EM GENÓTIPOS DE BANANEIRA}

Autor: Zilton José Maciel Cordeiro Orientador: Prof. Dr. Hiroshi Kimati

\section{RESUMO}

A espécie Mycosphaerella musicola Leach (forma anamórfica Pseudocercospora musae (Zimm) Deighton) é o mais importante patógeno da bananeira no Brasil, causador da doença mal-de-Sigatoka, Sigatoka amarela ou cercosporiose. Apesar da importância do patógeno em estudo, nada se conhece sobre a sua variabilidade patogênica e pouco se conhece sobre a interação patógeno-hospedeiro no que diz respeito à resistência. Com base nestas observações, elaborou-se o presente trabalho com objetivos de avaliar a presença de variabilidade patogênica entre isolados de $M$. musicola, avaliar e caracterizar a resistência induzida em variedades de banana, suscetíveis ao malde-Sigatoka, quando inoculadas com raças incompatíveis de M. musicola e/ou quando inoculadas com raças compatíveis, mas mantidas em ambiente impróprio ao desenvolvimento da doença; avaliar a resistência genética à Sigatoka amarela 
apresentada por diferentes genótipos de bananeira e chegar a uma metodologia de avaliação da resistência, capaz de substituir a tradicional avaliação de campo.

Os ensaios foram conduzidos nos laboratórios e telados do Departamento de Fitopatologia da ESALQ/USP, em Piracicaba-SP e em área de produtor, no município de Tietê-SP. A obtenção dos isolados foi feita a partir de folhas com manchas nos estádios IV e V, coletadas diretamente no campo ou recebidas via correio totalizando 34 isolados de diferentes cultivares e regiões. A multiplicação dos mesmos foi feita em meio V8 (100 $\mathrm{ml}$ de suco V8, $2 \mathrm{~g}$ de $\mathrm{CaCO}_{3}, 15 \mathrm{~g}$ de ágar e $900 \mathrm{ml}$ de água), mediante repicagem multiponto, seguida de incubação em câmara biotronnette mark III, sob luz constante e temperatura de $25^{\circ} \mathrm{C} \pm 2^{\circ} \mathrm{C}$ por cerca de dez dias. Seguiram-se os testes de patogenicidade, realizados sobre as variedades Prata Anã, Pacovan e Nanicão. Os isolados patogênicos foram mantidos em meio BDA (Batata, Dextrose e Ágar) cobertos com óleo mineral. Posteriormente, os mesmos foram recuperados e multiplicados conforme já definido. A inoculação, para os testes de variabilidade e resistência foi feita com suspensão contendo $4.10^{4}$ conídios $/ \mathrm{ml}$, atomizada na face inferior das folhas 1 e 2 . Seguiu-se à incubação em telado com flutuação da umidade, mediante irrigação por aspersão sobre copa. Dezoito isolados passaram pelos testes de variabilidade, mediante inoculação sobre as diferencidoras 'Prata Anã', 'Pacovan', 'Nanicão', 'Mysore', 'Terra', 'Yangambi' e 'Pioneira', sobre as quais, coletaram-se os dados de frequência de lesões e severidade. A partir desses dados foram selecionados os seis isolados de maior agressividade e com variação em virulência, realizando-se os testes de resistência sobre os genótipos Prata Anã, Pacovan, Nanicão, Mysore, Terra, Yangambi, Pioneira, JV03-15, PV03-44, FHIA-01 e FHIA-18. Foram tomados os dados de período de incubação (P.I.), periodo de latência (P.L.), período de desenvolvimento da doença (P.D.D.), freqüência de lesões por $50 \mathrm{~cm}^{2}$ de folha e severidade da doença. No campo apenas a variedade Terra não foi avaliada. Tomaram-se os dados de P.I., P.L., P.D.D., folha mais jovem infectada 
(F.M.J.I.), folha mais jovem manchada (F.M.J.M.) e severidade da doença (S.D.), transformada posteriormente em índice de doença (I. D.).

Os resultsdos mostraram uma alta variabilidade patogênica dentro de $P$. musae, confirmando a presença de raças dentro da espécie. Quanto à resistência induzida, apresentada pelas variedades Nanicão e Prata Anã, ela se caracterizou pelo caráter sistêmico, alta magnitude e persistência, mostrando-se ativa por cerca de quatro meses após a indução, entrando, posteriormente em declínio. A resistência genética dos onze genótipos em relação aos seis isolados mostrou uma interação genótipo-isolado altamente significativa para os parâmetros freqüência de lesão e severidade, caracterizando uma resistência predominantemente vertical. As interações resultaram em fenótipos característicos de hipersensibilidade como em 'Yangambi' e 'Terra', reações classificadas como alta resistência, fenotipicamente caracterizadas pela paralisação do desenvolvimento das lesões até o estádio III (estrias); genótipos resistentes, mas que permitiram ao patógeno completar o seu ciclo com drástica redução no número de lesões adultas e os genótipos suscetíveis, atingindo alta severidade. As avaliações de campo também apresentaram resultados semelhantes, porém, em função da variabilidade já demonstrada, não têm a mesma importância dos dados obtidos em telado. Isto sugere que, a partir destas informações, as avaliações de resistência à Sigatoka amarela devem considerar a variação em virulência do patógeno e, para tanto, necessita que as avaliações em condições controladas estejam aliadas às avaliações de campo. 


\title{
PATHOGENIC VARIABILITY OF Mycosphaerella musicola ISOLATES AND INDUCED AND GENETIC RESISTANCE OF BANANA GENOTYPES
}

\author{
Author: Zilton José Maciel Cordeiro \\ Adviser: Prof. Dr. Hiroshi kimati
}

\section{SUMMARY}

Mycosphaerella musicola (=Pseudocercospora musae) is the most important banana pathogen in Brazil, causing the Sigatoka disease (yellow Sigatoka or cercosporiose). Regardless the importance of the disease, nothing is known about the pathogenic variability of the pathogen and little is known about the host-pathogen interaction in relation to resistance. The present study had, thus, the following objectives: to evaluate the pathogenic variability among isolates of M. musicola ; to evaluate the occurrence of induced resistance of susceptible banana varieties after inoculation with incompatible races of the pathogen or after inoculation with the compatible races, but kept in unappropriate environment for disease development; and to evaluate the resistance of different 
banana genotypes against the disease and to develop a methodology for resistance evaluation to replace the traditional field evaluation.

Trials were carried out under laboratory and screen shading conditions in Piracicaba -SP and field conditions, in Tietê-SP. Thirty four isolates were obtained from leaf spots in stages IV and V, directly in the field or through the mail, envolving different cultivars and regions. Inoculum was obtained on V8 medium ( $100 \mathrm{ml}$ of $\mathrm{V} 8$ juice, $2 \mathrm{~g}$ of $\mathrm{CaCO}_{3}, 15 \mathrm{~g}$ of agar and $900 \mathrm{ml}$ of water), after incubation under continuous light, at $25 \pm 2{ }^{\circ} \mathrm{C}$, for about 10 days. Pathogenicity tests were performed on the varieties Prata Anã, Pacovan and Nanicão. Pathogenic isolates were then maintained on potato-dextrose-agar under mineral oil and recovered whenever necessary. Inoculation for variability and resistance study was performed by the atomization of the abaxial surface the leaves 1 and 2 with a conidial suspension $\left(4.10^{4} \mathrm{conidia} / \mathrm{ml}\right)$. Inoculated plants were kept under a shading screen and irrigated daily by sprinkling water. Eighteen isolates were tested for variability by their inoculation on the differential varieties Prata Anã, Pacovan, Nanicão, Mysore, Terra, Yangambi and Pioneira. Data of lesion frequency and disease severity were obtained and 6 isolates isolates selected for aggressiveness and virulence. These isolates were subsequently inoculated on different genotypes (Prata Anã, Pacovan, Nanicão, Mysore, Terra, Yangambi,Pioneira, JV03-15, PV03-44, FHIA-01 and FHIA-18) for resistance evaluation. Data of incubation period (I.P.), latency period (L.P.), disease development period (D.D.P.), lesion frequency in $50 \mathrm{~cm}^{2}$ of leaf and disease severity were obtained. In the field, 'Terra' was the only variety not tested. Besides the data on I.P., L.P., D.D.P. and disease severity (transformed in disease index), data on the youngest leaf infected and youngest leaf with spotting were taken in the field.

The results showed a high pathogenic variability among isolates of $M$. musicola, confirming the existence of races within the species. Induced 
resistance, shown by varieties Nanicão and Prata Anã, was shown to be systemic, of high magnitude and persistente, being active up to 4 months after induction, declining afterwards. There was a highly significant banana genotype-pathogen isolate interaction in the resistance test which employed 11 genotypes and 6 isolates, indicating a resistance predominantly vertical. Hipersensibility, was found typicaly in Yangambi and Terra, indicating high resistance, phenotypicaly characterized by the paralization of lesion development up to the stage III (leaf streaking). Resistant genotypes were also detected showing drastic reduction in the number of adult lesions, but permited the pathogen to complete its cycle. Susceptible genotypes showed high disease severity. Field evaluations gave similar results, but as a consequence of the variability observed, do not have the same importance of those obtained under controlled conditions, taking into account the variation in the pathogen virulence. 


\section{1- INTRODUÇÃO}

A bananicultura está entre as atividades agrícolas de maior expressão econômica e social no Brasil. As estatísticas apontam para uma produção anual em torno de seis milhões de toneladas e uma área plantada ao redor de quinhentos mil hectares, os quais estão distribuidos por todo o território nacional. A importância desta cultura, para o país, pode ser medida pela quantidade produzida, pelo crescimento da área plantada, que passou de 277.744 ha em 1970, para 514.367 ha em 1995, mas principalmente, pela quantidade da fruta que é consumida. Das seis milhões de toneladas produzidas anualmente, apenas 12.492 toneladas foram exportadas em 1995 (Centro Nacional de Pesquisa de Mandioca e Fruticultura Tropical-CNPMF, 1997), colocando os brasileiros entre os maiores consumidores mundiais desta fruta. Se descontarmos a exportação mais as perdas (cerca de $30 \%$ ) chega-se à cifra de aproximadamente quatro milhões de toneladas efetivamente consumidas anualmente. A grande maioria desta produção está a cargo de pequenos produtores que têm na banana sua entrada semanal de recursos, justificando assim o fato desses produtores em perímetros irrigados sempre destinarem parte de sua área disponivel, para o plantio de banana.

No cenário mundial, $85 \%$ da produção de banana está concentrada nos continentes Asiático e Americano. Entre os países maiores produtores, a Índia ocupa a primeira posição, o Brasil a segunda e muito próximo, no terceiro lugar, está o Equador, seguido por China, Filipinas e Idonésia. A produção mundial de banana vem crescendo enormemente, atingindo a média de $49,34 \%$ no período 
compreendido entre 1979 e 1996. A nível interno, a produção está assim distribuida: Região Nordeste 37,38\%; Região Sudeste 26,39\%; Região Norte 18,84\%; Região Sul 11,50\% e Centro-Oeste 5,89\%. Entre os estados maiores produtores destacam-se a Bahia, Pará, São Paulo, Pernambuco, Santa Catarina e Minas Gerais (CNPMF, 1997).

No âmbito do seu cultivo, a bananeira é afetada por diversos problemas fitossanitários causados por fungos, bactérias, vírus e insetos. Dentre estes, os fungos são os agentes infecciosos mais importantes, causando doenças como Mal-do-Panamá, manchas foliares como Sigatoka amarela, Sigatoka negra e diversas outras de menor importância, além das manchas e podridões causadas em frutos. As Sigatokas destacam-se como os principais problemas da cultura, exigindo constantemente a intervenção do homem com práticas de controle químico, para garantir alta produtividade e qualidade de fruto. A nível internacional, a Sigatoka negra (Mycosphaerella fijiensis) é o problema mais sério da cultura, destacando-se pela sua maior agressividade o que consequentemente dificulta as ações de controle (Stover \& Simmonds, 1987 ; Marim Vargas \& Romero Calderón, /1989?/).

Para o Brasil, no entanto, a Sigatoka amarela, causada por Mycosphaerella musicola Leach (= Pseudocercospora musae (Zimm.) Deighton), continua sendo a doença mais importante, até porque a Sigatoka negra ainda não foi constatada no país. As perdas provocadas pela mesma são da ordem de $50 \%$ da produção, segundo avaliações realizadas no Vale do Ribeira em São Paulo (Martinez, 1970). Os prejuízos são advindos da morte precoce das folhas com consequente enfraquecimento da planta, refletindo na produção na forma de redução do número de pencas e tamanho de frutos, maturação precoce dos mesmos no campo e perfilhamento lento. A doença é de ocorrência endêmica com picos epidêmicos durante o período chuvoso, ou seja, em geral a umidade é o fator limitante para o crescimento da mesma a níveis economicamente importantes. Somente em 
períodos muito curtos, temperaturas baixas ocorrendo no Sul e Sudeste do país limitariam o seu desenvolvimento (Cordeiro \& Kimati, 1997). A obtenção de altas produções e com frutos de boa qualidade requer que medidas de controle sejam adotadas. Neste caso. o controle químico pode ser uma alternativa, mas o alto custo do mesmo e o baixo nível técnico da maioria dos cultivos, torna a sua adoção limitada a um pequeno grupo de produtores. $\mathrm{O}$ uso da resistência genética é a alternativa priorizada no país pelas seguintes razões : é facilmente encontrada em genótipos de Musa acuminata e Musa balbisiana, é facilmente transferida à descendência em programas de hibridação (Dantas et al., 1993 ; Dantas et al. 1993a), o que propicia o estabelecimento de programas de melhoramento genético para obtenção de variedades resistentes, gerando assim uma tecnologia acessível a todos os estratos de produtores e, além de tudo, preservadora do ambiente. Fry (1982) enfatiza que o uso de variedades resistentes é um dos mais atrativos caminhos, para suprimir doença de plantas. Seu uso não depende da ação do produtor durante a fase de crescimento das plantas, não é destrutiva ao ambiente, é geralmente compatível com outras técnicas de manejo de doença e, muitas vezes é suficiente para manter a doença em níveis toleráveis. A resistência induzida, definida como a ativação de mecanismos de defesa que estão latentes em plantas suscetíveis (Pascholate \& Leite, 1995), embora não atenda todas as características destacadas por Fry (1982), pode tornar-se uma importante arma no controle do mal-de-Sigatoka.

Para o bom andamento de um programa de melhoramento, visando a obtenção de variedades resistentes, um passo importante é o conhecimento do patógeno no que diz respeito à sua variabilidade patogênica, bem como o conhecimento de metodologias capazes de discriminar, entre um grupo de genótipos, aqueles que apresentam resistência ou suscetibilidade. Com base nestas considerações, foram traçados os seguintes objetivos para este trabalho: 
1- Avaliar e caracterizar a resistência à Sigatoka amarela apresentada por diferentes genótipos de bananeira;

2- Estabelecer uma metodologia de avaliação da resistência à Sigatoka amarela, sob condições controladas, capaz de substituir a tradicional avaliação de campo;

3- Identificar alguma variabilidade patogênica em isolados de $M$. musicola, de origem geográfica e cultivar diferentes;

4- Avaliar e caracterizar a resistência induzida em variedades de banana, suscetíveis ao mal-de-Sigatoka, quando inoculadas com raças incompatíveis de M. musicola e/ou quando inoculadas com raças compatíveis, sendo porém, mantidas em ambiente impróprio ao desenvolvimento da doença.

Os objetivos acima traçados suscitaram a formulação das seguintes hipóteses científicas:

1- Se existe variabilidade entre os genótipos de bananeira em avaliação e se as condições ambientais e de inóculo são adequadas para o estabelecimento da interação patógeno-hospedeiro, então será possível, mediante a avaliação de parâmetros monocíclicos e policíclicos a discriminação entre os níveis de resistência dos diversos genótipos, bem como, discutir algumas características da resistência observada.

2- Se M. musicola está sujeita à mutação, um dos principais mecanismos de criação de variabilidade em fungos, à variação genética criada pelas vias da heterocariose e anastomose de hifas entre isolados e espécies diferentes, à ocorrência da variabilidade gerada pela reprodução sexual e, considerando a 
diversidade de ambientes e a variabilidade do hospedeiro, nos quais a doença tem ocorrido, o que poderia forçar mudanças adaptativas na espécie pelas vias da coevolução, então espera-se encontrar, entre isolados de regiões e cultivares diferentes, variações patogênicas entre os mesmos.

3- Se a bananeira é capaz de responder à inoculação com raças incompatíveis de M. musicola, exibindo resistência induzida contra isolados compatíveis, então espera-se comprovar e caracterizar tal fenômeno, mediante uma inoculação com raça incompativel seguida por inoculação desafiadora com isolado de comprovada virulência sobre a variedade em estudo. 


\section{2- REVISÃO DA LITERATURA}

\section{1- A doença}

O mal-de-Sigatoka é também conhecido como Sigatoka amarela ou Cercosporiose da bananeira. Foi constatado pela primeira vez, em Java, em 1902, e os primeiros prejuizos de importância ocorreram, em 1913, nas Ilhas Fiji, distrito de Sigatoka, de onde lhe veio o nome mal-de-Sigatoka. Em 1923, foi constatada em Queensland, Austrália e, em 1934, apareceu no Suriname e Trinidade (Simmonds, 1933 ; Stael, 1937). Nos anos seguintes a doença apareceu na Guatemala, México, Cuba, Haiti, Jamaica, Costa Rica, Panamá, Colômbia, Martinica, Guadalupe, Peru, Equador, etc. Apesar de algumas controvérsias, a doença teria sido registrada no Brasil, no estado do Amazonas, em 1944, espalhando-se posteriormente por todo o território nacional (Issa, 1953; Kimati \& Galli,1980 ; Martinez, 1984). Onde a Sigatoka negra ainda não se faz presente, como é o caso do Brasil, a Sigatoka amarela é a doença mais importante da cultura. $\mathrm{O}$ ataque às folhas da planta leva à necrose, ao decréscimo de tecido fotossintético e, consequente perda na produção, refletindo em menor número de pencas por cacho, menor tamanho de fruto e menor número de frutos por cacho. Além disto, a doença acelera a taxa de maturação de frutos, levando à maturação precoce dos mesmos no campo. A severidade da doença depende das condições climáticas determinadas pela umidade e temperatura, podendo levar, em alguns 
microclimas, à destruição total da àrea fotossintetizante da planta com perda total da produção (Cordeiro \& Kimati, 1997 ; Fouré, 1994).

A infeç̧ão ocorre através dos estômatos localizados na face inferior das folhas mais jovens da planta, atingindo a folha vela ou zero, um, dois e três. O controle químico, ainda a principal arma dos produtores contra a doença, deve preocupar-se em proteger estas folhas. Os primeiros sintomas, quando as condições são favoráveis ao desenvolvimento da doença, aparecem entre as nervuras secundárias da segunda até a quarta folhas como uma leve descoloração em forma de ponto, progredindo-se para estrias amarelas, estrias marrons, manchas necróticas e, por fim, lesões necróticas com centro deprimido, de coloração cinza, circundada por um halo amarelo (Stover,1972 ; Stover \& Simmonds, 1987). São descritos por Brun (1963), citado por Stover (1972), cinco estádios de desenvolvimento da doença, cada um com características próprias:

Estádio I- Fase de ponto ou estria de no máximo $1 \mathrm{~mm}$ de comprimento com leve descoloração.

Estádio II- Corresponde a uma estria já apresentando vários milímetros de comprimento com um processo de descoloração mais intenso.

Estádio III- Mancha nova apresentando forma oval alongada e coloração levemente parda de contornos mal definidos.

Estádio IV- Caracteriza-se pela paralização do crescimento micelial, aparecimento do halo amarelo em volta da mancha e início da esporulação do patógeno.

Estádio V- É a fase de mancha adulta. É oval alongada, com $12-15 \mathrm{~mm}$ de comprimento por $2-5 \mathrm{~mm}$ de largura. Apresenta uma depressão central de tecido seco e coloração cinza.

A partir do estádio de mancha, podem-se observar frutificações do fungo na forma de pontuações negras. 


\section{2- O patógeno}

O Mal-de-Sigatoka da bananeira é causado pelo fungo Mycosphaerella musicola Leach, forma perfeita ou sexuada de Pseudocercospora musae (Zimm) Deighton. Estão envolvidos portanto os esporos sexuados (ascósporos) e assexuados (conídios). Segundo Stover $(1964 ; 1972)$, as manchas de Sigatoka podem apresentar três estruturas bem definidas, facilmente observáveis após o clareamento da folha em lactofenol fervente. São elas: esporodóquio, peritécio e espermogônio. Os esporodóquios desenvolvem-se na câmara subestomática formando um corpo estromático marrom-escuro ou preto sobre o qual surgem conidióforos curtos, emergindo através da abertura do estômato. O comprimento varia de 21 a $102 \mu \mathrm{m}$, mas a média situa-se entre 50 e $64 \mu \mathrm{m}$. Os conídios formados nos esporodóquios são cilíndricos a obclavados, retos ou curvos, páleos a oliváceos, apresentando de 0-6 séptos, um vago hilo basal e dimensões variando de $20-109 \times 2,5-6 \mu \mathrm{m}$.

Os peritécios são em forma de frasco com uma parede espessa marromescura e ostíolo espesso bem definido, que emerge através do estômato. As dimensões variam de 51-86 x 35-77 $\mu \mathrm{m}$ com média de $65 \times 54 \mu \mathrm{m}$. Dentro dos peritécios encontram-se de 10-27 ascos, medindo $38 \times 11 \mu \mathrm{m}$. Os ascósporos produzidos são bicelulares, hialinos com dimensões variando de 13-14 x 4-6 $\mu \mathrm{m}$ sobre folhas e $20 \times 5 \mu \mathrm{m}$ sobre ágar.

O espermogônio é menor e de parede mais delgada do que o peritécio, apresentando formato de frasco ou altere. Dentro dos mesmos são produzidas espermácias incolores que, quando amadurecem, são liberadas sobre as folhas, sendo levadas por água de orvalho ou chuva. Quando em contato com peritécios jovens ocorre a fertilização e a consequente produção de ascósporos em estruturas denominadas sacos ou ascos, localizadas no interior dos peritécios. 
Apesar da literatura especializada sobre o mal-deSigatoka, referir-se à Mycosphaerella musicola como produtora de peritécios ela é classificada por Krugner \& Bacchi (1995) como pertencente à ordem Dothideales, onde a principal característica é a produção de ascos bitunicados, formados em tecido estromático denominado ascostroma.

O cultivo in vitro de $M$. musicola ( $P$. musae), visando a produção de esporos tem sido estudado por diversos autores. Calpouzos (1955), citado por Stover (1972), conseguiu a produção de conídios em meio de mycophil agar somente nos primeiros 3-4 dias de idade das colônias de alguns isolados, mas noutros havia setores das colônias com produção estável de conídios por quatro semanas. Observou-se, portanto, que havia uma mistura de micélio estéril (não produzia conídios) com micélio esporulante (produzia conídios). A obtenção de sub-culturas de setores esporulantes permitiu a produção estável de conídios sobre este meio, por 4-5 semanas, em regime de luz alternada de $12 \mathrm{~h}$, a $26^{\circ} \mathrm{C}$. A esporulação também ocorreu sobre os meios de milho e BDA. Em relação à temperatura , as de $20-25^{\circ} \mathrm{C}$, foram as que proporcionaram maior esporulação. O meio V8-ágar foi utilizado com sucesso por Fouré \& Lescot (1988), na produção de conídios por isolados de Mycosphaerella spp, patogênicos à bananeira. Albuquerque (1993) conseguiu produzir conídios a partir de isolados de P. musae em meios de BDA, soja e V8-ágar, com destaque para os dois últimos. A produção de inóculo foi feita mediante a semeadura de conídios sobre meio de soja e V8, seguindo-se à incubação sob luz contínua e temperatura de $25^{\circ} \mathrm{C}$. As maiores produções foram obtidas dos 14 aos 28 dias de incubação em meio V8 e, aos 14 dias em meio de soja.

Em relação às características da colônia, Meredith \& Lawrence (1970), estudando isolados provenientes das Filipinas, descrevem-nas como de crescimento muito lento sendo visíveis somente três dias após a incubação em 
meio de BDA. O diâmetro máximo obtido foi de $1,2 \mathrm{~cm}$ após 32 dias de incubação a $26^{\circ} \mathrm{C}$. Em V8 as colônias apresentaram coloração pálida a cinza com grande quantidade de micélio aéreo, mas ausência de esporulação. Notaram-se ainda a formação de corpos em forma de frasco 7-10 dias após a incubação, os quais foram associados a possíveis protoperitécios.

\section{3- Variabilidade em Mycosphaerella musicola}

As relações patógeno hospedeiro são marcadas por intimas relações geneticamente controladas, de tal modo que, variações genéticas na população de um dos componentes são acompanhadas por variações genéticas na população do outro componente (Camargo, 1995). Este mecanismo é conhecido como coevolução e significa que patógeno e hospedeiro estão em constante guerra evolutiva, ou seja, o lançamento de um mecanismo novo de defesa no hospedeiro (introdução de uma cultivar resistente, por exemplo) é normalmente acompanhado por uma subsequente evolução de um mecanismo complementar de ataque no patógeno ou vice-versa. Uma das condições essenciais para que a coevolução se processe é a existência de variabilidade genética tanto ao nível do patógeno como do hospedeiro. Coevolução implica em seleção e, uma vez que a seleção se processa, por meio da variabilidade genética, pode-se dizer que populações com alta variabilidade respondem melhor aos agentes seletivos, ou seja, adaptam-se melhor às mudanças do ambiente. A variabilidade genética em fungos pode ocorrer por mutação, o principal mecanismo gerador de novos genes, uma vez que permite a criação de novas seqüências nucleotídicas; por recombinação meiótica ou reprodução sexuada, destacando-se como o principal mecanismo amplificador da variabilidade; por recombinação parassexual em fungos imperfeitos, resultando na formação de recombinantes mitóticos; por 
herança citoplasmática, oriunda de genes presentes em organelas citoplasmáticas, os quais podem funcionar como determinantes de patogenicidade ou virulência, quando dois citoplasmas se fundem e ainda, pela formação de heterocárions.

Segundo Stakman \& Christensen (1960), dois dos maiores obstáculos para a produção e manutenção de variedades resistentes são a multiplicidade de requerimentos para uma satisfatória variedade e a multiplicidade de raças fisiológicas em vários patógenos. A variabilidade se agrava nos climas continentais devido a largas flutuações sazonais e intersazonais. A catalogação de todas as raças de um dado patógeno, provavelmente nunca poderá ser feita a um dado tempo, por dificuldade prática de amostragem de toda a variabilidade disponivel e por dificuldades de identificação. O autor acredita na existência de raças fisiológicas em todos os grupos de patógenos, incluindo bactérias, vírus, fungos e nematóides, destacando os seguintes requisitos básicos para a identificação de raças: a- selecionar apropriadas variedades indicadoras; bestabelecer classes com graus de infecção; c- determinar o grau de variabilidade fenotípica dentro de cada classe, incluindo sobreposição entre classes; d- prover facilidades físicas para padronização das condições ambientais. As diferenças surgidas podem ser apenas quantitativas, apenas qualitativas ou a combinação das duas. As diferenças apenas quantitativas são mais dificeis de serem classificadas. Porém, segundo Van Der Plank (1968), o mais comum é encontrar associado as diferenças qualitativas e quantitativas.

Um dos problemas correntes, frequentemente mencionado por melhoristas, é a falta de informação sobre a natureza das populações do patógeno. Este conhecimento é essencial para a condução do melhoramento genético por caminhos satisfatórios. Se nenhuma informação sobre a variabilidade das populações do patógeno está disponível, o melhoramento para resistência é dificultado. Assim, de acordo com Mourichon (1994), torna-se essencial a realização de um inventário das populações do parasita e, acima de tudo, avaliar 
sua diversidade intra-específica nas várias áreas produtoras de banana, usando marcadores patotípicos (variedades indicadoras) e seletivamente neutros (marcadores moleculares). $O$ estudo de variabilidade dentro da espécie $M$. musicola, é um assunto praticamente desconhecido. Existem, no entanto, suspeitas do surgimento de variantes do patógeno, como sugere Shepherd (1990), a despeito da alta suscetibilidade atualmente observada no Subgrupo Prata (AAB). Acredita-se que uma variante do patógeno tenha surgido na Região Nordeste do Brasil, evoluindo especificamente sobre variedades tradicionais como a Prata. A hipótese levantada, além de estar embasada no conhecimento do autor, leva em consideração a classificação apresentada por Simonds (1966), onde a variedade Prata $(\mathrm{AAB})$, aparece como medianamente resistente à Sigatoka. Atualmente os Subgrupos Prata e Cavendish apresentam comportamento similar, ou seja, são altamente suscetiveis. Fouré \& Lescot (1988) também fazem observações semelhantes sobre a presença em Camarões de uma cercosporiose de comportamento atípico. Observou-se no início de 1986, no Oeste e Centro deste país uma Cercospora patogênica não apenas sobre bananas do Subgrupo Cavendish (AAA), mas também sobre aquelas do Subgrupo Prata $(\mathrm{AAB})$, provocando sintomas idênticos também sobre Plátanos. Estudos anteriores, no entanto, evidenciavam a pouca suscetibilidade de bananeiras do Subgrupo Prata à Sigatoka Amarela e a resistência daquelas do Subgrupo Plátano. Segundo os autores, estudos de sintomatologia e laboratoriais confirmaram tratarse de M. musicola e, inoculações realizadas permitiram confirmar a agressividade do novo patótipo.

Pesquisas sobre diversidade genética têm sido conduzidas com isolados de M. musicola, de diferentes origens geográficas, utilizando "polimorfismo de comprimento de fragmentos de restrição" (RFLPs). O maior nível de diversidade foi encontrado em isolados do Sudeste da Ásia, região onde provavelmente a espécie originou. Em outras zonas epidêmicas os isolados formavam grupos 
geneticamente homogêneos, específicos de cada região: África, Ilhas do Pacífico e América Latina. A variabilidade comparativamente menor nestas regiões pode ser interpretada como uma limitada introdução de indivíduos em cada uma delas. A distância genética entre cada um desses grupos foi relativamente grande, embora os grupos formados pelas Ilhas do Pacífico e América Latina pareçam relacionados (Carlier, et al., 1993 ; Carlier et al., 1994, citados por Mourichon, 1994).

Algumas informações têm sıdo obtidas com Mycosphaerella fijiensis. Jacome \& Schuh (1993), avaliaram o comportamento de M. fijiensis var. difformis em relação à influência da temperatura sobre o crescimento e produção conidial in vitro, obtendo-se os seguntes resultados:

- interação significativa entre isolados e temperatura em relação ao crescimento; - variação na produção conidial entre os isolados, observando-se que a taxa de produção de conídios foi maior a $20^{\circ} \mathrm{C}$, reduzindo drasticamente a 25 e $30^{\circ} \mathrm{C}$; - variação no tamanho e forma das lesões causadas pelos diferentes isolados; - diferenças significativas em agressividade entre os isolados, considerando os parâmetros: severidade de doença, área abaixo da curva de progresso da doença, percentagem de folha necrosada e interação entre período de umidade foliar logo após a inoculação e isolado;

- o isolado tipo selvagem requeria maior período de umidade foliar do que os outros, os quais mostravam uma certa adaptação a ambientes secos.

Segundo os autores as diferenças em agressividade observadas entre os isolados podem estar associadas a aumento na eficiência da infecção e/ou aumento no tamanho da lesão. As observações foram feitas inoculando apenas uma variedade de banana em combinação com três períodos de umidade foliar logo após a inoculação $(0,9$ e $18 \mathrm{~h})$. 
A variabilidade patogênica de diversos isolados de $M$. fijiensis de diversos países e localidades, tem sido avaliada sobre plantas jovens de um conjunto padrão de cultivares e espécies de Musa. Segundo Mourichon(1994), os primeiros resultados, obtidos na Nova Zelandia por Fullerton \& Olsen (1993), indicam que os isolados apresentam consistentes, mas diferentes padrões de patogenicidade sobre o conjunto de hospedeiras. Algumas cultivares e espécies foram consistentemente suscetíveis a todos os isolados, enquanto outras foram resistentes a alguns mas suscetíveis a outros, caracterizando uma interação diferencial. Segundo Mourichon (1994), a diversidade genética em M. fijiensis é resultante da reprodução sexual e, acima de tudo, da natureza heterotálica claramente demonstrada nesta espécie (Stover,1963). A ocorrência de anastomose de hifas e da heterocariose em Mycosphaerella foi demonstrada in vitro por Monnier (1986), motivado por questionamentos surgidos após a descrição de $M$. fijiensis var. difformis, que apresentava características tanto de M. musicola como de $M$. fijiensis. Observou-se que a anastomose ocorre com maior frequência entre isolados da mesma espécie, mas que também ocorre entre isolados de espécies diferentes. A anastomose de hifas conforme observada pode ser a origem de muitos fenômenos de troca de informações genéticas. Os heterocárions, observados entre $M$. musicola e $M$. fijiensis, não se mostraram estáveis, mas isto não exclui a possibilidade de ocorrência, no campo, de hibridações verdadeiras entre espécies diferentes pelas vias sexuais.

\section{4- Resistência do gênero Musa à Mycosphaerella}

\subsection{1- Aspectos gerais da resistência}

Resistência é definida por Daly (1976) como a capacidade de uma planta prevenir ou restringir o estabelecimento e subsequente atividades de um patógeno 
potencial. Fry (1982) diz que resistência é uma característica da planta, que permite suprimir o desenvolvimento do patógeno e da doença. Nelson (1973) define como uma ativa e dinâmica resposta do hospedeiro ao parasita, caracterizando duas formas principais de resistência:

1- Resistência ao estabelecimento do parasita, restringindo o sítio de infecção e o processo de infeç̧ão. Neste caso ela é chamada de hipersensibilidade, resistência específica, resistência não uniforme, resistência vertical ou resistência de gene maior.

2- Resistência à colonização e crescimento do parasita subsequente à infecção. Neste caso o processo de infecção, culminando com a reprodução é completado. Este tipo de resistência é referida como resistência de campo, resistência generalizada, não específica, parcial, uniforme, horizontal, poli ou multigênica, resistência de gene menor.

Os termos vertical e horizontal foram propostos por Van der Plank (1963; 1968). O primeiro caracteriza a ocorrência de interação diferencial entre patógeno e hospedeiro, quando isolados ou raças do patógeno são inoculados sobre variedades do hospedeiro. Ocorrendo a interação, diz-se que os isolados variam em virulência. $O$ segundo termo caracteriza a ausência de interação diferencial entre hospedeiro e patógeno, caracterizando a variação do isolado em agressividade. A resistência horizontal caracteristicamente retarda o progresso da epidemia pela redução da esporulação do patógeno, redução da infeç̧ão e aumento do período latente. O termo horizontal é também referido por Eskes (1980) como resistência de planta adulta, resistência estável ou duradora. Alguns autores discordam dos termos horizontal e vertical criados por Van der Plank (1963), como é o caso de Nelson (1973). Johnson (1981) prefere utilizar o termo durável ou duradoura, definindo-a como aquela resistência que permanece efetiva, enquanto uma variedade continuar sendo largamente cultivada, não implicando em que a mesma permaneça indefinidamente efetiva. A resistência 
horizontal, de acordo com Eskes (1980), foi originalmente considerada como não completa, baseando-se em mecanismos que dificultam parcialmente o desenvolvimento do patógeno nos tecidos do hospedeiro. Atualmente, existem dados que indicam que a resistência horizontal pode ter uma expressão de quase imunidade, como observado por Simons (1972), na interação Puccinia striiformis e trigo ou uma reação de resistência similar ao da resistência vertical com herança poligênica no patossistema batata/Phytophthora infestans (Thurston,1971). De acordo com Robinson (1976), a resistência vertical geralmente equivale ao conceito gene-a-gene de Flor (1942), envolvendo mecanismos de herança governados por genes isolados, sendo facilmente manipulada em programas de melhoramento. Por esta razão é, muitas vezes, preferida em vez da resistência horizontal que, geralmente envolve mecanismos cuja herança é governada por vários genes, tornando-se difícil a manipulação genética. Porém, enquanto a resistência vertical pode oferecer o controle completo de uma enfermidade, ela é também passível de ser quebrada. Portanto resistência vertical tem pouca probabilidade de sucesso em culturas perenes ou em culturas dificeis de serem trabalhadas pelo melhoramento genético.

\subsection{2- Aspectos específicos da resistência}

\subsubsection{1- Avaliações a nível de campo}

Poucos são os trabalhos avaliando resistência do gênero Musa à $M$. musicola. Vakili (1968) avaliou a resposta de espécies de Musa acuminata e variedades comestíveis à infecção por M. musicola, observando os seguintes dados: número de dias entre o desenrolamento da folha e o aparecimento de estrias amarelas (período de incubação); número de dias entre a fase de estrias e o aparecimento de lesões maduras; número total de manchas maduras por planta ; 
número da folha mais jovem com manchas maduras e número de esporodóquios formados sobre diferentes tipos de lesões. Concluiu que entre os acessos de $M$. acuminata havia uma gradação na resposta à infecção, permitindo classificá-los em altamente resistentes, resistentes, parcialmente resistentes, suscetíveis e altamente suscetíveis.

Parâmetros como percentagem de manchamento de folhas, número médio da folha mais jovem manchada e número médio de folhas verdes foram utilizados por Shillingford (1974) na avaliação de variedades em relação à Sigatoka. A resposta variou com a estação do ano e o local de plantio. Em condições de baixa pressão de inóculo, as cultivares Robusta e Valery foram similarmente afetadas. Em outro local, porém, 'Valery' foi menos afetada de que 'Robusta'. Observouse, neste caso, que cultivares de constituição genômica semelhante, como é o caso dessas duas, podem mostrar diferenças na quantidade de doença, se a taxa de emergência de folhas for diferente. Sugere-se que fatores como altura de planta, taxa de emissão de folhas, comprimento da folha etc, podem afetar a aerodinâmica da planta, a impactação do esporo e, consequentemente, o aumento de doença. Parece haver dois componentes da resistência à Sigatoka e o maior deles é geneticamente controlado e afeta a latência da infecção. Já o componente menor é um tipo de resistência de campo, baseada numa maior velocidade de produção de folhas pela cultivar, possibilitando a manutenção de uma maior área foliar verde.

Trabalhos mais recentes, no entanto, envolvem principalmente a avaliação do comportamento de banana e plátanos em relação à $M$. fijiensis. Dentre estes destacam-se os trabalhos de Fouré (1982); Fouré et al. (1984); Fouré (1985); Galindo et al. (1990) e Escalant (1993), nos quais têm sido utilizados parâmetros como formação de conidióforos e conídios, formação de peritécios e ascósporos determinando-se o número por $\mathrm{mm}^{2}$; período de incubação, tempo de evolução da lesão, que corresponde ao período decorrido entre o aparecimento dos 
primeiros sintomas e a formação de lesões necróticas, determinação da folha mais jovem necrosada, folha mais jovem infectada e rítmo de emissão de folhas.

Segundo Fouré (1985), não há correlação entre a duração do período de incubação e a resistência das cultivares à Sigatoka negra. O mesmo destaca ainda, que o período de evolução das lesões, embora seja influenciado pelas condições climáticas, juntamente com o número de folhas funcionais na época da colheita traduzem perfeitamente o grau de sensibilidade de uma cultivar.

\subsubsection{2- Avaliações a nível de casa de vegetação}

Estudos conduzidos por Goos \& Tschirch (1963), trabalhando com $M$. musicola em condições de casa-de-vegetação, demonstraram a importância da umidade e da flutuação das condições úmido/seco, para o desenvolvimento dos sintomas da Sigatoka amarela em bananeira. Observou-se que tanto a penetração como o desenvolvimento de sintomas são favorecidos pela flutuação úmido/seco no ambiente. A inoculação seguida por 2 a 4 dias de contínua umidade e, posteriormente, $16-18 \mathrm{~h}$ de umidade noturna e $6-8 \mathrm{~h}$ de baixa umidade durante o dia, propiciavam o desenvolvimento de múltiplas lesões dentro de 25-28 dias após a inoculação e, severa necrose, com morte das folhas infectadas dentro de 35-42 dias.

Segundo Mourichon (1994), procedimentos de inoculação artificial, sob condições controladas, devem ser capazes de avaliar tanto a resistência qualitativa quanto a quantitativa, usando um conjunto de isolados que representem a diversidade total das populações do patógeno em termos de "virulência" e "agressividade". O autor acredita que os procedimentos para avaliar a resistência qualitativa ou vertical são simples e não requerem rigoroso controle de inóculo e condições de incubação. Por outro lado, para resistência quantitativa ou horizontal, nível de inóculo, idade do hospedeiro, condições de incubação e pós 
incubação, devem ser estritamente controlados. A inoculação artificial não deve ser severa a ponto de superestimar a capacidade de um agente para causar doença ou subestimar a resistência do hospedeiro. A maioria das tentativas de avaliação à Sigatoka em condições controladas têm sido realizadas com $M$. fijiensis, agente causal da Sigatoka negra. Duas técnicas, testadas por Jacome \& Schuh (1993a), utilizaram a inoculação com suspensão de conídios produzidos artificialmente e o sistema de descarga direta de ascósporos a partir de lesões maduras. Ambas aplicavam os esporos em uma superfície delimitada na face inferior da folha. A inoculação de conídios produzidos in vitro, mostrou-se mais eficiente. $\mathrm{Na}$ avaliação da intensidade de doença foi utilizada uma escala diagramática com dez graus de severidade $(0,5 ; 1,0 ; 3,0 ; 5,0 ; 7,5 ; 10 ; 15 ; 20 ; 30$ e 40\% de área foliar afetada). As observações realizadas entre dois isolados mostraram que houve diferença no progresso da doença e no número de lesões obtidas. Notouse, por exemplo, que na folha número 1, o isolado SB apresentou maior severidade final de doença e maior taxa aparente de infecção $r$, de acordo com a equação logística.

A severidade da Sigatoka negra sobre folhas infectadas por conídios ou ascósporos é influenciada pela temperatura e pela duração do período de umidade foliar após a inoculação (Jacome \& Schuh, 1992). A infecção com ascósporos só ocorreu quando urn filme de água estava presente sobre a folha. Já a infecção com conídios foi observada em período de exposição a alta umidade variando de 0 18h. O período de incubação foi de 14 dias em folhas submetidas a $18 \mathrm{~h}$ de umidade após a inoculação. A severidade da doença aumentava com o aumento do período de umidade foliar. A faixa ótima de temperatura foi de $25-28^{\circ} \mathrm{C}$. Folhas mais velhas mostravam-se mais conducivas ao desenvolvimento da doença. As plantas utilizadas apresentavam-se com seis folhas abertas, nas quais era delimitada uma área de $7 \mathrm{~cm} \times 12 \mathrm{~cm}$, sobre a qual pulverizou-se $1 \mathrm{ml} \mathrm{da}$ 
suspensão conidial com $10^{5}$ conídios $/ \mathrm{ml}$. Após a inoculação as plantas permaneciam no laboratório por 30-45 minutos para secagem, sendo posteriormente submetidas aos tratamentos combinando tempo de exposição a alta umidade e temperatura (umidade: $0 ; 9$ e $18 \mathrm{~h}$; temperatura: $22 ; 25 ; 28$ e $31^{\circ}$ C). $\mathrm{Na}$ avaliação do experimento foram considerados os parâmetros: severidade da doença ; número de lesões ; percentagem de tecido necrosado e área abaixo da curva de progresso da doença.

\subsubsection{3- Características da resistência}

Embora a busca da resistência à Sigatoka, tanto a amarela quanto a negra, tem sido objeto de antigos programas de melhoramento (na Jamaica, há mais de 40 anos; em Honduras há mais de 30 anos) pouco se conhece acerca da herança da resistência. Apesar das dificuldades apresentadas pelo melhoramento genético de Musa, é essencial que a resistência a ser utilizada nos programas seja de natureza durável. Diante disto, é importante conhecer a natureza genética da resistência dos parentais e, em particular, se ela é controlada por um único gene ou genes maiores (resistência especifica/resistência vertical) ou por um número de genes menores com efeito aditivo (resistência geral/resistência horizontal) (Fullerton \& Olsen, 1993). O assunto é enfocado por alguns autores apenas de forma sutil e/ou especulativa, até porque não têm sido desenvolvidos trabalhos que suportem uma discussão mais aprofundada sobre o mesmo. Segundo Shepherd (1990), a base genética da resistência à Sigatoka amarela não é simples. Tem sido mencionada a possibilidade de que genes recessivos sejam parcialmente responsáveis pela resistência de Musa acuminata selvagem. Além do mais, apesar do baixo número de cruzamentos observados, parentais altamente suscetíveis podem gerar híbridos resistentes. Em familias com marcada segregação, raramente é possivel discriminar entre classes resistentes e suscetíveis sem o 
aparecimento de plantas com reações intermediárias, as quais são difíceis de classificar. Até mesmo dentro das classes fenotípicas existem variações entre indivíduos. Em suma, as conjecturas mais comuns são de que muitos genes estão envolvidos na resistência, alguns com efeito relativamente maior e muitos outros com ação menor. Shillingford (1974), avaliando as variedades triplóides AAA, Valery e Robusta, observou que cultivares de constituição genômica semelhante, como neste caso, podem diferir na quantidade de doença, dependendo da taxa de emergência de folhas. Segundo o autor, parece haver dois componentes na resistência à Sigatoka. O maior deles é geneticamente controlado e afeta a latência da doença, enquanto o menor é um tipo de resistência de campo baseada numa maior velocidade de produção de folhas, possibilitando a permanência de uma maior área foliar verde.

Com relação à Sigatoka negra (M. fijiensis), Fouré (1993) cita, como interessante, o fato de que a alta resistência tem ocorrido somente em genótipos AA e AAA. Segundo este autor, na avaliação de progênies autofecundadas de M53 (híbrido diplóide AA), observa-se que, embora a alta resistência seja mascarada nos parentais, ela foi dominante na geração $F 1$ e que da interação entre alta resistência e resistência parcial a última foi dominante.

A maioria dos trabalhos que avaliam a resistência de genótipos de bananeira à Sigatoka amarela e/ou negra têm se restringido a agrupá-los em classes fenotípicas. Simmonds (1966) reconheceu quatro classes de reação: altamente suscetível; ligeiramente suscetível; resistente e altamente resistente. Nas variedades resistentes, onde apareciam poucas manchas sobre as folhas mais velhas, acredita-se que esteja envolvido um efeito de latência. Vakili (1968), avaliando a resistência à Sigatoka amarela em espécies de Musa e variedades comestíveis, classificou-as em altamente resistentes, resistentes, parcialmente resistentes, suscetíveis e altamente suscetíveis. Com base na análise visual das folhas inoculadas, Jones (1995) classificou o germoplasma de Musa avaliado para 
resistência à Sigatoka amarela em: Extremamente resistente (ER)- quando ocorria apenas formação de estrias necróticas ou ausência de sintomas visíveis; Parcialmente Resistentes (PR)- quando ocorria formação de algumas lesões necróticas, mas sem o desenvolvimento de manchas maduras; Suscetível (S)quando ocorria o desenvolvimento de numerosas manchas maduras. A alta resistência foi relacionada a uma resposta hipersensível. Segundo o autor, a resistência parcial é possivelmente controlada por fatores multigênicos, podendo ser de maior valor do que a resistência baseada numa resposta hipersensível, a qual, se for controlada por um único gem, pode ser quebrada por uma simples mutação do patógeno.

Semelhantemente, as reações à Sigatoka negra também variam de alta suscetibilidade à resistência, tanto entre como dentro dos grupos genômicos. Meredith \& Lawrence (1970) avaliaram a suscetibilidade de cultivares de banana à $M$. fijiensis e, com base em escores arbitrários, agrupou-as em altamente resistentes, moderadamente suscetíveis e ligeiramente suscetíveis. Quatro fenótipos são caracterizados por Fouré (1993), nas reações de cultivares de banana com base em estimativas do período de incubação; desenvolvimento da lesão do estádio I até o VI; necrose devido à alta densidade de manchas e intensidade de esporulação sexual e assexual:

\section{Fenótipo I}

Alta resistência- os sintoma da doença são paralizados no estádio I ou II (estrias) e não há esporulação sexual ou assexual. A reação apresentada por estes genótipos lembra a hipersensibilidade, que em muitos casos é mono ou oligogênica. Alta resistência é provavelmente um fenótipo qualitativo, controlado por um pequeno número de genes. Embora possa parecer desejável, é facilmente superado pelo patógeno, sendo por isso mesmo menos durável.

\section{Fenótipo II}


Resistência Parcial- nestas plantas, ocorre baixo desenvolvimento da doença do estádio I até necrose, propiciando um alto número de folhas funcionais na colheita. Ocorre esporulação sexual e assexual. É provavelmente um caráter quantitativo associado a vários genes (resistência horizontal).

\section{Fenótipo III}

Suscetibilidade- o desenvolvimento do estádio I até necrose é normal e rápido. A esporulação (sexual e assexual) pode atingir niveis altos se as condições climáticas forem favoráveis a um rápido desenvolvimento da doença. Poucas folhas funcionais estão presentes na época da colheita.

\section{Fenótipo IV}

Alta suscetibilidade- a doença progride rapidamente para o estádio necrótico e pouca ou nenhuma folha funcional está presente na época da colheita.

$\mathrm{O}$ autor acredita que resistência parcial, suscetibilidade e alta suscetibilidade são provavelmente diferentes classes de um fenótipo quantitativo, controlado por vários genes. As reações podem portanto serem divididas em dois tipos principais:

- Fenótipo de alta resistência (HR)

- Fenótipo de resistência parcial (PR), compreendendo diferentes níveis de reação da alta resistência parcial à suscetibilidade (suscetível e altamente suscetível).

Estudos bioquímicos e citológicos, envolvendo interações hospedeiroparasita em cultivares suscetíveis, com resistência parcial e alta resistência, inoculadas com Cercospora fijiensis, foram conduzidos por Beveraggi et al. (1993) em comparação com o tecido sadio. Foram observadas duas interações distintas. A resistência parcial parece estar ligada a um composto fenólico presente em baixo nivel na interação altamente resistente. No hospedeiro altamente resistente, por sua vez, um mecanismo de defesa é ativado após a penetração estomatal, o qual induz uma rápida morte do parasita e das células do hospedeiro localizadas além da hifa. A reação é provavelmente induzida por 
elicitores endógenos liberados pelo parasita ou nos estádios iniciais de modificações das células hospedeiras. A descrição é semelhante à reação de hipersensibilidade, que também envolve um grande número de células.

\subsection{3- Resistência induzida}

Entende-se por indução de resistência em plantas, indução de proteção ou imunidade adquirida ao fenômeno de ativação de mecanismos de defesa, que estão latentes nas plantas, mediante o tratamento das mesmas com agentes bióticos ou abióticos. Entre os agentes bióticos podem ser utilizados microrganismos viáveis ou inativados e entre os abióticos destacam-se os metais pesados. Sabe-se que a proteção induzida é dependente de um intervalo de tempo entre o tratamento indutor e o desafiador, indicando assim a importância de alterações metabólicas na planta no sentido de síntese e/ou acúmulo de substâncias, as quais passarão a atuar local ou sistemicamente na proteção da planta, cujos mecanismos foram ativados (Pascholati \& Leite, 1995). Um caso histórico de indução de proteção com agentes bióticos é citado por Daly (1968), embora o assunto não tenha sido referido como resistência induzida. Observou-se que tubérculos de batata portadores do gem R1 de resistência a Phytophthora infestans quando inoculados com a raça 0 , desenvolvia resistência não só à raça 0 , mas também à 1 , mediante acumulação de substâncias tóxicas.

A indução de resistência é um assunto completamente novo na cultura da bananeira. A introdução do mesmo neste trabalho, surgiu na avaliação da variabilidade dentro da espécie M. musicola (P. musae). Duas situações diferentes conduziram o raciocínio para a hipótese de resistência sistêmica induzida. No primeiro caso, plantas suscetíveis manifestando interação incompatível isoladocultivar, comportavam-se como resistentes em inoculações posteriores. Num 
segundo caso, plantas suscetíveis, inoculadas com isolados compatíveis, mas mantidas em ambiente desfavorável ao desenvolvimento da doença, também se comportavam como resistentes em inoculações posteriores. Diante de tais evidências, a hipótese de resistência induzida tornou-se mais forte. A habilidade de uma planta responder a uma infecção é determinada por características genéticas tanto do hospedeiro como do patógeno. Alguns mecanismos de resistência são específicos para cultivares e certos strains do patógeno. Nestes casos, os genes de resistência do hospedeiro reconhecem moléculas derivadas do patógeno, resultantes da expressão dos, assim chamados, genes de avirulência, os quais frequentemente produzem um sinal em cascata, levando à rápida morte das células do hospedeiro. Tais relações gene-a-gene são parte da resistência vertical da planta, que usualmente confere alta resistência, mas muito específica. Ao contrário, a resistência horizontal apresenta um amplo espectro de controle de doenças. Os mecanismos envolvidos na mesma incluem barreiras físicas préformadas (parede celular lignificada; ceras; acumulação de metabólitos microbianos) como também mecanismos induzíveis (Kessmann et al.,1994). Nesta revisão dar-se-á ênfase à indução de resistência por agentes bióticos em que um patógeno induz proteção contra ele próprio.

Vários trabalhos têm demonstrado a proteção de plantas contra patógenos fúngicos mediante inoculações prévias com o próprio patógeno. É o caso, por exemplo, da proteção de pepino contra C. lagenarium (Kuc \& Richmond, 1977 ; Dalisay \& Kuc, 1995). Estes autores destacam uma proteção sistêmica em pepino, quando o mesmo é submetido a uma prévia inoculação das folhas cotiledonares ou a primeira folha verdadeira com $C$. lagenarum. Observou-se que havia uma correlação direta entre a concentração de esporos utilizada na indução e 0 aumento e duração da proteção; que uma proteção induzida por seis semanas, progressivamente, era reduzida durante este tempo e que a remoção da folha inoculada, para induzir a proteção, provocava uma progressiva redução da 
resistência adquirida, maior do que quando a mesma permanecia ligada à planta. Segundo Kuc \& Richmond (1977), os resultados indicam que a proteção é realçada em cultivares resistentes e não é limitada a uma única raça do fungo. $\mathrm{O}$ desenvolvimento de sintomas sobre cultivares resistentes não protegidas e suscetíveis protegidas foram similares, havendo retardamento no aparecimento de sintomas, redução no número e tamanho das lesões e formação de lesões cloróticas com reduzida necrose. A possibilidade de se aumentar a proteção com aumentos na concentração do inóculo protetor, sugere que a injúria do tecido não é o único determinante da proteção. A natureza sistêmica da resistência induzida em pepino sugere a produção de um sinal durante os primeiros sete dias após a inoculação da folha 1 (Dalisay \& Kuc, 1995). Este sinal seria translocado para as folhas superiores nas quais a resistência é elicitada. O sinal induz o aparecimento de várias respostas não específicas na planta, as quais podem funcionar na defesa da planta contra patógenos. Em pepino a resposta contra $C$. lagenarum inclui aumento na atividade da peroxidase e quitinase na folha inoculada e naquelas surgidas posteriormente. Esta observação suporta a hipótese de que um sinal translocável é responsável pelo aumento da atividade da quitinase e peroxidase na planta inteira. Ainda em pepino tem sido relatada a resistência sistêmica induzida por rhizobactéria promotora de crescimento, contra a antracnose causada por Colletotrichum orbiculare (Liu et al., 1995) e contra a mancha angular da folha causada por Pseudomonas syringae pv. lachrymans.

A indução de resistência em cevada, mediante inoculação prévia de raças compatíveis e incompatíveis de Erysiphe graminis f. sp. hordei, foi reportada por Hwang \& Heitefus (1982), com base na redução do número de colônias e inibição do crescimento de hifas. Observou-se que a indução de resistência ocorreu tanto com a inoculação prévia da raça compatível nas folhas 1 e 2 , como quando se inoculou a raça incompatível . Por outro lado, a proteção induzida pela raça incompatível foi maior do que a induzida pela raça compatível. Isto sugere que 
resistência induzida contra o oídio pode ser variável, dependendo do genótipo do patógeno utilizado como indutor.

Em feijão, a resistência induzida contra antracnose foi observada em hipocótilos estiolados, inoculando-os com não patógenos como Helminthosporium carbonum (raça 1) ou Alternaria sp, ocorrendo resposta hipersensivel 24-36h após a inoculação. Resposta similar, foi também observada 60-72h após a inoculação de uma raça não patogênica de Colletotrichum lindemuthianum agente causal da antracnose (Rahe et al.,1969). Observou-se que a resposta hipersensível tornava o tecido inoculado resistente a raças patogênicas de $C$. lindemuthianum. Quando se utilizou $H$. carbonum ou Alternaria sp como indutores, os sintomas foram reduzidos para cerca de $50 \%$ do controle com desafio a 0 h e para 5-25\%, quando o desafio ocorreu 24-96h após a indução. Quando entretanto, a raça não patogênica de $C$. lindemuthianum foi utilizada como indutora observou-se total proteção 24-96h após a inoculação de indução.

Em tomate, Fuchs et al. (1997) testaram a capacidade de formas não patogênicas de Fusarium oxysporum induzir resistência à murcha. As formas patogênicas e não patogênicas foram separadas e os ensaios foram conduzidos em condições hidropônicas ou em solo autoclavado. A forma não patogênica protegeu o tomate contra a murcha de Fusarium em todas as situações. Nas plantas inoculadas com a forma não patogênica havia aumento na atividade de quitinase, B-1,3-glucanase e B-1,4-glucosidase, confirmando a habilidade da forma não patogênica em induzir resistência em tomate. Em fumo foi relatada por Mcintyre \& Miller (1978), uma proteção localizada contra Phytophthora parasitica var. nicotianae, mediante inoculação prévia de uma raça não patogênica.

Um aspecto interessante, relatado por Heller \& Gessler (1986), mostra que a infecç̧ão em folhas superiores de tomate por $P$. infestans, seguido por um período desfavorável ao desenvolvimento da doença, aumenta a resistência geral 
da planta contra o patógeno. Neste caso, ocorre uma indução de resistência a uma segunda infecção nas folhas superiores, expressa na forma de lesões nitidamente definidas, de menor tamanho e com supressão da esporulação do patógeno. Havia um retardamento e redução na penetração do patógeno na epiderme e, subsequentemente, na colonização do mesófilo, pela formação de papilas nas células epidérmicas e reações tipo hipersensíveis nas células do mesófilo.

Em milho, a inoculação da raça 2 de $H$. carbonum (não patogênica), pelo menos $10 \mathrm{~h}$ antes da inoculação da raça 1 (patogênica), prevenia $\mathrm{o}$ desenvolvimento de largas lesões típicas de reação suscetível. A formação de apressório, penetração e crescimento de hifas do patógeno foram reduzidos. Entretanto, a adição de H. C.- toxina (toxina específica produzida pela raça 1 do patógeno) na inoculação desafiadora abolia a resistência induzida pela raça 2 (Cantone \& Dunkle, 1990).

Quanto aos mecanismos que envolvem a resistência sistêmica adquirida, Kessmann et al. (1994) relatam que as plantas freqüentemente respondem, no sítio de tentativa de infecção, com a morte localizada de células (resposta hipersensível), seguida por várias outras respostas adicionais, que incluem: fornação de fitoalexinas e calose, lignificação e espessamento da parede celular. Em fumo, a infecção por TMV leva à acumulação de proteinas-RP e em pepino a atividade de quitinase é sistemicamente induzida. 


\section{CAPÍTULO I}

\section{3- VARIABILIDADE PATOGÊNICA EM Mycosphaerella musicola}

\section{RESUMO}

Mycosphaerella musicola(=Pseudocercospora musae), é o agente causal da Sigatoka amarela, a mais importante doença da bananeira no Brasil. A variabilidade do patógeno no que tange à interação hospedeiro-parasita é um assunto ainda desconhecido dentro da espécie, apesar da importância desta informação para o melhoramento genético visando resistência à doença. $O$ objetivo deste trabalho foi avaliar a variabilidade patogênica de diversos isolados de $M$. musicola, submetendo-os à inoculação em um conjunto de variedades diferenciadoras.Desta forma, coletaram-se trinta e quatro isolados oriundos de variedades e regiões diferentes, os quais foram multiplicados in vitro e submetidos, primeiramente, a testes de patogenicidade sobre as variedades Nanicão, Prata Anã e Pacovan. Posteriormente, um grupo de dezoito isolados foi submetido à avaliação, mediante inoculação por aspersão na face inferior das folhas 1 e 2 , com uma suspensão contendo $4.10^{4}$ conídios $/ \mathrm{ml}$, sobre as variedades Prata Anã, Pacovan, Nanicão, Terra, Mysore, Yangambi e Pioneira. A incubação, pós-inoculação, foi feita em telado com 3-4h diárias de irrigação por aspersão, normalmente das 16 às $20 \mathrm{~h}$. Foram coletados os dados de freqüência de lesão por 
$50 \mathrm{~cm}^{2}$, aos 38 dias após a inoculação e de severidade aos 55 dias. Observou-se uma interação diferencial altamente significativa em relação aos dois parâmetros

avaliados, elegendo-se quinze isolad $s$ s diferentes entre os dezoito avaliados, mostrando assim uma alta variabilidade patogênica dentro da espécie.

\title{
PATHOGENIC VARIABILITY IN Mycosphaerella musicola
}

\begin{abstract}
Mycosphaerella musicola (=Pseudocercospora musae) is the causal agent of yellow Sigatoka, the most important banana disease in Brazil. The variability of the pathogen withrespect to the host-parasite interaction is yet na unknown subject within the species, regardless the importance of this information for breeding programs for resistance. The objectif of this paper was to evaluate the variability in patogenicity of severalisolates of the pathogen which were inoculated on a set of differential varieties. Thinty four isolates from different regions and varieties were multiplied in vtro and tested against varieties Nanicão, Prata Anã e Pacovan. Subsequently, a set of 18 isolates was evaluated by spraying the abaxial surface of leaves 1 and 2 of varieties Prata Anã, Pacovan, Nanicão, Terra, Mysore, Yangambi and Pioneira with a suspension of $4.10^{4}$ conidia/ml. Inoculated plants were hept under a shade screen and sprinkeed daily during 3-4h after 4 p.m. Data on number of lesions by $50 \mathrm{~cm}^{2}$ and severity were colected 38 and 55 days after inoculation, respectively. A highly significant differential interaction was found in relation to both parametes evaluated, 15 isolates being differentiated among the 18 tested. A high variability in patogenicity was detected within the pathogen population.
\end{abstract}




\section{1- INTRODUÇÃO}

Mycosphaerella musicola Leach (forma anamórfica Pseudocercospora musae (Zimm) Deighton) é o agente causal da mais importante doença da bananeira, que ocorre no Brasil, conhecida como mal-de-Sigatoka, Sigatoka amarela ou ainda cercosporiose. É um patógeno incitador de manchas foliares, provocando intenso desfolhamento nas plantas, causado pela morte prematura das folhas. Segundo Meredith(1970), as manchas de sigatoka podem apresentar três estruturas do potógeno: esporodóquio, peritécio (pseudotécio) e espermogônio. Os conídios, formados nos esporodóquios, são cilíndricos a obclavados, retos ou curvos, páleos a oliváceos, apresentando de 0-6 séptos, um vago hilum basal e dimensões variando de 20-109 $\mu \mathrm{m} \times 2,5-6 \mu \mathrm{m}$.

Em meio de cultura, as colônias apresentam, segundo Meredith \& Lawrence (1970), crescimento muito lento sendo visíveis somente três dias após a inoculação em meio de $\mathrm{BDA}$ (batata, dextrose e ágar). $\mathrm{O}$ diâmetro máximo obtido foi de $1,2 \mathrm{~cm}$ após 32 dias de incubação a $26^{\circ} \mathrm{C}$. Em meio V8(100ml de suco v8, $15 \mathrm{~g}$ de ágar e $2 \mathrm{~g}$ de $\mathrm{CaCO}_{3}$ e $900 \mathrm{ml}$ de água destilada) elas apresentam coloração pálida a cinza com grande quantidade de micélio aéreo, mas ausência de esporulação. Notaram-se a formação de corpos em forma de frascos 7-10 dias após inoculação, os quais estávam associados a possíveis protoperitécios.

A variabilidade do patógeno, principalmente no que tange à interação hospedeiro-parasita é um assunto praticamente desconhecido dentro da espécie M.musicola, apesar da importância do assunto, quando se trata de melhoramento genético visando resistência à doença. O que existem são apenas suspeitas como a levantada por Shepherd (1990), a despeito da alta suscetibilidade atualmente observada em variedades do Subgrupo Prata (AAB). Acredita-se que uma variante do patógeno tenha surgido na região Nordeste do Brasil, evoluindo 
especificamente sobre variedades tradicionais como a Prata. A hipótese leva em conta, além da experiência do autor, a classificação apresentada por Simmonds (1966), onde a variedade Prata é tida como medianamente resistente à Sigatoka amarela. Outra observação é feita por Fouré \& Lescot (1988) sobre a presença, em Camarões, de urna cercosporiose de comportamento atípico, causando problemas sobre bananas do Subgrupo Prata, como também, sobre Plátanos.

A diversidade genética dentro da espécie tem sido avaliada com o uso de marcadores moleculares tipo "Polimorfismo de Comprimento de Fragmentos de Restrição"(RFLP) (Carlier et al. 1993; Carlier et al. 1994). A maior diversidade foi encontrada em isolados do Sudeste Asiático, de onde, provavelmente a espécie originou. Em outras áreas corno Ilhas do Pacifico, África e América Latina a variabilidade foi comparativamente menor, sugerindo uma limitada introdução de indivíduos.

Dentro da espécie $M$. fijiensis, a variabilidade patogênica de diversos isolados sobre um conjunto de diferenciadoras tem indicado a existência de urna interação diferencial (Fullerton \& Olsen, 1993). Segundo Mourichon (1994); a diversidade genética nesta espécie resulta da reprodução sexual e, acima de tudo, da natureza heterotálica, claramente demonstrada nesta espécie (Stover, 1963). Outras fontes de variação dentro do gênero Mycosphaerella foram demonstradas in vitro por Monnier (1986) e incluem anastomose de hifas e heterocariose.

O objetivo deste trabalho foi avaliar a variabilidade patogênica de diversos isolados de M. musicola sobre um conjunto de variedades diferenciadoras.

\section{2- MATERIAL E MÉTODOS}

O ensaio foi conduzido no laboratório e telado rústico do departamento de fitopatologia da ESALQ / USP, em Piracicaba, SP, no período de março de 1996 a abril de 1997, passando pelas seguintes etapas: 


\subsection{1- Obtenção dos isolados}

Os isolados foram obtidos a partir de cultivares e de regiões diferentes. Pedaços de folhas contendo lesões, de preferencia nos estádios IV e V de acordo com as descrições propostas por Brun (1963), citado por Stover (1972), foram coletados e trazidos para o laboratório, onde uma amostra era lavada em água destilada, desinfestada em hipoclorito de sódio $1 \%$, novamente lavada em água estéril e colocada em câmara úmida numa placa de petri por $48 \mathrm{~h}$, para induzir a esporulação. Passado este período as frações de folhas eram examinadas em microscópio estereoscópico para indentificação dos esporodóquios formados. Utilizando-se de um estilete ponta fina, flambado, os conídios eram transferidos diretamente para meio de BDA ou V8. Outra alternativa também utilizada, principalmente para amostras recebidas pelo correio, as quais chegavam quase sempre esporuladas e contaminadas, foi selecionar as lesões, retirar pequenas frações das mesmas, submetê-las aos procedimentos normais de isolamento, secálas em papel filtro e transferir para meio de ágar-água $2 \%$. Após o aparecimento de esporodóquios e conídios procedia-se à transferência para meio BDA ou V8 conforme descrito anteriormente. A incubação das culturas foi realizada em câmara biotronnette Mark III, contendo 3-4 lâmpadas fluorescentes de $40 \mathrm{w}$ a uma altura de $38 \mathrm{~cm}$, regulada para $25^{\circ} \mathrm{C} \pm 2^{0} \mathrm{C}$ e luz constante (Albuquerque, 1993). 


\subsection{2- Testes de patogenicidade}

\subsubsection{1- Produção do inóculo}

Nesta etapa do trabalho o inóculo nesessário para os testes de patogenicidade foi obtido mediante fragmentação das colônias sobre o meio V8 ( $100 \mathrm{ml}$ suco $\mathrm{V8}, 2,0 \mathrm{~g}$ de $\mathrm{CaCO}_{3}, 15 \mathrm{~g}$ de ágar e $900 \mathrm{ml}$ de água destilada). A incubação foi feita em câmara biotronette, conforme descrito anteriormente, por um período de 10 a 12 dias. No preparo do inóculo adicionaram-se cerca de $15 \mathrm{ml}$ de água destilada por placa, uma gota de espalhante (triton) e, por intermédio de um pincel de cerdas duras, procedia-se à liberação dos esporos por pincelamento das colônias. A suspensão obtida era filtrada e a concentração ajustada para $10^{4}$ a $10^{5}$ conídios $/ \mathrm{ml}$, em hemacitômetro de Newbauer.

\subsubsection{2- Avaliação da patogenicidade}

Os testes de patogenicidade foram realizados com 34 isolados oriundos de cinco Estados (SP, MG, BA, PE e AM), diferentes micro-regiões e 10 (dez) variedades (Nanicão; leite; Prata Anã; Grande Name; Prata; Nanica; Pacovan; Terra; Fhia-01 e Pioneira). Nas avaliações utilizaram-se três variedades de conhecida suscetibilidade à Sigatoka amarela(Prata Anã, Pacovan e Nanicão). As plantas foram obtidas de mudas convencionais, sendo cultivadas em sacos plásticos com uma mistura de terra, areia e esterco.

A inoculação foi feita por atomização, até início de escorrimento na face inferior das folhas 1 e 2 de cada planta, utilizando-se um atomizador plástico de $50 \mathrm{ml}$ de capacidade, reaproveitando-se um frasco spray de medicamento.

A incubação, pós-inoculação, foi feita de duas formas diferentes:

- Por ensacamento das folhas inoculadas, usando saco de polietileno transparente; 
- Por fechamento das plantas inoculadas em câmara plástica transparente; Em ambos os casos as plantas e/ou folhas inoculadas permaneciam em câmara úmida direta por $48 \mathrm{~h}$ em ambiente de telado, sendo posteriormente submetidas à alternância de ambiente por 45 dias, com 16-18h de alta umidade noturna seguido por período de 6-8h de baixa umidade diuma (Goos \& Tschirch, 1963). A alternância foi conseguida apenas com a colocação da câmara e/ou sacos plásticos diariamente por volta das 16:00h e sua retirada por volta das 9:00h da manhã. Os isolados patogênicos a pelo menos uma das variedades foram posteriormente cultivados em meio de BDA por 10 a12 dias e cobertos com óleo mineral, para preservação.

\subsection{3- Estudos de variabilidade}

\subsubsection{1- Produção do inóculo}

Os isolados obtidos, já preservados em óleo mineral, eram transferidos para meio de BDA e, após crescimento, repicados para meio V8 por fragmentação de colônias. Com cerca de sete dias, preparavam-se suspensões de esporos e micélio em água destilada estéril, a partir da cultura em V8, adicionando frações da mesma em tubos de ensaio com água estéril. Por agitação obtinha-se uma suspensão com cerca de $10^{5}$ U.F.C/ml(Unidades Formadoras de Colônias/ml). A partir dai seguiu-se a metodologia de Albuquerque (1993), na qual pipetava-se $0,2 \mathrm{ml}$ da suspensão transferindo para placa de petri com meio V8 e espalhava-se com alça de Drigalski. A incubação, porém, foi feita por apenas 8 dias nas mesmas condições já descritas e a concentração de inóculo utilizada foi de $4.10^{4}$ conídios/ml sem considerar, contudo, a presença de fragmentos de micélio na suspensão, que também são capazes de causar doença. 


\subsubsection{2- Inoculação}

Os isolados patogênicos selecionados após os testes descritos anteriormente foram inoculados em um grupo de cultivares de banana, tais como: Prata Anã; Pacovan; Terra; Nanicão; Mysore; Yangambi e pioneira, as quais compuseram o conjunto de diferenciadoras. Dos 34 isolados inicialmente avaliados, apenas dezoito foram submetidos ao estudo de variabilidade. Os mesmos foram divididos em três grupos, em função da proximidade das variedades sobre as quais foram obtidos e, cada grupo foi inoculado por vez, atomizando-se uma suspensão de esporos com $4.10^{4}$ conídios/ml na face inferior das folhas 1 e 2 de cada planta, para cada isolado.

Após a inoculação as plantas foram mantidas em telado sob irrigação por aspersão durante um período mínimo de $48 \mathrm{~h}$ e, posteriormente, seguiu-se a um regime de $3-4 \mathrm{~h}$ de aspersão diária, iniciando sempre ao final do dia (por volta das 16:00h) durante 55 dias. Isto permetia a manutenção da umidade ambiental próxima a $100 \%$ durante toda a noite, voltando a cair durante o dia, para níveis próximos aos $50 \%$, ocorrendo assim uma flutuação entre períodos de alta e baixa umidade, conforme recomendado por Goos \& Tschirch (1963).

\subsubsection{3- Parâmetros avaliados:}

\section{- Freqüência de lesões}

Para obtenção deste dado construiu-se um gabarito de $50 \mathrm{~cm}^{2}$, o qual foi colocado em quatro pontos distintos de cada folha inoculada, realizando-se 4 contagens por folha, conforme descrito:

Q1- quadrante da base, lado esquerdo do limbo foliar; 
Q2- quadrante apical, lado esquerdo do limbo foliar:

Q3- quadrante da base, lado direito do limbo foliar;

Q4- quadrante apical, lado direito do limbo foliar.

Na contagem das lesões consideraram-se aquelas alongadas a partir do estádio II, conforme definido por Brun (1963).

\section{- Severidade da doença}

A intensidade da doença nas folhas inoculadas foi avaliada mediante a utilização da escala descritiva proposta por Stover (1971), modificada por Gauhl (1994), como segue:

0 - Ausência de sintomas;

1 - Menos de 1\% da lâmina foliar com sintomas (presença de estrias e/ou superior a 10 manchas);

2 - De $1 \%$ a $5 \%$ da lâmina foliar com sintomas;

3 - De 6\% a $15 \%$ da lâmina foliar com sintomas;

4 - De $16 \%$ a $33 \%$ da lâmina foliar com sintomas;

5 - De $34 \%$ a $50 \%$ da lâmina foliar com sintomas;

6 - De $51 \%$ a $100 \%$ da lâmina foliar com sintomas;

- - Indica ausência de folha, folha morta ou caida junto ao pseudocaule.

\section{- Característica das lesões}

Três tipos de lesão foram classificadas, como segue:

N - Lesão normal ou de formato elíptico;

E - Lesão de formato estriado ou alongado;

O - Lesão ovalada ou arredondada.

$\mathrm{O}$ delineamento utilizado foi inteiramente aleatorizado em esquema fatorial $7 \times 18$ ( 7 genótipos $\times 18$ isolados) com oito repetições para o estudo de freqüência de lesões e 7 x 18 ( 7 isolados x 18 genótipos) com duas repetições, 
para severidade da doença. As análises estatísticas foram feitas pelo programa Sas (1994), versão 6.08, utilizando-se o teste t-Student para as comparações múltiplas de médias.

\section{3- RESULTADOS}

\subsection{1- Testes de patogenicidade}

A incubação pós-inoculação, realizada por ensacamento das folhas em sacos de polietileno transparente e por cobertura das plantas com câmaras plásticas transparentes apresentaram resultados semelhantes, propiciando um bom desenvolvimento da doença. São métodos perfeitamente recomendáveis para testes com plantas jovens e em pequeno número. As avaliações foram realizadas em três variedades comerciais e se limitaram a registrar os resultados como : ausência de sintomas $(-)$ e os níveis de severidade : $(+)$ baixa severidade; $(++)$ média severidade e $(+++)$ alta severidade. Dos trinta e quatro isolados avaliados apenas um não desenvolveu sintomas em nenhuma das variedades utilizadas, provavelmente devido à ausência de virulência sobre as mesmas, uma vez que o mesmo foi obtido sobre a variedade Leite, presente quase exclusivamente em bancos de germoplasma.

\subsection{2- Testes de variabilidade}

Dos dezoito isolados avaliados, coletaram-se dados de freqüência de lesões, conforme mostra a tabela 1 , e dados de severidade da doença, mostrados na tabela 2. Em ambos, a análise estatística revelou a presença de quinze isolados diferentes de $M$. musicola, em um grupo de apenas dezoito isolados avaliados. 
Uma análise de agrupamento dos isolados, realizada com a média dos dados transformados de freqüência de lesão e severidade foi realizada, sendo exemplificada na figura 1.

$\mathrm{Na}$ figura 2 estão ilustrados os tipos de Lesões, conforme definidos: Fig.2A, lesões normais sobre 'Prata Anã', causadas pelo isolado PA-Ti; Fig.2B, lesões estriadas sobre 'Pacovan', causadas por PA-Ti; Fig.2C, lesões ovaladas sobre 'Nanicão', causadas pelo isolado GN-Br e na Fig.2D, lesões estriadas sobre 'Pacovan', causadas por GN-Br. Nas interações isolado-cultivar avaliadas, registraram-se $63 \%$ de lesões normais, $35 \%$ de lesões estriadas e apenas $2 \%$ de lesões ovaladas.

Ainda na figura 2, pode-se observar as interações de incompatibilidade e/ou resistência, cujas lesões eram paralizadas nos estádios iniciais de desenvolvimento, conforme se pode observar na Fig.2E, F e G. A Fig.2E caracteriza uma reação tipo hipersensível, oriunda da interação da Yangambi com o isolado PC-La. Nas Fig. $2 F$ e 2G, caracterizam-se reações de alta resistência com as cultivares Pioneira e Terra, respectivamente. 
Tabela 1- Freqüência de lesões de Sigatoka $/ 50 \mathrm{~cm}^{2}$ de folha, observada aos 38 dias após a inoculação de um conjunto de variedades diferenciadoras com diversos isolados de Mycosphaerella musicola. Piracicaba, SP, 1997.

\begin{tabular}{|c|c|c|c|c|c|c|c|}
\hline & \multicolumn{7}{|c|}{ Variedades } \\
\hline Isolados & $\mathrm{PA}$ & PV & TR & MY & $\mathrm{NN}$ & $Y G$ & $\mathrm{PN}$ \\
\hline PA-Rg & $11.39 \mathrm{~A}$ & $5.75 \mathrm{AB}$ & $0.00 \mathrm{C}$ & $0.00 \mathrm{C}$ & $2.19 \mathrm{~B}$ & $0.00 \mathrm{C}$ & $0,00 \mathrm{C}$ \\
\hline $\mathrm{PA}-\mathrm{Nz}$ & $1.87 \mathrm{~A}$ & $0.26 \mathrm{~B}$ & $0.00 \mathrm{~B}$ & $0.08 \mathrm{~B}$ & $0.00 \mathrm{~B}$ & $0.00 \mathrm{~B}$ & $0,00 \mathrm{~B}$ \\
\hline PA-La & $68,94 \mathrm{~A}$ & $27,20 \mathrm{~A}$ & $0.00 \mathrm{~B}$ & $0.00 \mathrm{~B}$ & $18.40 \mathrm{~A}$ & $0,00 \mathrm{~B}$ & $0,00 \mathrm{~B}$ \\
\hline PA-Ti & $+3.94 \mathrm{~A}$ & $99.50 \mathrm{~A}$ & $0.00 \mathrm{~B}$ & $0.00 \mathrm{~B}$ & $34.10 \mathrm{~A}$ & $0,00 \mathrm{~B}$ & $0.00 \mathrm{~B}$ \\
\hline PA-Tu & $2.58 \mathrm{AB}$ & $1.06 \mathrm{~B}$ & $0.00 \mathrm{C}$ & $0.00 \mathrm{C}$ & $4.03 \mathrm{~A}$ & $0,00 \mathrm{C}$ & $0,00 \mathrm{C}$ \\
\hline PA-Ma & $10.61 \mathrm{~A}$ & $0.00 \mathrm{C}$ & $0.00 \mathrm{C}$ & $0.00 \mathrm{C}$ & $1.94 \mathrm{~B}$ & $0,00 \mathrm{C}$ & $0,00 \mathrm{C}$ \\
\hline $\mathrm{GN}-\mathrm{Br}$ & $50,52 \mathrm{~A}$ & $82,14 \mathrm{~A}$ & $0.00 \mathrm{~B}$ & $0,00 \mathrm{~B}$ & $30.36 \mathrm{~A}$ & $0.00 \mathrm{~B}$ & $0,00 \mathrm{~B}$ \\
\hline $\mathrm{GN}-\mathrm{Ca}$ & $8.68 \mathrm{~A}$ & $22.18 \mathrm{~A}$ & $0,00 \mathrm{C}$ & $0,00 \mathrm{C}$ & $0.76 \mathrm{~B}$ & $0,00 \mathrm{C}$ & $0,00 \mathrm{C}$ \\
\hline GN-Tu & $8,68 \mathrm{~B}$ & $68.94 \mathrm{~A}$ & $0.00 \mathrm{C}$ & $0,00 \mathrm{C}$ & $30.36 \mathrm{AB}$ & $0.00 \mathrm{C}$ & $0,00 \mathrm{C}$ \\
\hline $\mathrm{NC}-\mathrm{Ca}$ & $34,10 \mathrm{~A}$ & $27.20 \mathrm{~A}$ & $048 \mathrm{C}$ & $0.00 \mathrm{D}$ & $1,43 \mathrm{~B}$ & $0.00 \mathrm{D}$ & $0.00 \mathrm{D}$ \\
\hline NC-Ma & $155,75 \mathrm{~A}$ & $82.14 \mathrm{~A}$ & $1.02 \mathrm{~B}$ & $14,29 \mathrm{~A}$ & $50,52 \mathrm{~A}$ & $0.00 \mathrm{C}$ & $0,00 \mathrm{C}$ \\
\hline NC-Tu & $34.10 \mathrm{~A}$ & $3.66 \mathrm{~B}$ & $0.00 \mathrm{C}$ & $0.00 \mathrm{C}$ & $22.18 \mathrm{~A}$ & $0.00 \mathrm{C}$ & $0,00 \mathrm{C}$ \\
\hline PC-La & $3.20 \mathrm{~A}$ & $0.82 \mathrm{~B}$ & $0.00 \mathrm{C}$ & $0.00 \mathrm{C}$ & $0.92 \mathrm{~B}$ & $0.00 \mathrm{C}$ & $0.00 \mathrm{C}$ \\
\hline $\mathrm{PC}-\mathrm{Nz}$ & $5.75 \mathrm{~A}$ & $27.20 \mathrm{~A}$ & $0.00 \mathrm{C}$ & $0.00 \mathrm{C}$ & $0.27 \mathrm{~B}$ & $0.00 \mathrm{C}$ & $0.00 \mathrm{C}$ \\
\hline PC-Tu & $0,59 \mathrm{~B}$ & $7.66 \mathrm{~A}$ & $0.00 \mathrm{C}$ & $0,00 \mathrm{C}$ & $0,52 \mathrm{~B}$ & $0,00 \mathrm{C}$ & $0,00 \mathrm{C}$ \\
\hline $\mathrm{PV}-\mathrm{Ca}$ & $5.75 \mathrm{AB}$ & $34.10 \mathrm{~A}$ & $0.00 \mathrm{D}$ & $0.00 \mathrm{D}$ & $0.63 \mathrm{C}$ & $0.00 \mathrm{D}$ & $3,84 \mathrm{~B}$ \\
\hline PV-It & $9,27 \mathrm{~A}$ & $5.17 \mathrm{~A}$ & $0,00 \mathrm{D}$ & $2.37 \mathrm{C}$ & $0,30 \mathrm{~B}$ & $0.00 \mathrm{D}$ & $0,00 \mathrm{D}$ \\
\hline PV-Tu & $1.60 \mathrm{~B}$ & $5.45 \mathrm{~A}$ & $0.00 \mathrm{D}$ & $0,46 \mathrm{C}$ & $0.00 \mathrm{D}$ & $0.00 \mathrm{D}$ & $0,00 \mathrm{D}$ \\
\hline
\end{tabular}

$\mathrm{CV}=27,35 \%$. Dados transformados pela equação $\mathrm{Y}=(\mathrm{f}+0,5)^{-\sqrt{, 5}, 5}$, onde $f$ é a freqüência observada. Médias de variedades seguidas pela mesma letra na linha, não diferem estatisticamente, entre si, pelo teste de t-Student, ao n'vel 0,05 de probabilidade ; Variedades: PA=Prata Anã; PV=Pacovan; TR=Terra; MY=Mysore; NN=Nanicão; YG=Yangambi; $\mathrm{PN}=$ Pioneira; $\mathrm{GN}=$ Grande Naine; $\mathrm{NC}=$ Nanica; $\mathrm{PC}=$ Prata Comum. Locais: Rg=Registro-SP; $\mathrm{Nz}=$ Nazaré-BA; La=Lavras-MG; Ti=Tietê-SP; Tu=Turmalina-MG; $\quad \mathrm{Ma}=$ Manaus-AM; $\mathrm{Br}=$ Brotas-SP; $\mathrm{Ca}=$ Cruz das Almas-BA; It=Itambé-PE. 
Tabela 2- Severidade média do mal-de-Sigatoka observada aos 55 dias após a inoculação de um conjunto de variedades diferenciadoras com diversos isolados de Mycosphaerella musicola. Piracicaba, SP, 1997.

\begin{tabular}{|c|c|c|c|c|c|c|c|}
\hline \multicolumn{8}{|c|}{ Variedades } \\
\hline Isolados & PA & PV & TR & MY & $\mathrm{NN}$ & $\overline{Y G}$ & PN \\
\hline PA-Rg & $3.96 \mathrm{~A}$ & $2.03 \mathrm{~A}$ & $1.00 \mathrm{~B}$ & $0.01 \mathrm{C}$ & $4.17 \mathrm{~A}$ & $1.00 \mathrm{~B}$ & $1,00 \mathrm{~B}$ \\
\hline $\mathrm{PA}-\mathrm{Nz}$ & $1,77 \mathrm{~A}$ & $1.00 \mathrm{~A}$ & $0.01 \mathrm{~B}$ & $0.01 \mathrm{~B}$ & $1.00 \mathrm{~A}$ & $0.01 \mathrm{~B}$ & $0,01 \mathrm{~B}$ \\
\hline PA-La & $6.10 \mathrm{~A}$ & $+.88 \mathrm{~A}$ & $1.00 \mathrm{~B}$ & $1.00 \mathrm{~B}$ & $3.24 \mathrm{~A}$ & $1,00 \mathrm{~B}$ & $1,00 \mathrm{~B}$ \\
\hline PA-Ti & $5.76 \mathrm{~A}$ & $6.10 \mathrm{~A}$ & $1.00 \mathrm{~B}$ & $1.00 \mathrm{~B}$ & $+.39 \mathrm{~A}$ & $1.00 \mathrm{~B}$ & $1,00 \mathrm{~B}$ \\
\hline PA-Tu & $2.03 \mathrm{~A}$ & $2.33 \mathrm{AB}$ & $1.00 \mathrm{~B}$ & $1.00 \mathrm{~B}$ & $1.00 \mathrm{~B}$ & $1.00 \mathrm{~B}$ & $1.00 \mathrm{~B}$ \\
\hline PA-Ma & $2.55 \mathrm{~A}$ & $1.00 \mathrm{~B}$ & $0.01 \mathrm{C}$ & $1.00 \mathrm{~B}$ & $2.03 \mathrm{AB}$ & $1.00 \mathrm{~B}$ & $1.00 \mathrm{~B}$ \\
\hline $\mathrm{GN}-\mathrm{Br}$ & $5,76 \mathrm{~A}$ & $6.10 \mathrm{~A}$ & $1.00 \mathrm{~B}$ & $1,00 \mathrm{~B}$ & $6,10 \mathrm{~A}$ & $1.00 \mathrm{~B}$ & $1,00 \mathrm{~B}$ \\
\hline GN-Ca & $1.77 \mathrm{~A}$ & $2.03 \mathrm{~A}$ & $0.01 \mathrm{~B}$ & $1,00 \mathrm{~A}$ & $1.00 \mathrm{~A}$ & $1.00 \mathrm{~A}$ & $1,00 \mathrm{~A}$ \\
\hline GN-Tu & $1.77 \mathrm{AB}$ & $2.55 \mathrm{~A}$ & $0.32 \mathrm{C}$ & $1,00 \mathrm{~B}$ & $1.42 \mathrm{~B}$ & $1,00 \mathrm{~B}$ & $1,00 \mathrm{~B}$ \\
\hline $\mathrm{NC}-\mathrm{Ca}$ & $4.39 \mathrm{~A}$ & $5.16 \mathrm{~A}$ & $1.00 \mathrm{~B}$ & $1.42 \mathrm{~B}$ & $3.58 \mathrm{~A}$ & $1.00 \mathrm{~B}$ & $0,32 \mathrm{C}$ \\
\hline NC-Ma & $6,10 \mathrm{~A}$ & $6,10 \mathrm{~A}$ & $1,00 \mathrm{~B}$ & $4,39 \mathrm{~A}$ & $6.10 \mathrm{~A}$ & $1,42 \mathrm{~B}$ & $1,00 \mathrm{~B}$ \\
\hline NC-Tu & $2,33 \mathrm{AB}$ & $1.42 \mathrm{BC}$ & $0.01 \mathrm{D}$ & $1.77 \mathrm{ABC}$ & $3.40 \mathrm{~A}$ & $1.00 \mathrm{C}$ & $1,00 \mathrm{C}$ \\
\hline PC-La & $4,63 \mathrm{~A}$ & $1.42 \mathrm{~B}$ & $1.00 \mathrm{~B}$ & $1.42 \mathrm{~B}$ & $1,77 \mathrm{~B}$ & $1.00 \mathrm{~B}$ & $1,00 \mathrm{~B}$ \\
\hline $\mathrm{PC}-\mathrm{Nz}$ & $4.17 \mathrm{~A}$ & $+.88 \mathrm{~A}$ & $1.00 \mathrm{~B}$ & $1.42 \mathrm{~B}$ & $1.42 \mathrm{~B}$ & $1.00 \mathrm{~B}$ & $1.00 \mathrm{~B}$ \\
\hline PC-Tu & $2.80 \mathrm{AB}$ & $+.39 \mathrm{~A}$ & $1.00 \mathrm{C}$ & $1.42 \mathrm{BC}$ & $3.58 \mathrm{~A}$ & $1.00 \mathrm{C}$ & $1.00 \mathrm{C}$ \\
\hline PV-Ca & $3.96 \mathrm{AB}$ & $6.10 \mathrm{~A}$ & $1.00 \mathrm{C}$ & $1.00 \mathrm{C}$ & $2.02 \mathrm{BC}$ & $1.00 \mathrm{C}$ & $4,39 \mathrm{AB}$ \\
\hline PV-It & $4,63 \mathrm{AB}$ & $6,10 \mathrm{~A}$ & $1,00 \mathrm{C}$ & $4,88 \mathrm{~A}$ & $2.03 \mathrm{BC}$ & $1,00 \mathrm{C}$ & $1,00 \mathrm{C}$ \\
\hline PV-Tu & $2.55 \mathrm{~A}$ & $3.24 \mathrm{~A}$ & $1.00 \mathrm{~B}$ & $1.77 \mathrm{AB}$ & $1.00 \mathrm{~B}$ & $1.00 \mathrm{~B}$ & $1,00 \mathrm{~B}$ \\
\hline
\end{tabular}

$\mathrm{CV}=11,42 \%$

Dados transformados pela equação $Y=(s+0,5)^{-0,4}$, onde $s$ é a severidade observada.

Médias de variedades seguidas pela mesma letra na linha, não diferem estatisticamente, entre si, pelo teste de t-student, ao nível de 0,05 de probabilidade. Variedades: PA=Prata Anã; $\mathrm{PV}=$ Pacovan; $\quad \mathrm{TR}=$ =Terra; $\quad \mathrm{MY}=$ Mysore; $\quad \mathrm{NN}=$ Nanicão; $\quad \mathrm{YG}=$ Yangambi; $\quad \mathrm{PN}=$ =Pioneira; $\mathrm{GN}=$ Grande Naine; $\mathrm{NC}=$ Nanica e PC=Prata Comum. Locais: $\mathrm{Rg}=$ Registro-SP; $\mathrm{Nz}=$ Nazare-BA; $\mathrm{La}=$ Lavras-MG; Ti=Tietê-SP; Tu=Turmalina-MG; $\mathrm{Ma}=$ Manaus-AM; $\mathrm{Br}=\mathrm{Brotas}-\mathrm{SP} ; \mathrm{Ca}=\mathrm{Cruz}$ das Almas-BA e It=Itambé-PE. 


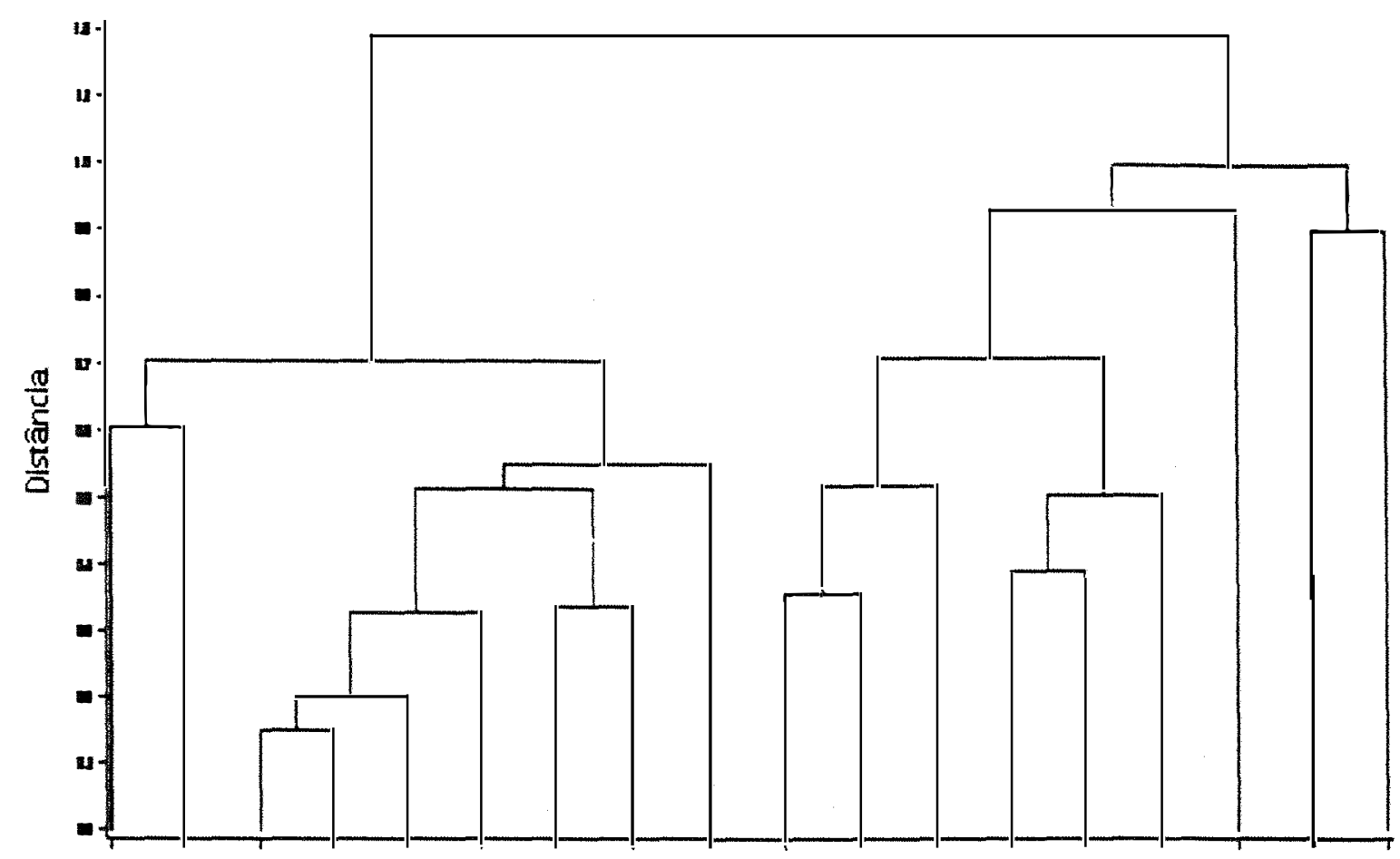

PA PC- GH- GH- PA PY PA HC- PA PA GH- PA HE- PE- PC- PY HE- PK

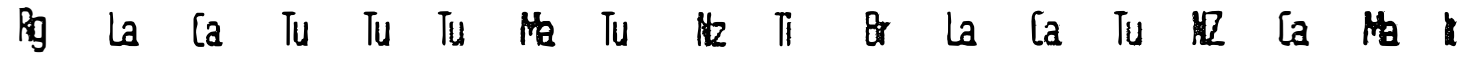
Isolados

Fig.1-Dendograma da análise de agrupamento de isolados de Pseudocercospora musae em função da severidade do mal-de-Sigatoka, sobre diferentes cultivares de bananeira. 

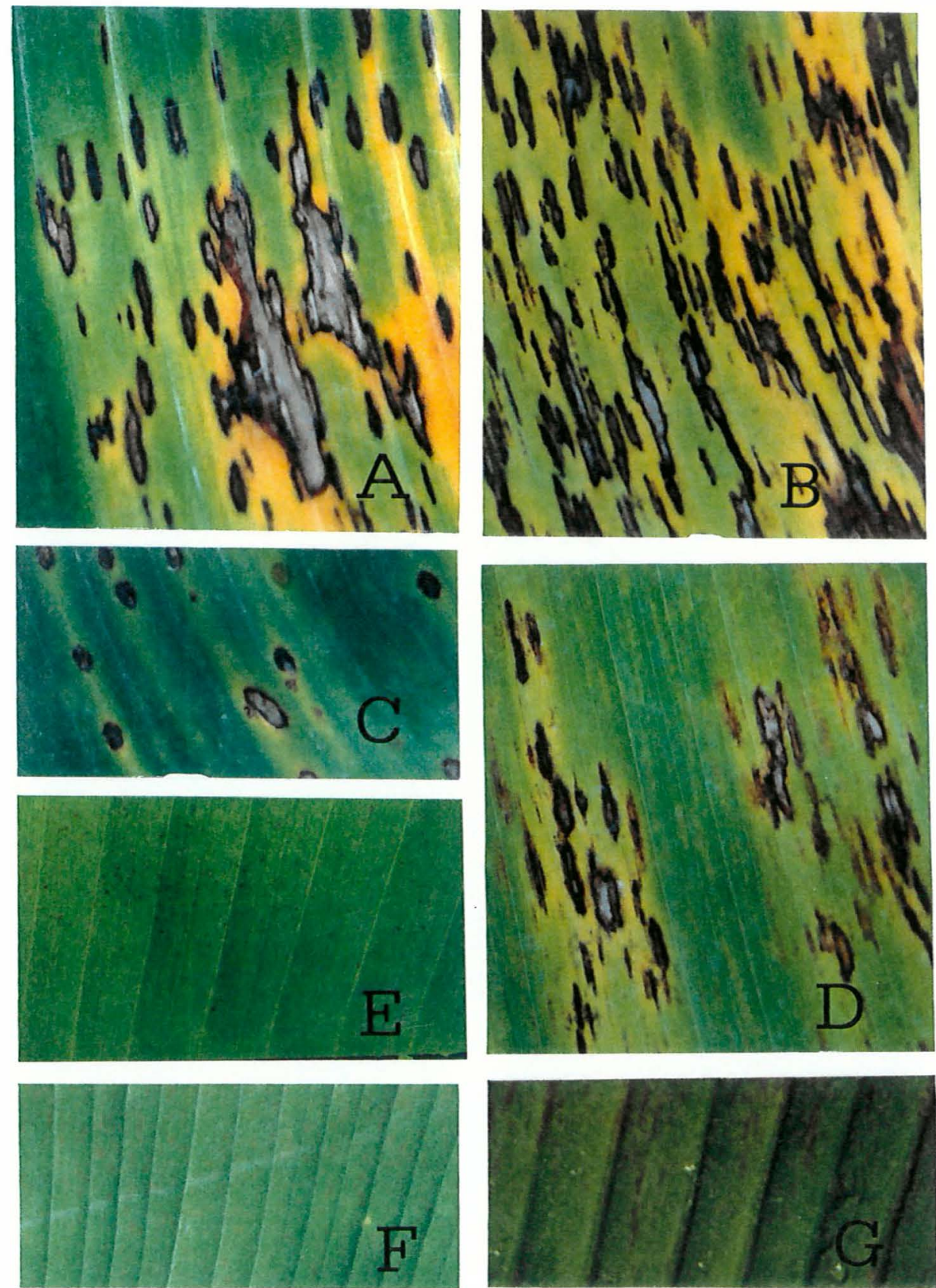

Fig.2 - Tipos de lesões suscetíveis e/ou reações de resistência observadas nas interações isolado-cultivar. A (normal) e B (estriada), causadas pelo isolado PA-Ti em Prata Anã e Pacovan. Em C (arredondada) e D (estriada), causadas pelo isolado $\mathrm{Gn}-\mathrm{Br}$ em Nanicão e Pacovan. Em E, F e $\mathrm{G}$ são reações de resistência, manifestadas por Yangambi, Pioneira e Terra, respectivamente. 


\section{4- DISCUSSÃO}

A presença de variabilidade patogènica entre isolados de $M$. musicola , obtidos a partir de variedades e regiões geográficas e climáticas diferentes, começou a ser visualizada durante a realização dos testes de patogenicidade, nos quais se utilizaram três variedades reconhecidas como suscetíveis ao mal-deSigatoka. Ocorreu porém, que alguns isolados quando inoculados sobre as três variedades já apresentavam, nesta fase, respostas diferentes, indicando claramente a presença de interação diferencial isolado-cultivar. Esses resultados mostram que 'Nanicão', 'Prata Anã' e 'Pacovan' não são, necessariamente, suscetíveis a todos os isolados ou raças presentes no ambiente.

A concretização da suspeita levantada durante os testes de patogenicidade, está claramente demonstrada tanto pelo parâmetro que considera freqüência de lesão por $50 \mathrm{~cm}^{2}$ de folha (tabela1), como pela análise da severidade da doença (tabela2) obtida pela escala de Gauhl (1994). Ambos apresentam interação isolado-cultivar, estatisticamente, altamente significativa. Os dois parâmetros considerados, identificam quinze isolados diferentes em uma amostra de dezoito, submetidos à inoculação sobre um conjunto de sete variedades diferenciadoras. $\mathrm{O}$ nível de variabilidade atinge um percentual de $83 \%$ dentro da amostra estudada. Considerando a importância da doença no cenário nacional e intermacional, o nivel de variabilidade é muito alto para ter passado desapercebido até os dias atuais. Apenas dois autores fazem menção a uma possível variação patogênica dentro da espécie Mycosphaerella musicola, baseados em observações de campo (Shepherd, 1990 ; Fouré \& Lescot, 1988). Além disto estudos de diversidade genética vêm sendo conduzidos, utilizando marcadores tipo RFLP

(Carlier et al. 1993 ; Carlier et al. 1994), sem contudo, considerar o estudo "in vivo". Nestes trabalhos observou-se que a maior diversidade estava entre os isolados do Sudeste Asiático, região de provável origem da espécie. Em outras zonas 
epidèmicas os mesmos formavam grupos geneticamente homogêneos, específicos de cada região (África, Ilhas do Pacífico, América Latina), apontando para uma limitada introdução de indivíduos em cada uma dessas regiões.

Em relação a isolados brasileiros não há estudos desta natureza que possam dar suporte à ampla variabilidade patogênica apresentada. Porém, a considerar pelo número de variedades cultivadas no Brasil, certamente maior do que na maioria das outras regiões produtoras do mundo; a diversidade climática em que a fruta é produzida de Norte a Sul do país; a presença da reprodução sexuada na espécie; a ocorrência de anastomose de hifas e sua capacidade de formar heterocárions, conforme demonstrado por Monnier (1986), são fatores que maximizam a capacidade de variação do patógeno e, consequentemente, a sua capacidade de adaptar-se a situações adversas. A variabilidade patogênica da espécie é fruto da variabilidade do hospedeiro, um fenômeno explicado pela coevolução, conforme enfatizado por Camargo (1995). Neste caso, a grande variabilidade apresentada pelos isolados avaliados, pode ser explicada exatamente pelo grande número de variedades cultivadas no Brasil. Além disto, segundo Camargo (1995), entre os mecanismos de variabilidade dos fungos, a reprodução sexuada destaca-se como o principal mecanismo amplificador da variabilidade, favorecendo a criação de novas raças com combinações inéditas de genes de virulência. O fato de M. musicola ser um fungo heterotálico (STOVER, 1963) é, certamente, um fator a mais no aumento da variabilidade.

A presença de virulência entre os isolados, em estudo, pode ser facilmente observada através da interação entre NC-Ma e PV-It sobre a variedade Mysore(MY), a qual foi resistente aos demais; entre o isolado PV-Ca e a variedade Pioneira, resistente aos demais isolados. Vale salientar ainda a variação em agressividade, observada principalmente dentro das cultivares, suscetíveis como a 'Prata Anã', 'Pacovan' e 'Nanicão'. A presença de interação diferencial 
foi demonstrada por Fullerton \& Olsen (1993), através de estudo in vivo, entre isolados de $M$. fijiensis e um conjunto de variedades diferencidoras.

A análise de agrupamento dos isolados, considerando a freqüência de lesões e a severidade, não define uma tendência de agrupamento dos mesmos, em função da variedade que deu origem ao isolado ou do local de coleta. Porém, se observa uma tendência em estabelecer subgrupos com características de virulência e/ou agressividade similares. Observando a Fig.1 percebe-se que os isolados GN-Ca e GN-Tu, formam um subgrupo bem próximo e, afastado deste, mas em distâncias equivalentes, está outro subgrupo formado pelos isolados PVCa, NC-Ma e PV-It, cada subgrupo com suas similaridades patogênicas.

Quanto à característica das lesčes (Fig.2), ou mais precisamente ao seu formato, aparentemente não é um fator dependente do isolado, mas sim da cultivar ou ainda do estádio fisiológico da folha. Sabe-se que inoculações realizadas em plantas jovens com folhas ainda tenras, dão origem a lesões de formato arredondado com bordos mal definidos (Mcgahan \& Fulton, 1965). Em geral, lesões arredondadas aparecem em menor número (Fig.2C), porém, são maiores e os danos, consequentemente, tornam-se equivalentes. Apenas para ilustrar as reações apresentadas pelas interações trabalhadas a nivel de genótipoisolado, pode-se observar na Fig.2E uma interação tipo hipersensível em Yangambi e, nas Figs.2F e $G$ são reações de alta resistência nos genótipos Pioneira e Terra, respectivamente.

\section{5- REFERÊNCIAS BIBLIOGRÁFICAS}

ALBUQUERQUE, P. S. B. Mycosphaerella musicola: produção de conídios in vitro; sensibilidade a fungicidas e avaliação da resistência em mudas de cultivares de bananeiras (Musa spp. ). Piracicaba, 1993. 94p. 
BRUN, J. La cercoporiose du bananier en Guinée. Étude de la phase ascosporée du Mycosphaerella musicola Leach, Paris, 1963, 196p. Thèse- Institut Français de Recherches Fruitières Outre Mer.

CAMARGO, L. E. A. Mecanismos de variabilidade genética de agentes fitopatogênicos. IN: BERGAMIM FILHO, A. ; KIMATI, H. \& AMORIM, L. Manual de Fitopatologia volume 1: princípios e conceitos, Ed. Agronômica Ceres, São Paulo, cap. 23, p.455-469, 1995.

CARLIER, J.; GONZALES DE LEON, D.; MOURICHON, X. \& ZAPATER, M. F. Genetic diversity of Mycosphaerella fijiensis, causal agent of black leaf streak in

banana. IN: GANRY, J. Breeding banana and plantain for resistance to diseases and pests. CIRAD-FLHOR, Montpellier, France, 1993, p 193-199.

CARLIER, J.; MOURICHON, X.; GONZALES DE LEON, D.; ZAPATER, M. F.\& LEBRUN, M. H. DNA Restriction Fragment lengt Polimorphisms in Mycosphaerella species that cause banana leaf spot diseases. Phytopathology, v.84, p.751-756, 1994.

FOURÉ, E. \& LESCOT, T. Variabilité des Mycosphaerella inféodés au genre Musa. Mise en évidence de la présence au Cameroun sur bananiers et plantains d'une cercosporiose (Mycosphaerella musicola) au comportement pathogène atypique. Fruits, v.43, p.407-415, 1988.

FULLERTON, R. A. \& OLSEN, T. L. Patogenic diversity in Mycosphaerella fijiensis Morelet. IN: GANRY, J.(Ed.) Breeding banana and platain for resistance to diseases and pests. Proceedings, Montpellier, France, CIRADFHLOR, 1993, P.201-211.

GAUHL, F. Epidemiology and ecology of black Sigatoka (Mycosphaerella fijiensis Morelet) on plantain and banana (Musa spp) in Costa Rica, Central America. Inibap, Montpellier, France, 1994.120p. 
GOOS, R. D. \& TSCHIRCH, M. Greenhouse studies on the Cercospora leaf spot of banana. Trans. Brit. Mycol. Soc. V.46, p.321- 330, 1963.

JONES, D. R.(ed.) The improvement and testing of Musa: a global partnership. Proceedings of the first global conference of the international Musa testing program held at FHIA, Honduras 27-30 april1994, Inibap, Montpellier, France, 1994. 303p.

MARTINEZ, J. A. O mal-de-Sigatoka e sua importância econômica para a bananicultura do Estado de São Paulo. O Biológico, v.66, p.271-280, 1970.

McGAHAN, M. W. \& FULTON, R. H. Leaf spot of banana caused by Mycosphaerella musicola: A comparative anatomical study of juvenile and adult leaves in relation to lesion morfology. Phytopathology, v.55, p.1179$1182,1965$.

MEREDITH, D. S. \& LAWRENCE, J. S. Black leaf streak disease of bananas (Mycosphaerella fijiensis): Suscetibility of cultivars. Trop. Agric., v.47, p.275-287, 1970.

MONNIER, E. Variabilité génétique des Mycosphaerella inféodés au genre Musa. Essai de mise en évidence d'échanges d'informations par fusion de cellules végétatives. Fruits, v.41, p.15-23, 1986.

MOURICHON, X. Mycosphaerella fijiensis: Diversity and possibilities for the early screening of germoplasm for resistance. IN: JONES, D. R. (ed.) The improvement and testing of Musa: a global partnership. Proceedings of the first global conference of the International Musa Testing Program held et FHIA, Honduras, 27-30 april 1994, Inibap, Montpellier, France, 1994. p.4753.

SAS USER'S GUIDE: STATISTIC, v.6 edition. SAS Institute Inc. 956p, 1994.

SHEPHERD, K. Genetic improvement of bananas in Brasil: aspects related to resistance to the genus Mycosphaerella. IN: FULLERTON, R. A. \& STOVER, R. H. (ed.) Sigatoka leaf spot of bananas. Proceedings of an 
international workshop held at San José, Costa Rica, 1989. Inibap, Montpellier, France, 1990. p. 243-251.

SIMMONDS, N. W. Bananas, $2^{\mathrm{a}}$ ed., London, Longman, 1966. 512p.

STOVER, R. H. Sexuality and heterothallism in Mycosphaerella musicola. Can. J. Bot. V. 41, p.1531-1532, 1963.

STOVER, R. H. A proposed international scale for estimating intensity of banana leaf spot (Mycosphaerella musicola). Trop. Agric., v.48, p. 185-196, 1971. STOVER, R. H. Banana, Plantain and Abaca disease, Commonwealth Mycological Institute, England, 1972, 316p. 


\section{CAPÍTULO II}

\section{4- INDUÇÃO DE RESISTÊNCIA À Mycosphaerella musicola EM BANANEIRA (Musa spp)}

\section{RESUMO}

O mal-de-Sigatoka, causado por Mycosphaerella musicola Leach, é a mais importante doença da bananeira no Brasil, contra a qual, o controle químico é a principal arma. A indução de resistência pode tornar-se uma importante alternativa de controle, haja vista, que variedades comerciais suscetíveis podem ser utilizadas mediante ativação de mecanismos de resistência presentes nas mesmas. O fenômeno é definido como a ativação de mecanismos de defesa, que estão latentes, mediante o tratamento com agentes bióticos e abióticos. Neste trabalho o objetivo foi testar a presença de resistência em plantas suscetíveis de 'Nanicão' e 'Prata Anã', ativadas por isolados incompatíveis de Mycosphaerella musicla ou por incubação pós-inoculação em ambiente desfavorável ao desenvolvimento da doença. As plantas ativadas foram submetidas à inoculação com dois isolados de M. musicola (PA-Ti e PA-Rg), comprovadamente virulento sobre as variedades, em dois experimentos distintos. Após a inoculação das plantas na face inferior das folhas 1 e 2 , elas foram mantidas em ambiente favorável ao desenvolvimento da doença, avaliando-se os parâmetros período de 
incubação, período de latência, período de desenvolvimento da doença, freqüência de lesões por $50 \mathrm{~cm}^{2}$ de folha e severidade. Os dados comprovaram a presença de resistência sistemicamente induzida, de magnitude elevada e alta persistência, uma vez que, a mesma motrou-se ativa quatro meses após a indução.

\title{
INDUCTION OF RESISTANCE AGAINST Mycosphaerella musicola IN BANANA (Musa spp)
}

\begin{abstract}
Chemical control is the major measure against Sigatoka disease caused by Mycosphaerella musicola Leach, the most important banana disease in Brazil. Induction of resistance, however, may become na important alternative, since susceptible commercial varieties can be employed for activation of latent defense mechanisms after treatment with biotic and abiotic agents. In this paper, activation of resistance in susceptible plants of Nanicão and Prata Anã was obtained by inoculation with incompatible isolates of M. musicola or by incubation, after inoculation, under unfavorable enviroment for the disease development. Two isolates of M.musicola (PA-Ti and PA-Rg) were inoculated in induced plants in two different trials. Both isolate had their pathogenicity previously confirmed against the varieties tested. Leaves 1 and 2 were inoculated by spraying a conidial suspension in the abaxial surface and maintained in a favourable environment for the disease. Incubation period, latent period, disease development period, number of lesions per $50 \mathrm{~cm}^{2}$ of leaf and severity were evaluated. The results showed the occurrence of systemically induced resistance which was highly persistent (effective up to 4 months after induction).
\end{abstract}




\section{1- INTRODUÇÃO}

O mal-de-Sigatoka, causado por Mycosphaerella musicola Leach (fase anamórfica Pseudocercospora musae (Zimm) Deighton) é a mais importante doença da bananeira no Brasil, sendo responsável por volumosas perdas na produção, haja vista que, para a produção de frutos de qualidade, torna-se indispensável a utilização do controle químico, até o momento, a principal arma do produtor (Martinez, 1970; Cordeiro \& Kimati, 1997). Diante deste quadro, a busca de alternativas menos onerosas e preservadoras do meio ambiente é fundamental na luta contra o avanço da doença.

Variedades resistentes são, sen dúvida, a opção ideal, porém, ainda não estão disponíveis como alternativa imediata. As variedades comerciais suscetíveis podem, no entanto, ser aproveitadas mediante a indução de resistência . O fenômeno é conhecido ainda como indução de proteção ou imunidade adquirida, sendo definido como a ativação de mecanismos de resistência, que estão latentes nas plantas suscetíveis, mediante ao tratamento das mesmas com agentes bióticos e abióticos. Entre os agentes bióticos podem ser utilizados microrganismos viáveis ou inativados e entre os abióticos destacam-se os metais pesados. Sabe-se que a proteção induzida é dependente de um intervalo de tempo entre o tratamento indutor e o desafiador, indicando assim a importância de alterações metabólicas na planta no sentido de síntese e/ou acúmulo de substâncias, as quais passarão a atuar local ou sistemicamente na proteção da planta, cujos mecanismos de resistência foram ativados (Pascholati \& Leite, 1995).

A literatura especializada destaca inúmeros exemplos da proteção induzida. Segundo Kuc \& Richmond (1977), a inoculação de cotilédones ou a primeira folha verdadeira de pepino com Colletotrichum lagenarium, protegia sistemicamente as plantas contra doenças causadas por subsequentes inoculações desafiadoras por este patógeno. Eles observaram ainda que havia uma relação 
direta entre o número de esporos utilizados na proteção (indução de resistência) e o aumento e duração da proteção. Observou-se também que uma proteção induzida por um periodo de seis semanas, progressivamente era reduzida durante este tempo e que a remoção da folha inoculada, para induzir a proteção, provocava uma progressiva redução da resistência, maior do que quando a mesma permancia ligada à planta (Dalisay \& Kuc, 1995). Resistência obtida pela inoculação prévia de raças não patogênicas a cultivares tem sido noticiada em fumo contra raças patogênicas de Phytophthora parasita var. nicotianae (Mc Intyre \& Miller, 1978); em feijão contra antracnose causada por raças de Colletotrichum lindemuthianum (Rahe et al., 1969); em milho evitando manchas foliares causados pela raça 1 de Helminthosporium carbonum, mediante prévia inoculação com a raça 2 (Cantone \& Dunkle, 1990); em cultivares de cevada contra míldio pulverulento causado por raças de Erysiphe graminis hordei (Ouchi et al., 1974). Relata-se também que a infecção de folhas inferiores de plantas de tomate por Phytophthora infestans, seguida por um período desfavorável ao desenvolvimento da doença aumenta a resistência geral das plantas contra 0 patógeno (Heller \& Gessler, 1986). A resistência induzida contra uma segunda infecção nas folhas superiores foi evidenciada pelo desenvolvimento de lesões necróticas bem definidas e de tamanho reduzido, além da supressão da esporulação do patógeno.

Não há nenhum relato, na literatura da ocorrência de resistência adquirida em bananeira. Porém, durante procedimentos de inoculação, envolvendo diferentes isolados de M.musicola, oriundos de regiões e de cultivares diferentes, com o objetivo de estudar a variabilidade patogênica dentro da espécie, observouse que nas plantas, sobre as quais, algum tipo de interação diferencial ocorria entre isolado-cultivar, estas passaram a exibir reações de resistência em inoculações posteriores, caracterizada principalmente por redução no número de lesões maduras e na velocidade de desenvolvimento das lesões. $\mathrm{O}$ mesmo foi 
observado quando uma planta de 'Nanicào' foi inoculada com isolado compatível, porém incubada em ambiente desfavorável ao desenvolvimento da doença. Com base nestas observações, experimentos foram conduzidos com o objetivo de se demonstrar o desenvolvimento de resistència sistêmica adquirida em variedades de banana contra o mal-de-Sigatoka, quando as mesmas foram submetidas à inoculação com isolados incompatíveis ou foram incubadas em ambiente desfavorável ao desenvolvimento da doença.

\section{2- MATERIAL E MÉTODOS}

O trabalho foi conduzido em doıs ensaios distintos, na área experimental do Departamento de Fitopatologia da ESALQ / USP, em Piracicaba, SP.

\subsection{1- Ensaio I}

Foi conduzido sob condições de telado, no qual testaram-se plantas ativadas para o desenvolvido de resistência induzida, conforme descrição apresentada na introdução.

Foram avaliadas quatro plantas das cultivares Nanicão e Prata Anã, previamente induzidas e duas plantas controle não induzidas.

Planta 1- Nanicão' submetido à incubação, pós-inoculação com isolado compatível, em ambiente desfavorável ao desenvolvimento do mal-de-Sigatoka (provavelmente devido à baixa luminosidade);

Planta 2- Nanicão' submetido à inoculação com isolado incompatível (PN-Nz); Planta 3- 'Prata Anã' manifestando resistência ao isolado GN-Br, onde esperavase suscetibilidade;

Planta 4- 'Prata Anã' manifestando resistência ao isolado NC-Tu, onde esperavase suscetibilidade; 
Planta 5- 'Nanicão', controle suscetível;

Planta 6- 'Prata Anã', controle suscetível.

O isolado PA-Ti de M. musicola, já testado sobre duas cultivares e tendo demonstrado virulência sobre as mesmas, foi utilizado neste ensaio. $O$ fungo foi crescido em meio V8 (100 ml de suco V8, $15 \mathrm{~g}$ de ágar, 2,0 g de $\mathrm{CaCO}_{3}$ e água destilada suficiente para completar $1000 \mathrm{ml}$ ) sob luz contínua e temperatura de $25^{\circ} \mathrm{C} \pm 2^{0} \mathrm{C}$. A repicagem do patógeno obedeceu ao sistema multi-ponto, mediante a adição, sobre o meio, de aproximadamente $0,2 \mathrm{ml}$ de suspensão, preparada em água estéril, contendo fragmentos do fungo, espalhando-se a seguir com alça de Drigalski. O preparo do inóculo foi feito após 8 dias de crescimento do fungo, ajustando-se a concentração, neste caso particular, para $8.10^{4}$ conídios/ml, que é o dobro da concentração normalmente utilizada nos testes de variabilidade. Vale ressaltar a presença de fragmentos de micélio na suspensão, sendo considerados apenas os conídios ao se fazer o ajuste em hemacitômetro.

A inoculação foi feita atomizando-se a suspensão na face inferior das folhas 1 e 2 das plantas, até o início de escorrimento superficial. Posteriormente, as bananeiras foram mantidas no telado com irrigação constante por $48 \mathrm{~h}$ e, após este período, uma alternância entre alta e baixa umidade foi conseguida mediante irrigação por 3-4 horas diárias, geralmente das 16 até às $20 \mathrm{~h}$.

\subsubsection{1- Parâmetros avaliados}

- Período de incubação(P.I.)- tempo em dias entre a data de inoculação e o aparecimento dos primeiros sintomas;

- Período de latência (P.L.)- intervalo de tempo entre a inoculação e o início da esporulação. Neste caso foi definido como o intervalo entre a inoculação e o 
aparecimento de lesões pretas, ocasião em que as lesões estão iniciando a esporulação;

- Período de desenvolvimento da doença (P.D.D)- intervalo de tempo entre a inoculação e o aparecimento do primeiro grupo de pelo menos 10 (dez) lesões maduras, ou seja, no estádio V conforme definido por Brun (1963).

- Freqüência de lesões (F.L.)- refere-se ao número de lesões por unidade de área, sendo avaliada aos 38 dias após a inoculação.

$\mathrm{Na}$ avaliação deste parâmetro foi preparado um gabarito de $50 \mathrm{~cm}^{2}$, o qual foi colocado em quatro pontos distintos de cada folha inoculada, sendo dois pontos na base do limbo e dois no ápice, assim definidos:

Q1- quadrante da base, lado esquerdo da folha;

Q2- quadrante apical, lado esquerdo da folha;

Q3- quadrante da base, lado direito da folha;

Q4- quadrante apical, lado direito da folha.

A opção pelo parâmetro freqüência de lesões se deve ao fato de que não há resistência à penetração e, portanto, avaliar freqüência de infecção não discrimina entre os genótipos. $\mathrm{Na}$ contagem das lesões consideraram-se apenas aquelas alongadas a partir do estádio II, definido por Brun (1963).

- Severidade da doença- refere-se à intensidade da doença nas folhas inoculadas aplicando-se a escala descritiva/diagramática, proposta por Stover (1971) e modificada por Gauhl (1994), como segue :

0 - Sem sintomas;

1- Menos de $1 \%$ da lâmina foliar com sintomas (presença de estrias e / ou superior a 10 manchas)

2- De 1 a 5\% da lâmina foliar com sintomas; 
3- De 6 a 15\% da lâmina foliar com sintomas;

4- De 16 a 33\% da lâmina foliar com sintomas:

5- De 34 a 50\% da lâmina foliar com sintomas:

6- De 5 I a 100\% da lâmina foliar com sintomas:

-- Indica ausência de folha, folha morta ou caida junto ao pseudocaule.

A severidade foi medida aos 42 dias após a inoculação, uma vez que, as folhas inoculadas nas plantas controle, já encontravam-se destruidas pela doença.

\subsection{2- Ensaio II}

Este ensaio foi conduzido três meses após o primeiro com algumas modificações, tais como:

1- A incubação das plantas inoculadas foi feita no interior de uma câmara plástica, para compensar as baixas temperaturas vigentes durante a realização do experimento (maio a julho). A câmara permanecia fechada das $16 \mathrm{~h}$ do dia anterior até as $10 \mathrm{~h}$ do dia seguinte, ou seja, $18 \mathrm{~h}$ fechada e $6 \mathrm{~h}$ aberta;

2- Mais uma planta de 'Nanicão'(NN/PA-Nz), com provável resistência induzida foi incluida no teste, uma vez que, a mesma apresentou interação incompatível com o isolado PA-Nz, obtido sobre a variedade Prata Anã;

3- O isolado utilizado neste experimento foi o PA-Rg, de comprovada virulência sobre as variedades Nanicão e Prata Anã, na mesma concentração de inóculo utilizada nos testes de resistência e variabilidade, ou seja, $4.10^{4}$ conídios $/ \mathrm{ml}$.

4- A tomada dos dados de freqüência de lesão foi efetuada aos 50 dias após a inoculação e os de severidade aos 70 dias, devido ao desenvolvimento mais lento da doença no período avaliado.

Todas as demais atividades deste experimento seguiram as mesmas orientações preconizadas no primeiro ensaio. As análises estatísticas foram feitas 
usando o programa Sas (1994), versào 6.08, utilizando-se o teste de T, para comparação das médias.

\section{3- RESULTADOS}

Os dados coletados sobre as variedades Nanicão e Prata Anã com provável resistência induzida incluem informações sobre período de incubação (P.I.), período de latência (P.L.), período de desenvolvimento da doença (P.D.D.) freqüência de lesões por $50 \mathrm{~cm}^{2}$ de folha (F.L.), severidade da doença (S.D.) e ainda uma estimativa do controle em relação à freqüência de lesões observada nos diferentes tratamentos, conforme mostra a Tabela 1. As plantas de 'Nanicão'l e 'Nanicão'2 foram desafiadas quatro meses após a indução. Já em relação às de 'Prata Anã' não se tem uma informação precisa, uma vez que, o indutor da resistência é desconhecido. Porém, o tempo entre a indução e o desafio, não é inferior a quatro meses. 
Tabela 1. Dados obtidos sobre plantas de banana com e sem indução de resistência contra o mal-de-Sigatoka, desafiadas com Mycosphaerella musicola (isolado PA-Ti). Piracicaba-SP, 1997.

\section{Parâmetros avaliados}

\begin{tabular}{lccccccc}
\cline { 4 - 7 } Plantas & Indutor & P.I. & P.L. & P.D.D. & S.D. & F.L. & \%Contr. \\
\hline Nanicão 1 & A.D. & $20,5 \mathrm{a}$ & $30,0 \mathrm{a}$ & $39,5 \mathrm{abcd}$ & $2,5 \mathrm{c}$ & $7,23 \mathrm{~b}$ & 85,2 \\
Nanicão 2 & PN-Nz & $22,5 \mathrm{a}$ & $42,5 \mathrm{a}$ & $45,0 \mathrm{abc}$ & $1,0 \mathrm{bc}$ & $1,31 \mathrm{~b}$ & 97,3 \\
Prata Anã 1 & I. D. & $21,0 \mathrm{a}$ & $39,5 \mathrm{a}$ & $45,0 \mathrm{ab}$ & $3,5 \mathrm{~b}$ & $5,74 \mathrm{~b}$ & 71,4 \\
Prata Anã 2 & I. D. & $22,5 \mathrm{a}$ & $42,5 \mathrm{a}$ & $52,0 \mathrm{a}$ & $2,5 \mathrm{bc}$ & $4,69 \mathrm{~b}$ & 50,3 \\
Nanicão 3 & controle & $19,0 \mathrm{a}$ & $26,5 \mathrm{a}$ & $31,0 \mathrm{bcd}$ & $6,0 \mathrm{a}$ & $93,43 \mathrm{a}$ & 0,0 \\
Prata Anã 3 & controle & $20,0 \mathrm{a}$ & $26,0 \mathrm{a}$ & $33,0 \mathrm{~d}$ & $6,0 \mathrm{a}$ & $48,53 \mathrm{a}$ & 0,0 \\
\hline CV \% & & 7,17 & 21,1 & 13,18 & 15,48 & 26,71 &
\end{tabular}

P.I.- Periodo de incubação em dias; P.L.- Período de latência em dias; P.D.D.- Período de desenvolvimento da doença em dias; S.D.- Severidade da doença; F.L.- Freqüência de lesões/ 50 $\mathrm{cm}^{2}$ de área foliar; \% contr.- Redução do número de lesões em relação à testemunha (dados não transformados); A.D. - Ambiente desfavorável; PN-Nz- Isolado que apresentou interação incompativel com Nanicão; I. D. - Isolado desconhecido de $M$. musicola indutor da resistência; * Dados transformados pela equaçào $Y=(f+0,5)^{-0.1}$; médias seguidas pela mesma letra na coluna não diferem estatisticamente, entre si, pelo teste t-Student ao nível 0,05 de probabilidade.

A Figura 1 mostra a presença da interação incompatível(A) entre a variedade Nanicão e o isolado $\mathrm{PN}-\mathrm{Nz}$ de $M$. musicola, isolado da variedade Pioneira, funcionando como indutor da resistência. Na mesma figura, observa-se o resultado obtido pela inoculação desafiadora na variedade Nanicão(B). Ao centro está a folha da planta controle não induzida e nas extremidades, duas folhas das plantas previamente induzidas, todas inoculadas com o isolado PA-Ti, obtido da variedade Prata Anã. Na Figura 2 observa-se a 'Prata Anã' com resistência induzida (A) e sem indução (B). As duas figuras mostram a 
magnitude do efeito da resistência induzida nas variedades Nanicão e Prata Anã, respectivamente.

Os dados da Tabela 2, referem-se a um segundo desafio, três meses após o primeiro, utilizando o isolado PA-Rg, que já havia demonstrado sua virulência sobre as variedades Nanicão e Prata Anã. Observe que a planta 'Nanicão'3 foi incluída. Trata-se de uma indução ocorrida através de um isolado de baixa agressividade e que não chegou a causar lesões maduras sobre 'Nanicão'. 

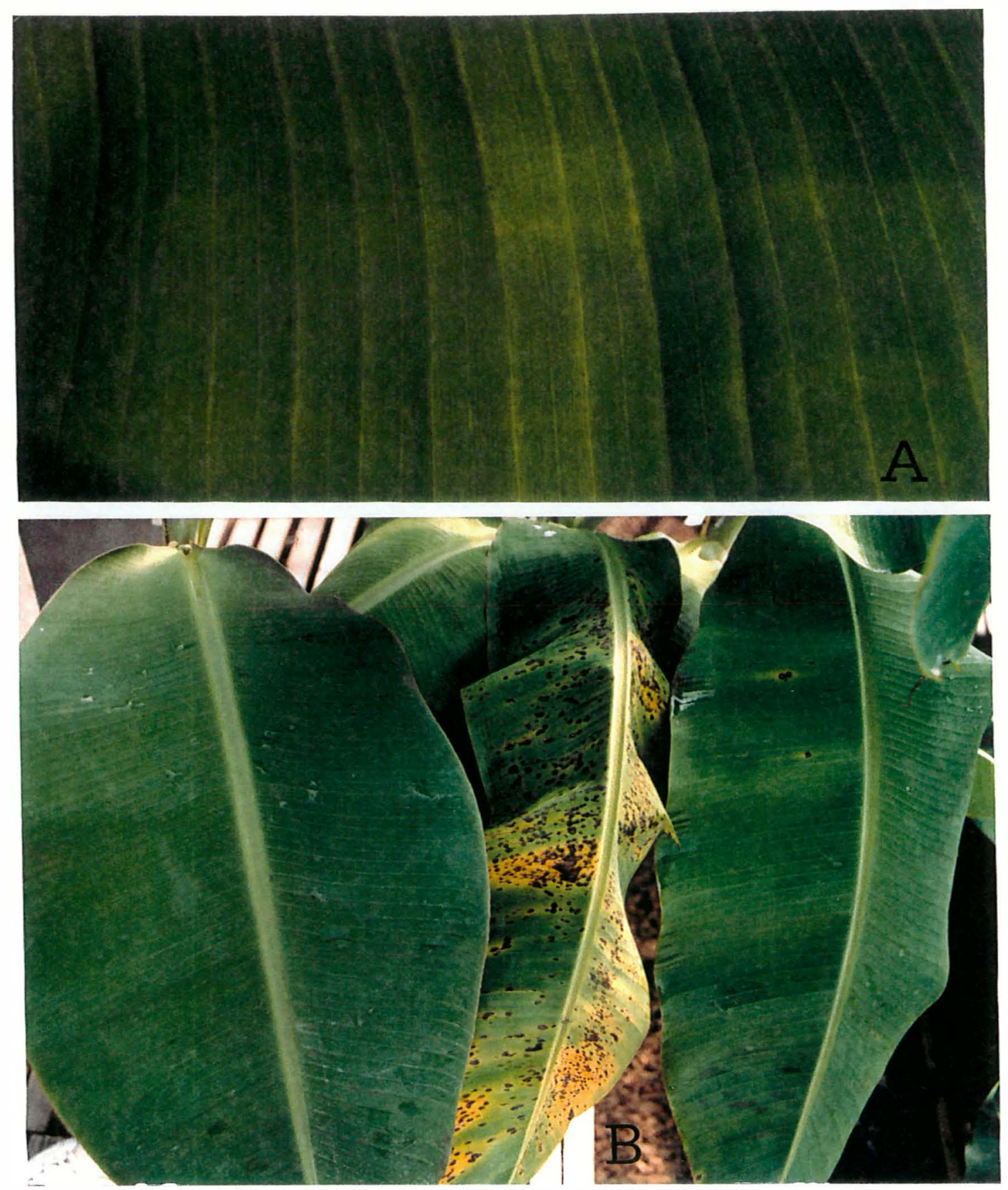

Fig. 1- Resultados das inoculações de indução(A) e de desafio(B) na variedade Nanicão. Em $\mathrm{B}$, observa-se o resultado da inoculação desafiadora com o isolado PA-Ti de Mycosphaerella musicola. Ao centro, sintomas do mal-de-Sigatoka na planta controle não induzida e nas extremidades, duas plantas previamente induzidas. $\grave{A}$ esquerda a indução ocorreu por incubação em ambiente desfavorável ao desenvolvimento da doença e à direita, por inoculação com isolado incompativel de Mycosphaerella musicola. 


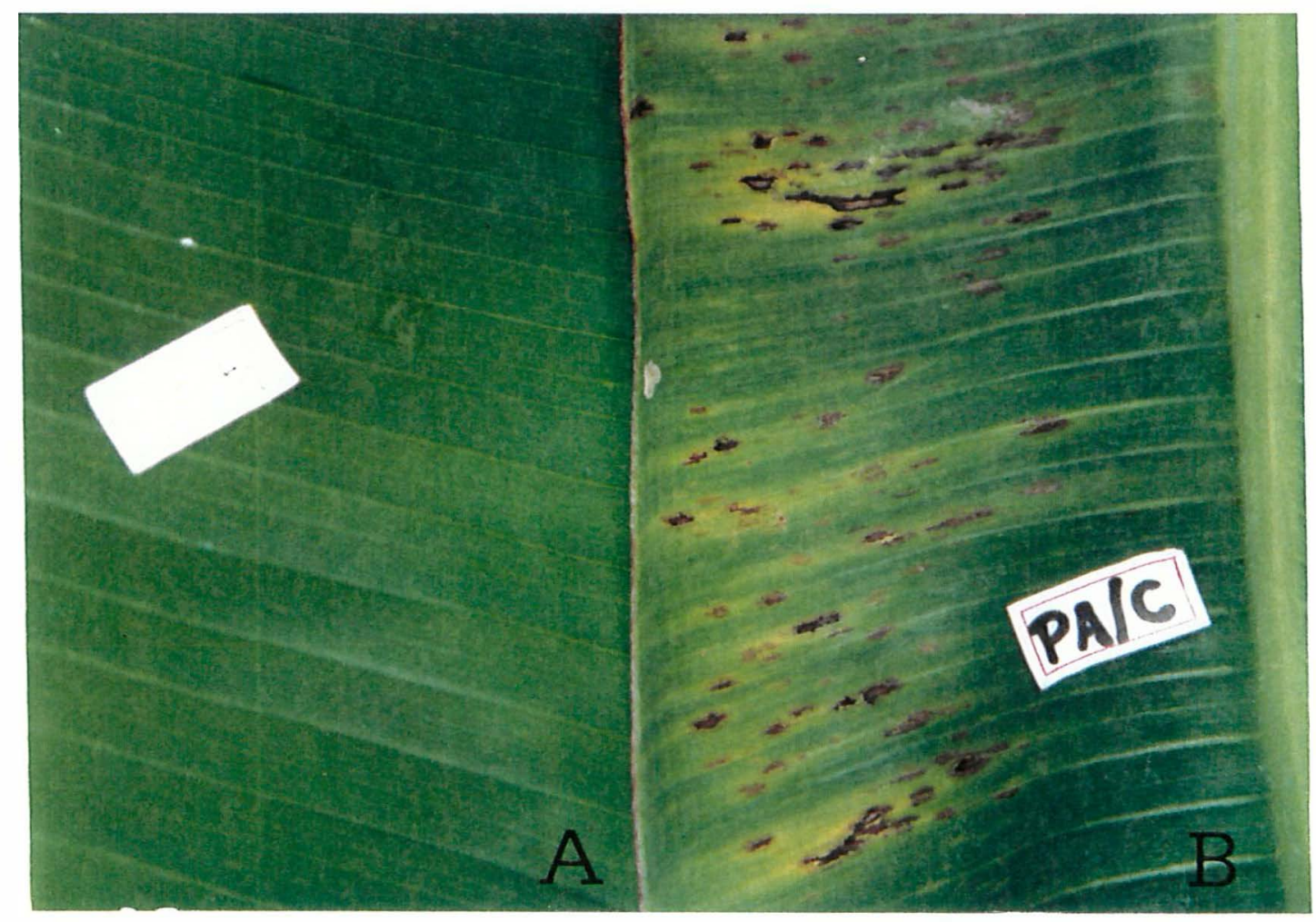

Fig. 2- Resultados da inoculação desafiadora em bananeira 'Prata Anã' inoculada com isolado virulento de Mycosphaerella musicola. Em A, observa-se uma folha da planta previamente induzida com isolado incompatível de $M$. musicola e, em B, folha controle de planta não induzida. 
Tabela 2- dados de um segundo desafio obtidos sobre plantas de bananeira com resistência induzida contra o mal-de-Sigatoka, desafiadas com Mycosphaerella musicola (isolado PA-Rg). Piracicaba-SP, 1997.

\begin{tabular}{lcccccc}
\hline & & \multicolumn{5}{c}{ paràmetros avaliados } \\
\cline { 3 - 7 } Plantas & A.I. & P.L. & P.D.D. & S.D. & F.L. & \% Contr. \\
\hline Nanicão 1 & A.D. & $59,50 \mathrm{a}$ & $70,50 \mathrm{a}$ & $3,00 \mathrm{~b}$ & $0,00 \mathrm{c}$ & 100 \\
Nanicão 2 & PN-Nz & $58,00 \mathrm{ab}$ & $66,00 \mathrm{a}$ & $3,5 \mathrm{ab}$ & $0,20 \mathrm{c}$ & 93,42 \\
Prata Anã 1 & I. D. & $49,00 \mathrm{c}$ & $54,00 \mathrm{~b}$ & $5,00 \mathrm{ab}$ & $16,27 \mathrm{a}$ & 0,00 \\
Prata Anã 2 & I. D. & $48,50 \mathrm{c}$ & $52,00 \mathrm{~b}$ & $5,00 \mathrm{ab}$ & $21,48 \mathrm{a}$ & 25,07 \\
Nanicão 3 & PA-Nz & $56,00 \mathrm{ab}$ & $65,00 \mathrm{a}$ & $3,00 \mathrm{~b}$ & $0,92 \mathrm{bc}$ & 78,38 \\
Nanicão 4 & controle & $48,00 \mathrm{c}$ & $52,00 \mathrm{~b}$ & $5,5 \mathrm{a}$ & $3,47 \mathrm{ab}$ & 0,00 \\
Prata Anã 3 & controle & $53,50 \mathrm{~b}$ & $63,00 \mathrm{a}$ & $4,5 \mathrm{ab}$ & $7,79 \mathrm{a}$ & 0,00 \\
\hline CV \% & & 3,72 & 2,21 & 24,56 & 31,66 & \\
\hline
\end{tabular}

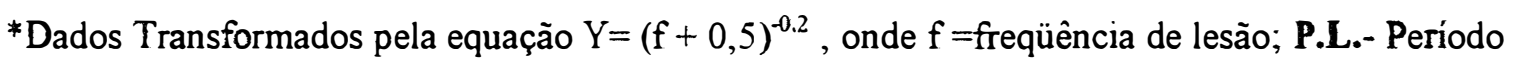
de latência; P.D.D.- Periodo de desenvolvimento da doença; S.D.- Severidade da doença; F.L.Freqüência de lesões; \% contr. - Redução de lesões em relação ao controle(dados originas); A.I.Agente indutor; A.D.- Ambiente desfavorável; $\mathrm{PN}-\mathrm{Nz}$ e $\mathrm{PA}-\mathrm{Nz}$ - Isolados de reação incompativel sobre 'Nanicão'; I. D. - Isolado desconhecido de Mycosphaerella musicola indutor de resistência sobre 'Prata Anä'.

\section{4- DISCUSSÃO}

Entre os parâmetros avaliados (Tabela 1), o período de incubação não apresentou diferença estatística significativa, o que também já era esperado, uma vez que, nas avaliações de resistência, principalmente a Sigatoka negra, este parâmetro não tem apresentado correlação com resistência (Fouré, 1985). Em relação ao período de latência (P.L.), também não se observa diferença estatística e, embora o período de desenvolvimento da doença (P.D.D.), tenha mostrado 
alguma diferença estatística, ao contrário do que se imagina, não foram importantes na avaliação da resistência, provavelmente porque na avaliação destes parâmetros leva-se em conta apenas o aparecimento de um pequeno grupo de lesões (cerca de dez lesões), sem se preocupar com maiores quantidades. Vê-se que o coeficiente de variação foi relativamente elevado, e talvez por isso, não tenham aparecido as diferenças estatísticas esperadas. O P.D.D. é considerado por Fouré (1985) um importante parâmetro na avaliação da resistência à Sigatoka negra, a nível de campo. Neste trabalho, porém, os parâmetro severidade da doença (S.D.) e freqüência de lesão (F.L.), foram os que melhor traduziram a resistência exibida pelas plantas avaliadas. As quatro plantas suspeitas de apresentarem resistência induzida tiveram comportamento bastante similar, com diferenças estatísticas altamente significativas em relação ao controle. Pela coluna percentagem de controle pode-se ordenar os melhores níveis de resistência: Nanicão 2, Nanicão 1; Prata Anã 1 e Prata Anã 2.

Os resultados comprovam o desenvolvimento de uma resistência sistemicamente induzida, uma vez que a mesma se manifestou à distância do local de indução, apresentando magnitude elevada, visto que, as plantas, principalmente de Nanicão, paralisaram quase por completo o desenvolvimento da doença (Fig. 1) e ainda, de alta persistência, haja vista que, o desafio foi feito quatro meses após a indução e mesmo assim a resposta foi positiva. Os dados da literatura tem se referido a até seis semanas em pepino (Dalisay \& Kuc, 1995), embora não seja uma boa comparação para bananeira.

É interessante observar que a resistência pode ser induzida por uma interação incompatível isolado-cultivar, caracterizada pela não virulência do isolado sobre o cultivar (Fig. 1a) como no caso do genótipo NN/PN-Nz, sendo já bastante exemplificado na literatura (Mcintyre \& Miller, 1978; Rahe et al. 1969 Cantone \& Dunkle, 1990; Ouchi et al. 1974), ou ainda, por uma interação incompativel facultada pelo ambiente, ou seja, o isolado utilizado era compatível, 
mas o ambiente desfavorável tornou a interação incompatível. Um caso semelhante foi registrado em tomate por Heller \& Gessler (1986), onde infecções por Phytophthora infestans, seguido por um período desfavorável conferiam proteção contra infecções posteriores, traduzidas por redução no tamanho das lesões, lesões bem definidas e supressão da esporulação.

Os dados da Tabela 2 complementam os da tabela 1, visto que, mostram o que se pode esperar na indução de resistência. A partir de um determinado tempo após a indução, o nível de proteção começa a diminuir. Isto pode ser observado na Tabela 2. Embora ainda se mantenham algumas diferenças estatísticas, principalmente nas plantas de Nanicão em relação ao controle, há uma queda considerável no nível de proteção. Pelo parâmetro severidade, apenas 'Nanicão' 1 e 'Nanicão'3 diferiram da testemunha. Observa-se, contudo, que houve um atraso significativo no desenvolvimento das lesões, considerando os parâmetros período de latência e período de desenvolvimento da doença. Conforme já enfatizado, este último, é considerado por Fouré (1985), como um excelente parâmetro na medição da resistência da bananeira ao mal-de-Sigatoka. Nas plantas 'Prata Anã' 1 e 2 o comportamento foi semelhante ao controle, sinal de que o efeito indutor havia cessado. Isto indica que a resistência uma vez induzida, se manterá operante por um período ao redor de quatro meses, fato que torna a descoberta ainda mais importante. Os resultados obtidos, neste experimento, abrem novas e enormes perspectivas de trabalho na busca de alternativas menos onerosas e preservadoras do meio ambiente, para o controle do mal-de-Sigatoka. É importante que outros trabalhos sejam realizados no sentido de definir novas formas ou agentes de indução, a persistência do efeito indutor, a caracterização bioquímica da indução e a aplicação prática da técnica. 


\section{5- REFERÊNCIAS BIBLIOGRÁFICAS}

ALBUQUERQUE, P. S. B. Mycosphaerella musicola: produção de conídios in vitro; sensibilidade a fungicidas e avaliação de resistência em mudas de cultivares de bananeira (Musa spp). Piracicaba, sp, 1993. 94p. Tese (M.S.) Escola Superior de Agricultura Luiz de Queiróz"-Universidade de São Paulo.

BRUN, J. La cercoporiose du bananier en Guinée. Étude de la phase ascosporée du Mycosphaerella musicola Leach, Paris, 1963, 196p. Thèse- Institut Français de Recherches Fruitières Outre Mer.

CANTONE, F. A. \& DUNKLE, L. D. Resistance in susceptible maize to Helminthosporium carbonum race 1 induced by prior inoculation with race 2 . Phytopathology, v.80, n.11, p. 1221-1224, 1990.

CORDEIRO, Z. J. M. \& KIMATI, H. Doenças da Bananeira (Musa spp) IN: KIMATI, H. ; AMORIM, L. ; BERGAMIM FILHO, A. ; CAMARGO, L. E. A. \& REZENDE, J. A. M. Manual de Fitopatologia, volume 2: Doenças das plantas cultivadas, Ed. Agronômica Ceres, São Paulo, cap. 13, p. $112-$ 136, 1997.

DALISAY, R. F. \& KUC, J. A. Persistence of induced resistance and enhanced peroxidase and chitinase activities in cucumber plants. Physiol. Molec. Plant Pathol., v.47, p. 315 - 327, 1995.

FOURÉ, E. Les cercosporioses du bananier et leurs traitements. Comportement des variétés. Etude de la sensibilité variétale des bananiers et plantains à Mycosphaerella fijiensis Morelet au Gabon (maladie des raies noires). (suite III). Fruits, v.40, p.393-399, 1985. 
FUCHS, J. G. ; MOËNNE-LOCCOZ, Y. \& DÉFAGO, G. Nonpathogenic Fusarium oxysporum strain Fo47 induces resistance to Fusarium wilt in tomato. Plant Disease, v.81, p. $492-496,1997$.

GAUHL, F. Epidemiology and ecology of black Sigatoka (Mycosphaerella fijiensis Morelet) on plantain and banana (Musa spp) in Costa Rica, Central America. Inibap, Montpellier, France, 1994.120p.

HELLER, W. E. \& GESSLER, C. Induced sistemic resistance in tomato plants against Phytophthora infestans. J. Phytopathol., v.116, p.323-328, 1986.

HWANG, B. K.\& HEITEFUSS, R. Induced resistance of spring barley to Erysiphe graminis f. sp hordei. Phytopath. Z., v.103, p. 4 1-47, 1982.

JONES, D. R.(ed.) The improvment and testing of Musa: a global partmership. Proceedings of the first global conference of the international Musa testing program held at FHIA, Honduras 27-30 april1994, Inibap, France, 1994.303p KESSMANN, H. ; STAUB, T. ; LIGON, J. ; OOSTENDORP, M. \& RYALS, J. Activation of sistemic acquired disease resistance in plants. European Journal of Plant Pathology, v. 100, p.359 - 369, 1994.

KUC, J. \& RICHMOND, S. Aspects of protection of cucumber against Colletotrichum lagenarium by Colletotrichum lagenarium. Phytopathology, v.67, p.533 - 536, 1977.

MARTINEZ, J. A. O mal-de-Sigatoka e sua importância econômica para a bananicultura do Estado de São Paulo. O Biológico, v.66, p.271-280, 1970

Mc INTYRE, J. L. \& MILLER, P. M. Protection of tobacco against Phytophthora parasitica var. nicotianae by cultivar-nonpathogenic races, cell-free sonicates, and Pratylenchus penetrans. Phytopathology, v.68, p.235-239, 1978.

OUCHI, S. ; OKU, H. ; HIBINO, C. \& AKIYAMA, I. Infection of accessibility and resistance in leaves of barley by some races of Erysiphe graminis. Phythopath. Z., v.79, p.24-34, 1974. 
PASCHOLATI, S. F. \& LEITE, B. Hospedeiro: Mecanismos de resistência. IN: BERGAMIM FILHO, A.; KIMATI, H. \& AMORIM, L. Manual de Fitopatologia, volume 1: princípios e conceitos, Ed. Agronômica Ceres, São Paulo, cap. 22, p.417-453, 1995.

RAHE, J. E. ; KUC, J. ; CHUANG. C. M. \& WILlIAMS, E. B. Induced resistance in Phaseolus vulgaris to bean anthracnose. Phytopathology, v. 59, p.1641- 1645, 1969.

SAS USER'S GUIDE: STATISTICS, v. 6 edition. SAS Institute Inc. 956p, 1994.

STOVER, R. H. A proposed international scale for estimating intensity of banana leaf spot (Mycosphaerella musicolc:). Trop. Agric., v.48, p.185-196, 1971. STOVER, R. H. Banana, plantain and abaca disease, Commonwealth Mycological Institute, England, 1972. 316p. 


\section{CAPÍTULO III}

\section{5- RESISTÊNCIA DE GENÓTIPOS DE BANANEIRA AO \\ MAL-DE-SIGATOKA}

\section{RESUMO}

A busca de resistência como altemativa para o controle do mal-deSigatoka da bananeira, causado por Mycosphaerella musicola (=Pseudocercospora musae), é uma prioridade para o programa brasileiro de pesquisa com banana, dada a importância da doença. Neste trabalho, o objetivo foi avaliar a resistência de genótipos de bananeira a nível de campo, sob infecção natural, e em telado, mediante inoculação artificial. Em condições de campo foram avaliados os genótipos 'Prata Anã', 'Pacovan', 'Nanicão', 'Mysore', 'Yangambi', 'Pioneira', 'JV03-15', 'PV03-44', 'FHIA-01' e 'FHIA-18'. Nas avaliações em telado, foi incluido a este grupo de genótipos a variedade 'Terra'. Os mesmos foram testados mediante inoculação com seis isolados, variantes em virulência e/ou agressividade, atomizando uma suspensão com $4.10^{4}$ conídios $/ \mathrm{ml}$ na face inferior das folhas 1 e 2 . Os resultados obtidos em telado, revelaram uma resistência caracterizada pela presença de interação diferencial altamente siginificativa entre isolado-cultivar, que a classifica como tipicamente vertical. As interações observadas apresentaram reações fenotipicas, também observadas em 
campo, tipo hipersensibilidade, alta resistência, resistência intermediária e suscetibilidade. Os resultados sugerem que, diante da variabilidade do patógeno, as avaliações de campo tornam-se desaconselháveis.

\title{
RESISTANCE OF BANANA GENOTYPES AGAINST SIGATOKA DISEASE
}

\begin{abstract}
The search for resistance as an alternative for the control of the Sigatoka disease of banana, caused by Mycosphaerella musicola (=Pseudocercospora musae), is a priority of the brazilian banana research program, due to the importance of the disease. The objective of this study was to evaluate the resistance of banana genotypes under natural infection in the field or by artificial inoculation with the pathogen under a shade screen protection. In the field, 'Prata Anã', 'Pacovan', 'Nanicão', 'Mysore', 'Yangambi', 'Pioneira', 'JV03-15', 'PV03-44', 'FHIA-01' and 'FHIA-18' were the genotypes evaluated. The variety 'Terra' was added to these genotyps in the evaluation performed through artificial inoculation. Six isolates of the pathogen were inculated by atomization of a suspension of $4.10^{4}$ conidia/ml on the lower surface of the leaves 1 and 2 . The results of the inoculation test showed a significative differential interaction between isolates and banana genotypes, indicating the existence of vertical resistance in this pathosystem. Different phenotypic reactions were observed, such as hipersensibility, high resistance, intermediate resistance and suscetibility, being similar under natural infection and artifitial inoculation. The results suggest that due to the variability of the pathogen, field evaluations are not recomended.
\end{abstract}




\section{1- INTRODUÇÃO}

A bananeira é plantada de Norte a Sul do Brasil e, em maior ou menor intensidade, ela é afetada pelo mal-de-Sigatoka, também conhecido entre nós como Sigatoka amarela ou cercosporiose. É causada pelo fungo Mycosphaerella musicola Leach (forma perfeita) ou Pseudocercospora musae (Zimm) Deighton (forma anamórfica), o qual é responsável pelo desfolhamento da planta provacado pela morte prematura das folhas. Como conseqüência há um depauperamento geral da planta, refletindo em menor número de frutos por cacho e menor tamanho de fruto além da ocorrência de maturação precoce no campo. Há estimativa de que esta perda atinja 50\% da produção (Martinez, 1970) mas, dependendo do microclima, ela poderá chegar aos 100\%. Até o momento a principal arma dos produtores, para o controle da doença, tem sido os defensivos químicos. Porém, pela própria característica da bananicultura brasileira, onde predominam os pequenos produtores, em geral descapitalizados e com conhecimentos técnicos abaixo do necessário para administrar a utilização continuada dos defensivos químicos, esta pode não ser a melhor alternativa para enfrentar o problema. A busca de variedades resistentes é uma prioridade mundial, na qual o Brasil está inserido com significativa participação. Esta é, sem dúvida, uma alternativa tecnológica da maior importância porque, além de atingir a todos os estratos de produtores, é uma tecnologia preservadora do meio ambiente.

São vários os programas de melhoramento de banana em andamento hoje na mundo, que englobam em seus objetivos a obtenção de variedades resistentes à Sigatoka amarela e/ou Sigatoka negra. O programa brasileiro, iniciado em 1982, tem gerado híbridos tetraplóides com resistência a Sigatoka amarela (Soares Filho et al., 1990 ; Shepherd et al., 1992). A seleção destes genótipos, entretanto, tem sido feita com base apenas na quantidade de doença visualmente observada, sob 
condições naturais de infecção a campo. É importante, porém, que avaliações mais acuradas sejam realizadas, para que, gradativamente, as informação acumuladas permitam um melhor conhecimento da natureza da resistência presente nesses genótipos.

$\mathrm{Na}$ avaliação da resistência da bananeira à Sigatoka amarela, Simmonds (1966) reconheceu quatro classes de reação: altamente suscetivel; ligeiramente suscetível; resistente e altamente resistente. Posteriormente, Vakili (1968) avaliou espécies de Musa acuminatta e variedades comestíveis em relação à M. musicola, medindo o período de incubação, período entre a fase de estrias e lesões maduras, número de manchas por planta, número da folha mais jovem com lesões maduras e número de esporodóquios por lesào. $\mathrm{O}$ mesmo concluiu que era possível classificar os genótipos em altamente resistentes, resistentes, parcialmente resistentes, suscetíveis e altamente suscetíveis. Shillingford (1974) avaliou as variedades Valery e Robusta, ambas AAA, medindo os parâmetros, porcentagem de manchamento de folhas, folha mais jovem manchada e número de folhas verdes. Observou que cultivares de constituição genômica semelhante, como neste caso, podem apresentar diferenças na quantidade de doença, dependendo da taxa de emergência de folhas. Segundo o autor, parece haver dois componentes na resistência à Sigatoka. O maior deles é geneticamente controlado e afeta a latência da doença, enquanto o menor é um tipo de resistência de campo baseada numa maior velocidade de produção de folhas, possibilitando, assim, a permanência de uma maior área foliar verde na planta.

O patossistema Sigatoka amarela-bananeira foi trabalhado na Austrália por Jones (1995), com utilização de uma técnica rápida para avaliar resistência de germoplasma de bananeira, em condições controladas, usando fragmentos de micélio como inóculo. Após a inoculação as plantas eram mantidas em nevoeiro por sete dias e, posteriormente, por um período de 23 a 34 dias, em fotoperíodo de $16 \mathrm{~h}$ de dia e $8 \mathrm{~h}$ de noite. Os resultados definiram genótipos suscetíveis (grande 
número de lesões), de resistência parcial (algumas lesões jovens) e extremamente resistentes (ausência de sintomas).

A maioria dos trabalhos atuais estão voltados para Sigatoka Negra causada por M. fijiensis. Meredith \& Lawrence (1970) mediram: taxa de emergência de folhas; número da folha mais velha com os primeiros sintomas; número da folha mais velha com manchas; freqüência de formação de manchas; intensidade de estrias; área da estria; número de folhas funcionais na época da colheita e abundância de formação de conídios. Concluíram que todas as cultivares testadas foram suscetíveis à infecção, mas com graus de variação, definindo-se três níveis de resposta com base em um sistema de escore arbitrário: altamente suscetível, moderadamente suscetível e ligeiramente suscetível. Observa-se que tanto com Sigatoka amarela como com Sigatoka negra, as discussões apenas se limitam a classificar os genótipos avaliados em um determinado grupo fenotípico como altamente resistente, resistente, suscetível, etc, sem apresentar comentários sobre a resistência observada. Parâmetros como formação de conidióforos e conídios, formação de peritécios e ascósporos, período de incubação, período de evolução da lesão, folha mais jovem necrosada, folha mais jovem infectada e rítmo de emissão de folhas têm sido considerados (Fouré, 1982 ; Fouré et al, 1984 ; Fouré, 1985). Segundo Fouré (1993), quatro fenótipos distintos podem ser observados entre os genótipos avaliados: Alta Resistência, Resistência Parcial, Suscetível e Altamente Suscetível. Entre os parâmetros utilizados na avaliação, Fouré (1985) observa que não há correlação entre período de incubação e resistência à Sigatoka negra, mas que o período de evolução das lesões, embora seja influenciado pelas condições climáticas, juntamente com o número de folhas funcionais na época da colheita traduzem perfeitamente o grau de sensibilidade de uma cultivar.

Neste trabalho, o objetivo foi avaliar a resistência de genótipos de bananeira, a nível de campo com infecção natural e em telado, mediante inoculação artificial, visando estabelecer correlações entre os resultados. 


\section{2- MATERIAL E MÉTODOS}

Conforme previsto no objetivo, o trabalho foi conduzido com um experimento de campo, instalado no município de Tietê-SP, e outro em telado conduzido na área experimental do Departamento de Fitopatologia da ESALQ/USP.

\subsection{1- Avaliação da resistência de genótipos de bananeira sob condições de telado}

O experimento foi conduzido em condições de telado rústico, no Departamento de Fitopatologia da ESALQ/USP. Foram testados onze genótipos pertencentes a três grupos genômicos diferentes: AAA ('Nanicão' e 'Yangambi'); AAB ('Prata Anã', 'Pacovan', 'Mysore' e 'Terra'), AAAB ('Pioneira', 'JV0315', 'PV03-44', 'FHIA-01' e 'FHIA-18') contra seis isolados que se mostraram diferentes, frente a um grupo de sete variedades diferenciadoras (capítulo I). As plantas utilizadas foram produzidas em sacos plásticos contendo uma mistura de terra, areia e esterco, produzidas a partir de gemas obtidas de frações do rizoma. À época da inoculação apresentavam mais de quatro folhas e altura superior a $1 \mathrm{~m}$. A inoculação foi feita na página inferior das folhas 1 e 2 de cada planta (Mourichon, et al.1987 ; Jones, 1995), pulverizando-se uma suspensão contendo 4. $10^{4}$ conídios $/ \mathrm{ml}$. O inóculo foi obtido em meio $\mathrm{V} 8$, sob luz constante e temperatura de $25 \pm 2^{\circ}$, C (Albuquerque, 1993). A incubação das plantas inoculadas foi feita em telado aplicando-se um esquema flutuante de umidade (Goos \& Tschirch, 1963), mediante irrigação por aspersão sob copa. Logo após a inoculação, irrigava-se por $48 \mathrm{~h}$ seguidas e, posteriormente, 3-4h diárias de irrigação aplicadas a partir das 16h, para garantir a flutuação da umidade. 


\subsubsection{1- Dados coletados}

-Período de incubação(P.I.)- tempo em dias entre a data da inoculação e o aparecimento dos primeiros sintomas.

-Período latente(P.L.)- intervalo de tempo entre a inoculação e o início da esporulação. Neste caso, foi definido como intervalo entre a inoculação e o desenvolvimento de lesões pretas, ocasião em que as lesões estão iniciando a esporulação.

-Período de desenvolvimento da doença (P.D.D.)- intervalo de tempo entre a inoculação e o aparecimento do primeiro grupo de pelo menos 10 (dez) lesões maduras, ou seja, no estádio V conforme definido por Brun (1963).

-Freqüência de lesões (F.L.)- refere-se ao número de lesões por unidade de área, sendo avaliadas aos 38 dias após a inoculação.

$\mathrm{Na}$ avaliação deste parâmetro foi preparado um gabarito de $50 \mathrm{~cm}^{2}$, o qual foi colocado em quatro pontos distintos de cada folha inoculada, sendo dois pontos na base do limbo e dois no ápice, assim definidos:

Q1- quadrante da base, lado esquerdo da folha;

Q2- quadrante apical, lado esquerdo da folha;

Q3- quadrante da base, lado direito da folha;

Q4- quadrante apical, lado direito da folha.

A opção pelo parâmetro freqüência de lesões se deve ao fato de que não há resistência à penetração e, portanto, avaliar freqüência de infecção não discrimina entre os genótipos. Na contagem das lesões consideraram-se apenas aquelas alongadas a partir do estádio II, definido por Brun (1963). 
- Severidade da doença- refere-se à intensidade da doença nas folhas inoculadas aplicando-se a escala descritiva, proposta por Stover (1971) e modificada por Gauhl (1994), como segue :

0 - sem sintomas;

1- menos de $1 \%$ da lâmina foliar com sintomas (presença de estrias e/ou superior a 10 manchas);

2- De 1 a $5 \%$ da lâmina foliar com sintomas;

3- De 6 a 15\% da lâmina foliar com sintomas;

4- De 16 a 33\% da lâmina foliar com sintomas;

5- De 34 a 50\% da lâmina foliar com sintomas;

6- De 51 a 100\% da lâmina foliar com sintomas;

-- Indica ausência de folha, folha morta ou caída junto ao pseudocaule.

As análises estatísticas foram realizadas pelo programa Sas (1994), versão 6.08, utilizando-se o teste de t- Student e/ou Tukey para as comparações múltiplas das médias.

\subsection{2- Avaliação da resistência de genótipos de bananeira sob condições naturais de infeç̧ão}

O ensaio foi conduzido em área de produtor, localizada no município de Tietê-SP, a $30 \mathrm{~km}$ de Piracicaba. No local são cultivados 20 ha de banana das variedades Nanicão e Prata Anã, ambas altamente suscetíveis à Sigatoka amarela, cuja incidência, requer a utilização do controle químico durante o período chuvoso. O objetivo do experimento foi medir sob condições de inóculo natural, alguns parâmetros que pudessem caracterizar a resistência dos dez genótipos avaliados, os quais incluíram:

-Triplóides AAB: Pacovan, Prata Anã e Mysore;

-Triplóides AAA: Nanicão e Yangambi; 
-Tetraplóides AAAB: Pioneira, FHIA-01, FHIA-18, JV03-15 e PV03-44.

As mudas destes genótipos foram produzidas em sacos plásticos contendo uma mistura de terra areia e esterco, plantadas com gemas obtidas a partir de frações do rizoma. As mesmas foram transferidas para campo em novembro de 1996, ocasião em que já apresentavam quatro folhas. Cerca de dois meses após o plantio deu-se início à coleta de dados, que estendeu-se de janeiro de 1997 a maio do mesmo ano.

O delineamento experimental utilizado foi o inteiramente ao acaso, com dez tratamentos (cada genótipo constituiu um tratamento) e nove repetições. As plantas foram dispostas em espaçamento $2,5 \mathrm{~m} \times 2,0 \mathrm{~m}$, onde cada planta constituia uma parcela. O experimento foi implantado no meio do bananal, estando circundado por plantas de 'Nanicão' e 'Prata Anã', bastante atacadas pelo mal-de-Sigatoka.

\subsubsection{1- Dados coletados}

- Período de incubação (PI)- Corresponde ao período decorrido entre a infecção e o aparecimento dos primeiros sintomas, que neste caso, correspondeu-se ao período decorrido entre a data de marcação da folha no estádio $B$ e o aparecimento dos primeiros sintomas, corresponde a estrias amarelas nas plantas suscetíveis (Jones, 1994).

- Período latente ( PL )- Corresponde ao período decorrido entre a infecção até que $50 \%$ das lesões estejam esporulando. Neste caso específico o PL foi definido como o período decorrido entre a inoculação e o aparecimento de lesões pretas, ocasião em que as mesmas começam a esporular. 
- Período de desenvolvimento da doença (PDD)- Compreende ao período decorrido entre a inoculação e o aparecimento de lesões maduras, que corresponde ao estádio $\mathrm{V}$, conforme definido por Brun (1963). O PDD foi anotado quando a folha apresentou 10 ou mais lesões maduras ou necróticas.

- Folha mais jovem infectada ( FMJI ) - Corresponde à folha mais jovem da planta a apresentar o primeiro grupo de 10 lesões no estádio I (estrias amarelas). A anotação foi feita quando se comprovava o período de incubação, anotando-se o número da folha mais jovem infectada.

- Folha mais jovem manchada ( FMJM ) - Corresponde à folha mais jovem da planta a apresentar o primeiro grupo de 10 lesões nos estádios IV e V, ou seja, lesões maduras. A anotação da FMJM ocorreu por ocasião da marcação do PDD nas folhas marcadas.

- Severidade da doença (S.D.) - Corresponde à percentagem de tecido doente tomado em todas as folhas da planta, aplicando-se a escala descritiva proposta por Stover (1971) e modificada por Gauhl (1994). Os dados foram tomados a cada vinte dias, a partir de 27/01/97 até 12/05/97. Estes dados foram posteriormente transformados em índice de infecção (I.D.), de acordo com a fórmula proposta para a avaliação internacional de Sigatoka negra (Jones, 1994), como segue:

$$
\text { Índice de Doença. }=\frac{\sum \mathrm{nb}}{(\mathrm{N}-1) \mathrm{T}} \times 100
$$

Onde:

$\mathrm{n}=$ número de folhas em cada escore;

$\mathrm{b}=$ escore;

$\mathrm{N}=$ número de graus usados na escala (7); 
$\mathrm{T}=$ número total de folhas avaliadas.

\section{3- RESULTADOS}

\subsection{1- Dados obtidos em condições de telado}

Os dados obtidos neste ensaio referem-se à freqüência de lesões do malde-Sigatoka por $50 \mathrm{~cm}^{2}$ de folha (Tabela 1), severidade da doença obtida no final do experimento (Tabela 2) e periodo de incubação (Tabela 3). Na Figura 3 estão representados graficamente os dados de período de incubação (P.I.), período de latência (P.L.) e período de desenvolvimento da doença (P.D.D.). Informações sobre os principais tipos de interações observadas entre os isolados avaliados e os diversos genótipos de bananeira estão registrados na Figura 4.

\subsection{2- Dados obtidos em condições de campo}

No campo foram coletadas informações sobre período de latência (P.L.), período de desenvolvimento da doença (P.D.D.), folha mais jovem infectada (F.M.J.I.) e folha mais jovem manchada (F.M.J.M.), as quais estão representadas graficamente na Figura 3. Na Figura 4 estão os dados de período de incubação (P.I.) e índice de doença (I.D.), obtido a partir dos dados de severidade. 
Tabela 1- Freqüência média de lesões de Sigatoka por $50 \mathrm{~cm}^{2}$ de folha obtida aos 38 dias após a inoculação de seis isolados de Mycosphaerella musicola sobre onze genótipos de bananeira, mantidas em condição de telado. Piracicaba, SP, 1997.

\begin{tabular}{|c|c|c|c|c|c|c|}
\hline \multirow[b]{2}{*}{ Genótipos } & \multicolumn{6}{|c|}{ Isolados } \\
\hline & PA-Rg & PA-Ti & $\mathrm{NC}-\mathrm{Ca}$ & NC-Ma & $\mathrm{PV}-\mathrm{Ca}$ & PV-It \\
\hline PA & $12,36 \mathbf{b} \mathbf{A}$ & 48,05 ab A & 38,75 ab A & 125,71 a $\mathbf{A}$ & $8,81 \mathbf{b} \mathbf{A B}$ & 16,12 b A \\
\hline PV & 5,89 b AB & $97,16 \mathbf{a ~ A}$ & 28,48 ab A & 76,02 a A & 38,75 a A & $14,74 \mathbf{a b} \mathbf{A B}$ \\
\hline TR & $0,00 \mathbf{b} \mathbf{E}$ & $0,00 \mathbf{b} \mathbf{E}$ & 0,66 a C & 1,75 a C & 0,00 b D & 0,00 b C \\
\hline MY & $0,00 \mathbf{c ~ E}$ & $0,00 \mathbf{c ~ E}$ & $0,00 \mathbf{c ~ D}$ & $19,37 \mathbf{a} \mathbf{A B}$ & 0.00 c D & 3,44 b B \\
\hline $\mathrm{NN}$ & 3.19 c ABC & 34.90 b AB & 2,55 с BC & 60.14 a A & 1.19 cd C & $0,45 \mathbf{d ~ C}$ \\
\hline YG & $0,00 \mathbf{a} \mathbf{E}$ & 0,00 a E & 0,00 a D & 0,00 a D & 0,00 a D & 0,00 a C \\
\hline PN & $0,32 \mathbf{b} \mathbf{D E}$ & $0,00 \mathbf{b} \mathbf{E}$ & 0,00 b D & 0,00 b D & 8,12 a $\mathbf{A B}$ & 0,00 b C \\
\hline $\mathrm{JV}$ & $1,19 \mathbf{a b} \mathbf{C D}$ & 4,67 a CD & 0,73 bc $\mathbf{C}$ & $0,00 \mathbf{d} \mathbf{D}$ & $0,00 \mathbf{d} \mathbf{D}$ & 0,18 cd C \\
\hline PV03 & 1,39 bc CD & $1,51 \mathbf{b c} \mathbf{D}$ & 3,19 b B & 48,05 a A & 1,39 bc c & 0,36 c C \\
\hline F01 & $0,00 \mathbf{c ~ E}$ & 4,67 a CD & 2,04 ab BC & 4,67 a BC & 0,00 c D & $0,61 \mathbf{b c} \mathbf{C}$ \\
\hline F18 & 1.51 с BCD & 8,81 ab BC & 2,20 bc BC & 23.41 a A & 3.19 bc BC & $0,00 \mathbf{d ~ C}$ \\
\hline
\end{tabular}

$\mathrm{CV}=21 \%$

Médias seguidas pela mesma letra minúscula, na linha, não diferem estatisticamente, entre si, pelo teste de t- Student a $5 \%$ de probabilidade e/ou pela mesma letra maiúscula na coluna. PAPrata Anã; PV-Pacovan; TR-Terra; MY-Mysore; NN-Nanicão; YG-Yangambi; PN-Pioneira; JVJV03-15; PV03-PV03-44; F01-FHIA-01; F18-FHIA-18; NC-Nanica; Rg-Registro-SP; Ti-TietêSP; Ca-Cruz das Almas-BA; Ma-Manaus-AM; It-Itambé-PE. 
Tabela 2- Severidade média do mal-de-Sigatoka, obtida aos 55 dias após a inoculação de seis isolados de Mycosphaerella musicola, sobre onze genótipos de bananeira, para a avaliação da resistència em condições de telado. Piracicaba, SP, 1997.

\begin{tabular}{|c|c|c|c|c|c|c|}
\hline \multirow[b]{2}{*}{ Genótipos } & \multicolumn{6}{|c|}{ Isolados } \\
\hline & PA-Rg & PA-Ti & $\mathrm{NC}-\mathrm{Ca}$ & $\mathrm{NC}-\mathrm{Ma}$ & $\mathrm{PV}-\mathrm{Ca}$ & PV-It \\
\hline PA & 3,87 a A & $5,53 \mathbf{a ~ A}$ & 4,29 a A & $5,96 \mathbf{a ~ A}$ & $3,87 \mathbf{a} \mathbf{A B}$ & 4,51 a A \\
\hline PV & $2,01 \mathbf{b} \mathbf{A B}$ & $5,96 \mathbf{a ~ A}$ & 5,00 a A & 5,96 a A & $5,96 \mathbf{a ~ A}$ & 5,96 a A \\
\hline TR & 1,01 a BC & $1,01 \mathbf{a} \mathbf{B}$ & 1,01 a DE & $1,01 \mathbf{a ~ B}$ & 1,01 a D & 1,01 a B \\
\hline MY & $0,00 \mathbf{c ~ D}$ & 1.01 b B & 1,45 b CD & 4.29 a A & 1.01 b D & 4,87 a A \\
\hline $\mathrm{NN}$ & $3,97 \mathbf{a b c} \mathbf{A}$ & 4,29 ab A & 3,48 abc $\mathbf{A B}$ & $5,96 \mathbf{a} \mathbf{A}$ & 2,07 bc BCD & $2,01 \mathbf{c ~ B}$ \\
\hline YG & $1,01 \mathbf{a} \mathbf{B C}$ & 1,01 a B & 1,01 a DE & 1,45 a B & 1,01 a D & 1,01 a B \\
\hline PN & 1,01 b BC & $1,01 \mathbf{b ~ B}$ & $0,37 \mathbf{b} \mathbf{E}$ & 1,01 b B & $4,29 \mathbf{a} \mathbf{A B}$ & $1,01 \mathbf{b ~ B}$ \\
\hline $\mathrm{JV}$ & 1,01 a $\mathbf{B C}$ & 1,79 a B & 1,45 a CD & 1,45 a B & 1,01 a $\mathbf{D}$ & 1,01 a B \\
\hline PV3 & 1,45 b B & 1,01 b B & $3,87 \mathbf{a} \mathbf{A B}$ & 3,57 a A & 1,45 b CD & 1,45 b B \\
\hline F01 & $0,37 \mathbf{c ~ C D}$ & 1.45 ab B & 2,45 a BC & 1,45 ab B & 1,01 bc $\mathbf{D}$ & $1,41 \mathbf{a b ~ B}$ \\
\hline F18 & $1,01 \mathbf{c ~ B C}$ & 2,01 bc B & $2,97 \mathbf{a b} \mathbf{A B C}$ & 429 a A & $2,38 \mathbf{a b ~ B C}$ & $1,01 \mathbf{c ~ B}$ \\
\hline
\end{tabular}

$\mathrm{CV}=35 \%$

Médias seguidas pela mesma letra minúscula, na linha, e/ou, pela mesma letra maiúscula na coluna, não diferem estatisticamente, entre si, pelo teste de $t$ - Student, a $5 \%$ de probabilidade. Variedades: PA-Prata Anã; PV-Pacovan; TR-Terra; MY-Mysore; NN-Nanicão; YG-Yangambi; PN-Pioneira; JV-JV03-15; PV3-PV03-44; F01-FHIA-01; F18-FHIA-18; NC-Nanica; Locais: Rg-Registro-SP; Ti-Tietê-SP; Ca-Cruz das Almas-BA; Ma-Manaus-AM; It-Itambé-PE. 
Tabela 3- Período de incubação médio observado sobre diversos genótipos de bananeira inoculados com seis isolados de Mycosphaerella musocola, sob condições de telado. Piracicaba, 1997.

\begin{tabular}{|c|c|c|c|c|c|c|}
\hline \multirow[b]{2}{*}{ Genótipos } & \multicolumn{6}{|c|}{ Isolados } \\
\hline & PA-Rg & PA-Ti & $\mathrm{NC}-\mathrm{Ca}$ & NC-Ma & $\mathrm{PV}-\mathrm{Ca}$ & PV-It \\
\hline $\mathrm{PA}$ & 22,0 a B & 21,0 ab CD & 19,0 bc CD & $18,0 \mathbf{c ~ A B}$ & $21,5 \mathbf{a} \mathbf{A B}$ & 20,5 ab CD \\
\hline PV & $21,0 \mathbf{a} \mathbf{B C}$ & $21,0 \mathbf{a} \mathbf{C D}$ & $20,0 \mathbf{a b B C D}$ & 18,0 b AB & 18,0 b D & 18,0 b EF \\
\hline $\mathrm{NN}$ & 22,5 a B & $21,0 \mathbf{a b} \mathbf{C D}$ & 19,5 b BCD & 17,0 c B & 21,0 ab $\mathbf{A B C}$ & $22,0 \mathbf{a} \mathbf{B C}$ \\
\hline MY & 25,0 a A & 18,5 c E & 21,5 b B & $18,0 \mathbf{c} \mathbf{A B}$ & 18,0 c D & $18,0 \mathbf{c ~ E F}$ \\
\hline TR & $17.0 \mathrm{~d} D$ & 23.0 a BC & 20.0bc BCD & $18,5 \mathbf{c d} \mathbf{A B}$ & $22,0 \mathbf{a b ~ A B}$ & $21,0 \mathbf{a b} \mathbf{C D}$ \\
\hline YG & 17,0 b D & 20,0 a DE & 18,0 ab D & 17,0 b B & 18,0 ab B & 17,0 b F \\
\hline $\mathrm{PN}$ & 25,0 a A & $21,0 \mathbf{c} \mathbf{C D}$ & $20,0 \mathbf{b c} \mathbf{B C D}$ & $19,0 \mathbf{c} \mathbf{A B}$ & 19,0 c CD & 22,0 b BC \\
\hline JV & 19,0 a CD & 18,0 a E & 18,0 a D & 20,0 a A & 20,0 a BCD & 19,5 a DE \\
\hline PV3 & $21,0 \mathbf{a} \mathbf{~ B C}$ & 20,0 ab DE & $21,0 \mathbf{a ~ B C}$ & $18,0 \mathbf{b} \mathbf{A B}$ & $21,0 \mathbf{a} \mathbf{A B C}$ & 18,0 b EF \\
\hline F01 & $25,0 \mathbf{a ~ A}$ & $25,0 \mathbf{b} \mathbf{A B}$ & 20,0 b BCD & $19,0 \mathbf{b} \mathbf{A B}$ & 23,0 a A & 25,0 a A \\
\hline F18 & 25.0 a A & 26,0 a A & 25.0 a A & 17.5 c B & $21,5 \mathbf{b} \mathbf{A B}$ & 24,0 a AB \\
\hline
\end{tabular}

$$
\mathrm{CV}=5 \%
$$

Médias seguidas pela mesma letra minúscula, na linha, e pela mesma letra maiúscula na coluna, não diferem estatisticamente, entre si, pelo teste de $t$ - Student, ao nível de $5 \%$ de probabilidade. Variedades: PA-Prata Anã; PV-Pacovan; NN-Nanicão; MY-Mysore; TR-Terra; YG-Yangambi; PN-Pioneira; JV-JV03-15; PV3-PV03-44; F01-Fhia-01; F18-Fhia-18; NC-Nanica.

Locais: Rg-Registro-SP; Ti-Tietê-SP; Ca-Cruz das Almas-BA; Ma-Manaus-AM; It-Itambé-PE. 


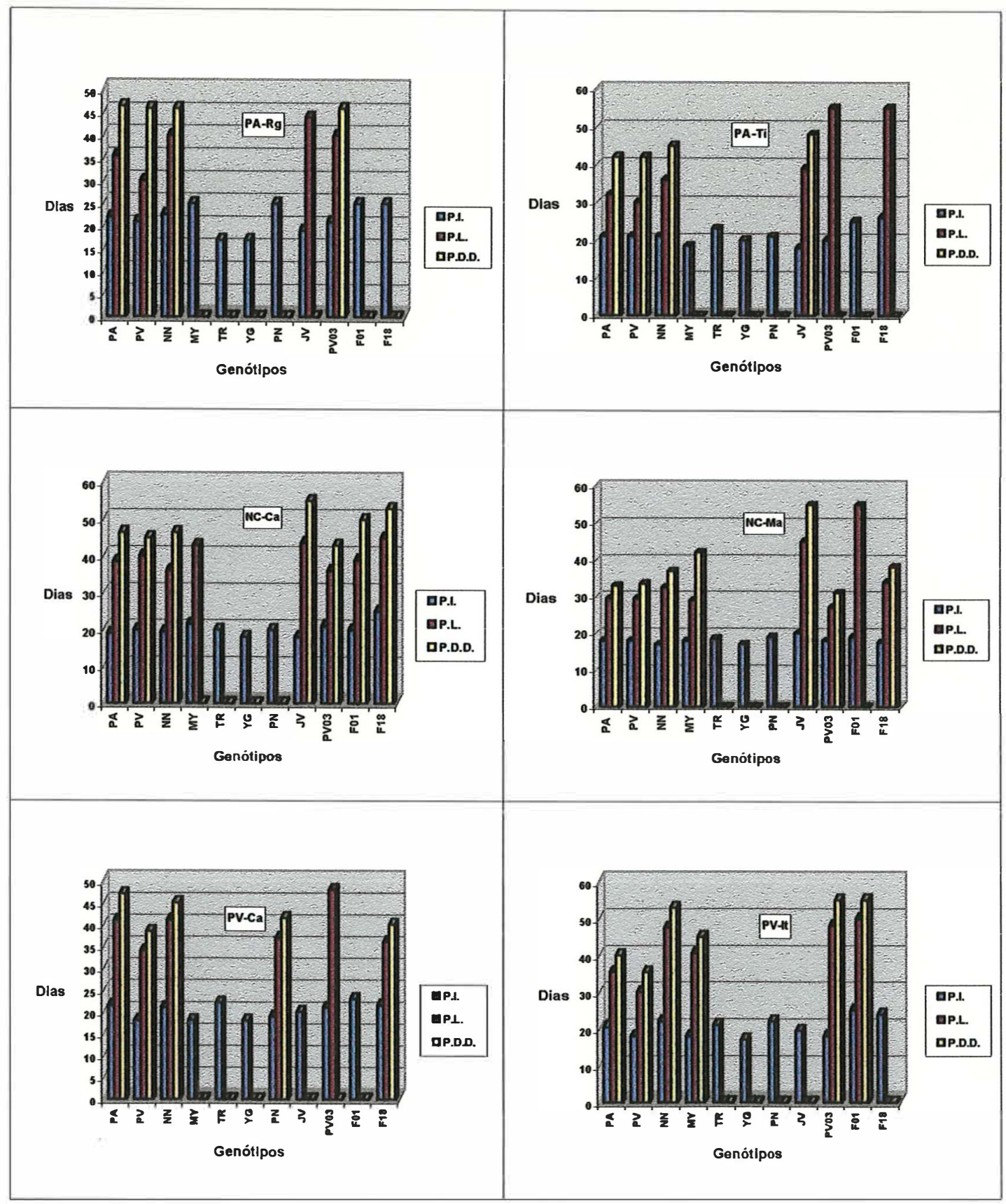

Fig. 1- Dados de período de incubação (P.I.), período de latência (P.L.) e período de desenvolvimento da doença (P.D.D.), obtidos mediante a inoculação de seis isolados de Mycosphaerella musicola sobre onze genótipos de bananeira, avaliados em condições de telado. Piracicaba, SP, 1997. 

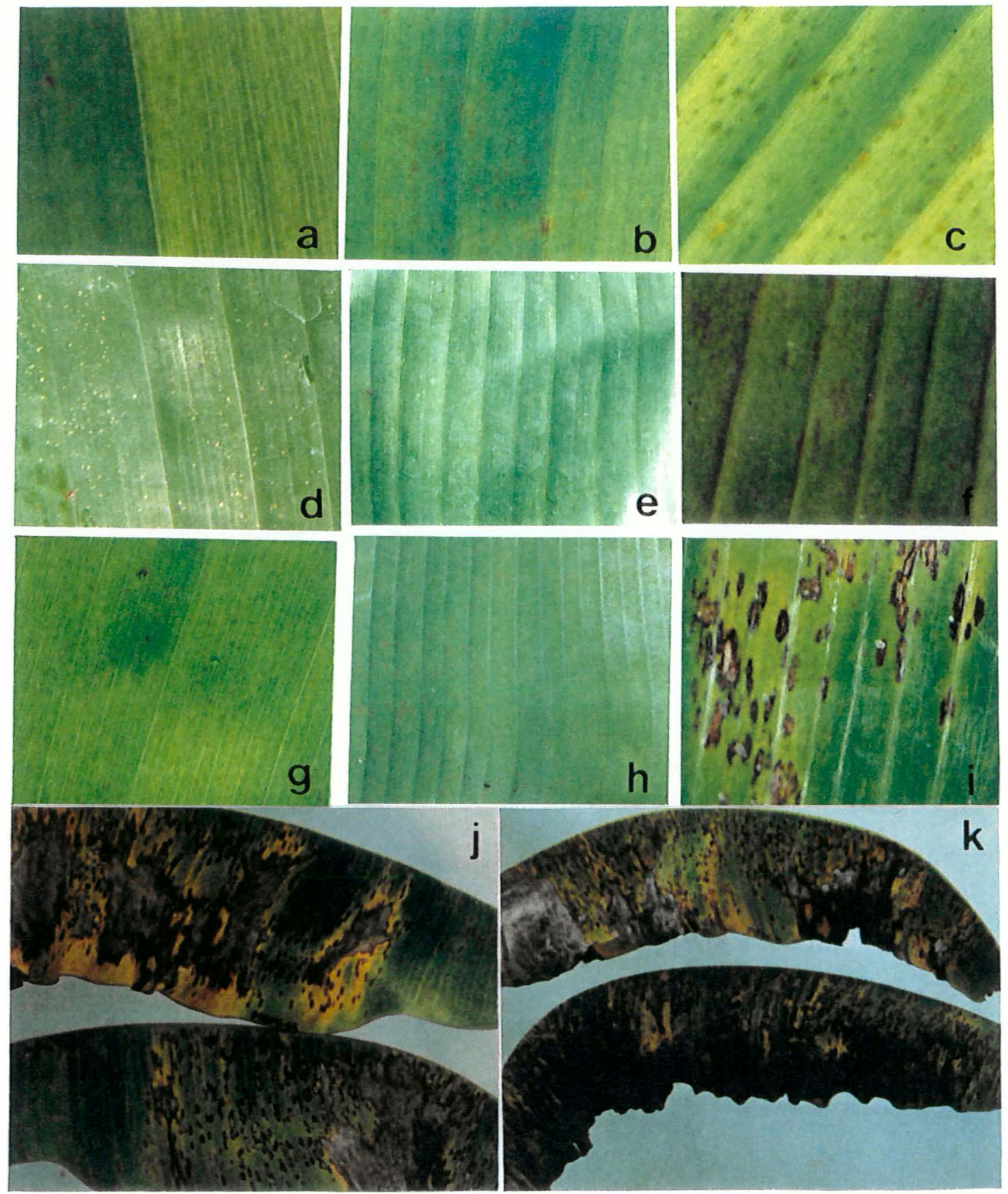

Fig. 2- Exemplos de algumas reações apresentadas pela interação genótipoisolado de Mycosphaerella musicola em variedades de banana. Sequiência a, b, c, em Yangambi; sequiência d, e, f, em Terra; seqüência g, h, i, em Pioneira e seqüência j, k, em Pioneira e Mysore, respectivamente. São reações do tipo hipersensível (Yangambi e Terra), alta resistência (Terra e Pioneira) e suscetível (Pioneira e Mysore). 


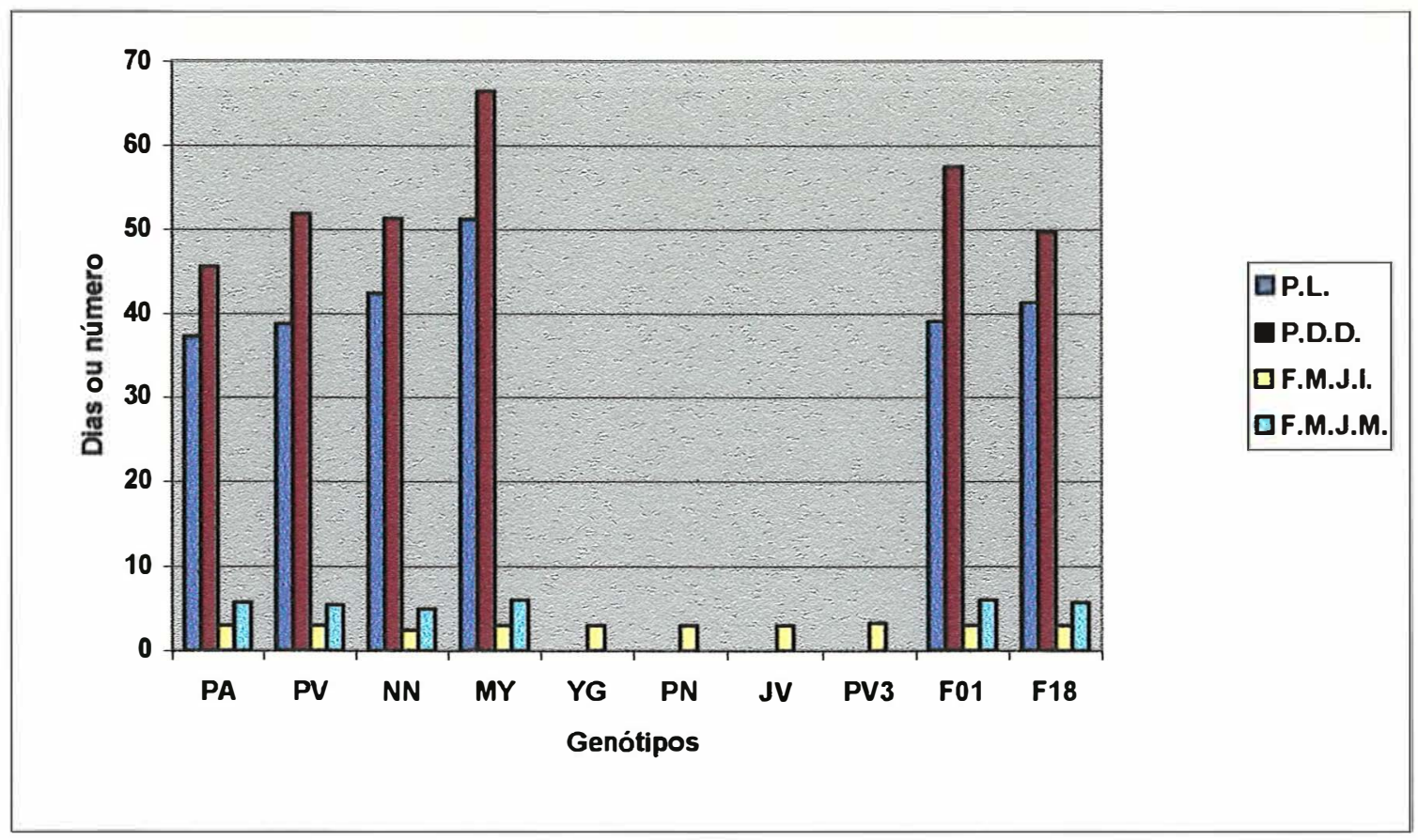

Fig. 3- Dados de período de latência (P.L.), período de desenvolvimento da doença (P.D.D.), folha mais jovem infectada (F.M.J.I.) e folha mais jovem manchada (F.M.J.M.), obtidos na avaliação de campo, sob condição de infecção natural, no município de Tietê-SP, com dez genótipos de bananeira (PA- Prata Anã, PV- Pacovan, NN- Nanicão, MY- Mysore, YG- Yangambi, PN- Pioneira, JV- JV03-15, PV3- PV03-44, F01- Fhia-01 e F18- Fhia-18). 


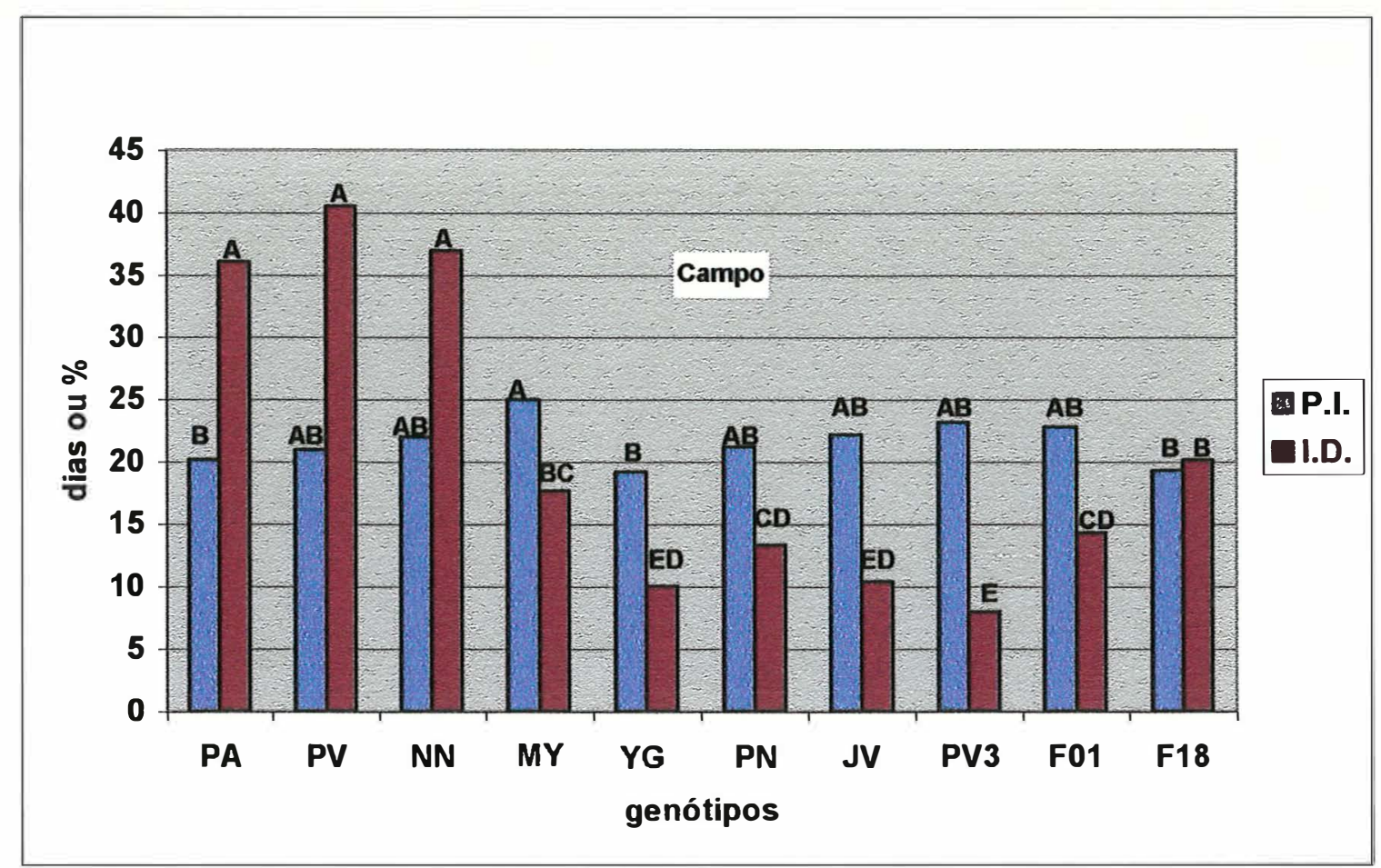

Fig. 4- Dados de período de incubação (P.I.) em dias e índice de doença (I.D.) em $\%$, obtidos em condições naturais de infeç̧ão a campo, no município de Tietê, SP, avaliando dez genótipos de bananeira (PA- Prata Anã, PV- Pacovan, NNNanicão, MY- Mysore, YG- Yangambi, PN- Pioneira, JV- JV03-15, PV3- PV0344, F01- Fhia-01 e F18- Fhia-18). As médias seguidas pelas mesmas letras não diferem, estatisticamente entre si, pelo teste de Tukey ao nível 0,05 de probabilidade. 


\section{4- DISCUSSÃO}

\subsection{1- Experimento em telado}

A discussão dos dados das Tabelas 1, 2, 3 e das Figuras 1 e 2, será feita, inicialmente, considerando cada genótipo separadamente, uma vez que seria dificil enfocar um conjunto de dados que envolvem a interação de onze genótipos de bananeiras com seis isolados de M. musicola. Comentários gerais serão feitos posteriormente.

\section{Prata Anã (PA)}

É uma variedade triplóide (AAB), considerada suscetível ao mal-deSigatoka (Dantas et al., 1993), em função de observações de campo. Conforme esperado, comportou-se como tal em relação a todos os isolados, os quais não mostraram variação em virulência, mas apenas em agressividade, conforme definido por Van der plank (1968).

\section{Pacovan (PV)}

Embora seja considerada uma variedade suscetível à Sigatoka amarela (Dantas et al., 1993), pode-se observar a ocorrência de interação diferencial (Tabelas 1 e 2), comportando-se como medianamente suscetível em relação ao isolado PA-Rg. Este isolado foi obtido sobre 'Prata Anã', no município de Registo - SP, região tradicionalmente produtora de bananas do grupo AAA e, recentemente, começou a cultivar a Prata $A$ nã $(\mathrm{AAB})$, possivelmente não apresentando ainda isolados perfeitamente adaptados à 'Pacovan', podendo assim justificar este resultado. 
Nanicão (NN)

Pertencente ao grupo AAA, também considerada suscetível à Sigatoka amarela (Dantas, et al.,1993 ; Simmonds 1966), esta cultivar apresentou surpreendente variabilidade em relação aos isolados, diferindo inclusive das suscetíveis 'Prata Anã' e 'Pacovan' (Tabelas 1 e 2), ao apresentar comportamento medianamente suscetível a dois isolados (PV-Ca e PV-It). Coincidentemente são isolados provenientes da Região Nordeste, onde predominam, com larga vantagem, as cultivares do grupo $\mathrm{AAB}$ como a Prata, Prata Anã e Pacovan. Isto poderia justificar a seleção de raças menos adaptadas ao 'Nanicão', uma vez que o fenômeno da coevolução (Camargo, 1995) tenderia a atuar no sentido das cultivares $\mathrm{AAB}$. Outro aspecto é que o Brasil, como um todo, tem um maior percentual das variedades cultivadas pertencentes ao grupo $\mathrm{AAB}$, direcionando, desta forma, o desenvolvimento de raças adaptadas às variedades deste grupo.

\section{Mysore (MY)}

É uma variedade do grupo $\mathrm{AAB}$ com pouca tradição de cultivo no Brasil. É considerada resistente a Sigatoka amarela (Dantas et al., 1993). Observando os resultados, porém, vê-se que a resistência não se estende a todas as raças de $P$. musae, comportando-se como suscetível aos isolados NC-Ma e PV-It (Tabelas 1 e 2). O número de lesões obtidas para os referidos isolados, não é condizente com a severidade final da doença, que foi semelhante à apresentada pelas suscetiveis PA, PV e NN. Observando, porém, a Figura 1 percebe-se que os valores do período de latência (P.L.) e período de desenvolvimento da doença (P.D.D), na 'Mysore', são superiores. Isto indica que a referida variedade apresenta um maior nível de resistência horizontal do que as suscetíveis, o que retardou o 
desenvolvimento das lesões e propiciou a baixa freqüência à época da avaliação. A associação das duas formas de resistência é, segundo Van Der Plank (1968), o normal na natureza.

\section{Terra (TR)}

É um plátano de grupo $\mathrm{AAB}$, bastante cultivado no Norte e Nordeste do Brasil. No Recôncavo Baiano, observa-se que a variedade convive sempre com um determinado nível de doença, visível principalmente nas folhas mais velhas da planta. Isto pode indicar um bom nível de resistência horizontal, também referida por Nelson (1973) como resistência de campo, não específica, parcial ou uniforme, em que há resistência a colonização e crescimento do patógeno subsequente a penetração, não impedindo, contudo, que o ciclo seja completado. Os resultados obtidos, por outro lado, mostram um alto nível de resistência (Tabela 1 e 2), caracterizada por reações que incluem o tipo hipersensível (Fig. 2, seqüência c, d e e), também denominada resistência específica, não uniforme, vertical, de gene maior, em que o hospedeiro resiste ao estabelecimento do parasita, restringindo o sítio de infeç̧ão e o processo de infecção. Neste caso, enquadrar-se-ia na descrição de Nelson (1973) ou no fenótipo I - alta resistência - proposto por Fouré (1993). Contudo, a Tabela 2 mostra ausência de interação diferencial entre isolados e cultivar, que pelas definições de Van Der Plank (1968), indicaria uma resistência horizontal. Contudo, a variabilidade testada é muito pequena para tal conclusão. Acredita-se que seja quase impossível provar que uma determinada resistência é horizontal, exatamente pela impossibilidade de se testar todos os variantes do patógeno (Eskes, 1980). Quanto ao alto nível da resistência apresentada, que poderia indicar uma resistência de genes fortes, hoje se sabe que a resistência horizontal pode ter uma expressão de quase imunidade ou de uma reação similar à da resistência vertical (Eskes, 1980). É o caso, por 
exemplo, da Puccinia striiformis em trigo, onde genes menores em conjunto, conferem alta resistência (Simons, 1972) ou em batata-Phythothora, onde altos níveis de resistência horizontal conferem reação tipo hipersensibilidade (Thurston, 1971).

\section{Yangambi (YG)}

Pertence ao grupo AAA, onde também se encontra a 'Nanicão'. Os resultados, tais como os observados para 'Terra', mostram um alto nível de resistência, apresentando comportamento uniforme em relação a todos os isolados (Tabela 1 e 2; Fig. 1). Na Fig. 2, seqüência a, b, c pode-se observar as reações tipo hipersensível. São válidos, portanto, para esta variedade, considerando a ausência de interação isolado-cultivar e o alto nível de resistência da mesma, os comentários apresentados para a cultivar Terra. Em relação à Sigatoka negra (Mycosphaerella fijiensis), a mesma tem sido avaliada e também classificada como alta resistência, caracterizada por reações tipo hipersensibilidade (Fouré, 1982; Fouré et al. 1984; Fouré, 1985; Fouré, 1993), confirmando assim os resultados obtidos em relação à Sigatoka amarela. Porém, diante da variabilidade demonstrada por $P$. musae, é importante que um maior número de isolados, incluindo a maior variedade possível, sejam testados sobre 'Yangambi', uma vez que a mesma está sendo avaliado pelo CNPMF (Soares Filho et al. 1990), com amplas possibilidades de ser recomendada para cultivo no Brasil.

\section{Pioneira (PN)}

É uma variedade tetraplóide (AAAB), oriunda do cruzamento entre 'Prata Anã' (AAB) e Lidi (AA). Foi avaliada e recomenda pelo CNPMF como resistente à Sigatoka amarela com base apenas em avaliações de campo (Dantas et al.1993 ; 
Shepherd et al., 1992). Os dados das Tabelas 1 e 2 e Figura 3 mostram, entretanto, o comportamento diferenciado desta cultivar em relação ao isolado PV-Ca. É um caso típico de resistência vertical (Van Der Plank, 1968) onde a Pioneira mostra uma alta resistência aos isolados PA-Rg, PA-Ti, NC-Ca, NC-Ma e PV-It encaixando-se nos conceitos de Nelson (1973) e na classificação de Fouré (1993), como portador de alta resistência, porém a mesma foi quebrada pelo isolado PV-Ca. Observando o gráfico PV-Ca, da figura 3, vê-se que a resistência uma vez quebrada, a variedade se comporta como as suscetíveis 'Prata Anã' e 'Pacovan'. Isto pode ser evidenciado pelos parâmetros período de latência (P.L.) e período de desenvolvimento da doença (P.D.D.), indicando a presença de um baixo nível de resistência horizontal, melhor observada com a quebra da vertical.

Na Figura 2, pode-se observar na seqüência $g, h$, i e $j$, os tipos de interações observadas nesta cultivar, caracterizando reações desde alta resistência (Fig. $4 \mathrm{~g}, \mathrm{~h}$ ) contra os isolados PA-Rg, PA-Ti, NC-Ma e PV-It, até alta suscetibilidade (Fig. 4 i e J), contra o isolado PV-Ca. Vale destacar que este isolado foi obtido na área experimental do CNPMF, em Cruz das Almas - BA sobre a cultivar Pacovan. A variedade Pioneira, obtida pelo programa de melhoramento de banana em desenvolvimento no CNPMF (Shephard et. al. 1992), onde foi avaliada, em condições naturais de infecção, por cerca de dez anos. Durante esse tempo sempre apresentou um certo nível de doença, no campo do CNPMF. Acreditava-se tratar de algum tipo de resistência vertical incompleta, ou mesmo uma resistência horizontal. Com a comprovação, no capítulo I, de uma alta variabilidade dentro da espécie $M$. musicola, passa-se a entender que a presença constante de níveis baixos de doença, na variedade Pioneira, se devia a uma baixa população do isolado PV-Ca no ambiente, e não a um tipo de resistência horizontal ou vertical incompleta. O resultado obtido mostra a vulnerabilidade e, acima de tudo, a inconveniência de se trabalhar com a resistência vertical em uma cultura perene e de clima tropical como a bananeira. 
A avaliação de genótipos dentro do programa de melhoramento deve ser repensada em função da variabilidade do patógeno e da necessidade de se buscar uma resistência durável, para os problemas fitossanitários desta cultura.

\section{JV03-15 (JV)}

É um híbrido tetraplóide $(\mathrm{AAAB})$, oriundo do cruzamento entre 'Prata Java' (AAB) e Calcuttá (AA). Apesar das diferenças estatísticas mostradas na análise de freqüência de lesão (Tabela 1), o avanço da doença não é confirmado na análise da severidade (Tabela 2), caracterizando assim a ausência de interação diferencial entre hospedeiro e patógerc. Destaca-se novamente um alto nível de resistência, comparável àqueles apresentados pelos genótipos Terra e Yangambi, tomando válidos, portanto, os comentários apresentados para a cultivar Terra. Destaca-se que em relação aos isolados PA-Rg, PA-Ti, NC-Ca e NC-Ma (Fig. 1, gráficos PA-Rg, PA-Ti, NC-Ca e NC-Ma), o período de latência (P.L.) e/ou período de desenvolvimento da doença (P.D.D.), foram completados, porém, apenas um pequeno grupo de lesões atingiram a fase de mancha, refletindo na baixa severidade (Tabela 2). Possivelmente seja uma indicação de que a resistência vertical desde genótipo vem acompanhado de um alto nível de resistência horizontal, neste caso, caracterizada por drástica redução na freqüência de lesão. Conforme destacado por Van Der Plank (1968), o mais comum é a associação das duas formas de resistência num mesmo genótipo, a quebra da vertical coloca em ação a horizontal.

\section{PV03-44 (PV3)}

É um híbrio tetraplóide (AAAB), oriundo do cruzamento entre 'Pacovan' (AAB) e Calcuttá (AA). Nas avaliações foi suscetível em duas interações (NC-Ca 
e NC-Ma ) e resistente nas demais (Tabelas 1 e 2). Evidencia-se mais uma vez, a presença de uma resistência tipicamente vertical (Van Der Plank, 1968 e 1963), caracterizada pela presença da interação diferencial significativa entre genótipo e isolados.

Observando-se a Figura 1, no entanto, percebe-se que este genótipo pode ter comportamento diferente dos demais, uma vez que, em todas as interações, as lesões passaram das fases de estrias para manchas sem contudo configurar uma quebra da resistência. Nos casos em que a resistência foi realmente quebrada (Fig. 1, gráficos NC-Ca e NC-Ma), o comportamento do genótipo foi semelhante aos dos suscetíveis (PA, PV e $\mathrm{NN}$ ), indicando a presença de baixo nível de resistência horizontal no mesmo, conforme também observado para 'Pioneira'. Somente un maior número de avaliações, envolvendo maior variabilidade do patógeno e outros parâmetros como taxa de esporulação e período de esporulação (Eskes, 1980), poderão ajudar a entender melhor o comportamento deste genótipo.

\section{FHIA-01 (F01)}

Este genótipo, um híbrido tetraplóide (AAAB), obtido do cruzamento da 'Prata Anã' com diplóide AA, foi introduzido da Fundação Hondurenha de Investigações Agricolas (FHIA), tendo em vista sua alta resistência à Sigatoka negra e boas características agronômicas (Jones, 1994). Na área do CNPMF, a severidade da Sigatoka amarela no mesmo tem sido, comparativamente, maior do que a observada em 'Pioneira'. É uma indicação de que o controle genético das duas doenças são diferentes. Neste ensaio, o nível de severidade classifica-o como de resistência intermediária em relação ao isolado NC-Ca e como resistente em relação aos demais (Tabela 2). Vale salientar que NC-Ca, foi obtido na área do CNPMF, em Cruz das Almas-BA, justificando, pelo menos em parte, o nível 
de doença ali apresentado. Seguindo os conceitos de Van der Plank (1968), a resistência é vertical, tendo em vista a presença da interação diferencial entre isolados do patógeno e o referido genótipo. Porém, há que se pesquisar, para melhor conhecimento e caracterização deste genótipo, a presença da resistência horizontal no mesmo.

\section{FHIA-18 (F18)}

É também um tetraplóide (AAAB), com a mesma origem do FHIA-01 e, para o qual são também válidas as observações feitas na área do CNPMF em relação à Sigatoka amarela. Nos testes de telado, os isolados NC-Ca e PV-Ca, provenientes da área experimental do CNPMF, foram virulentos sobre este genótipo (Tabelas 1 e 2), justificando observações anteriores. Fenotipicamente é classificado como de resistência intermediária frente a NC-Ca, PV-Ca e PA-Ti. Já em relação a NC-Ma, comportou-se como suscetível, sendo resistente aos demais (Tabelas 1e 2). Houve, portanto, interação diferencial significativa entre 0 genótipo e os isolados, com variação fenotípica, alterando entre resistente, intermediário e suscetível.

Analisando, porém, a Figura 1, gráficos PA-Ti, NC-Ca, NC-Ma e PV-Ca, percebe-se uma atuação em níveis diferenciados, dos parâmetros período de latência e período de desenvolvimento da doença, sugerindo uma participação ativa da resistência horizontal nos resultados obtidos. Contudo, é um assunto a ser estudado em mais detalhes para obtenção de informações mais seguras. Outrossim, a presença da resistência horizontal é uma característica altamente desejável em bananeira.

Em relação ao período de incubação, o mesmo não é considerado um parâmetro importante na avaliação da resistência à Sigatoka negra (Fouré, 1985). Certamente, também, não o é na avaliação da Sigatoka amarela. Porém, 
estatisticamente, há diferenças entre os períodos de incubação, tanto dentro de isolados como dentro de cultivares (Tabela 3). Mesmo considerando sua não importância como parâmetro de avaliação da resistência, o mesmo poderá ser útil como indicador da agressividade do isolado. NC-Ma foi o mais agressivo dos isolados. Observe que os períodos de incubação obtidos foram, no geral, menores do que os demais. Outro aspecto que poderá ser indicado pelo período de incubação é a magnitude da resistência ou, possivelmente, a natureza da resistência. Resistência de genes fortes, manifestada na forma de hipersensibilidade (Nelson, 1973 ; Fouré, 1993), parece apresentar menor período de incubação. Tal consideração é suportada pelas reações apresentadas pela 'Yangambi' (Tabelas 1, 2, 3 e Fig. 3 e 4).

Provavelmente ainda, incrementos no período de incubação podem estar associados a incrementos nos níveis de resistência horizontal, o que seria lógico. Observe, por exemplo, os genótipos FHIA-01 e FHIA-18 (Tabela 3), sobre os quais admite-se a hipótese de níveis maiores de resistência horizontal e sobre os quais os períodos de incubação são mais longos. Estas hipóteses somente poderão ser comprovadas, entretanto, com novas e maiores observações.

\subsection{2- Experimento de campo}

Diante dos resultados observados no capítulo I, que mostram uma alta variabilidade entre isolados de M. musicola, a avaliação de campo perde a sua importância, uma vez que, os genótipos são expostos a uma restrita variabilidade do patógeno ou, simplesmente, a níveis muito baixos de inóculo, podendo, nestes casos, superestimar a resistência. $O$ inóculo presente na área experimental originou-se basicamente das cultivares Prata Anã e Nanicão, não se conhecendo, entretanto, a variabilidade presente na área. 
Os dados mostram claramente dois grupos de médias de acordo com os dados de índice de doença (Fig. 4): as médias das cultivares suscetíveis, compostas pelos genótipos Prata Anã, Pacovan e Nanicão e, das resistentes, compostas pelos genótipos Mysore, Yangambi, Pioneira, JV03-15, PV03-44, FHIA-01e FHIA-18. A análise fenotípica da resistência destaca os genótipos Yangambi (YG), Pioneira (PN), JV03-15 (JV) e PV03-44 (PV3) com alto nível de resistência, nos quais, os sintornas não passaram da fase de estrias, caracterizando-se dentro de um grupo de alta resistência, conforme definido por vários autores (Simmonds, 1966; Vakili, 1968 ; Meredith \& Lawrence, 1970 ; Fouré, 1993 ; Jones, 1995). Já os genótipos Mysore (MY), FHIA-01 (F01) e FHIA-18 (F18), embora estejam insezidos no grupo de genótipos resistentes, estatisticamente diferentes das testemunhas suscetíveis (PA, PV e NN), chegaram a completar o desenvolvimento da doença, fato que os difere do grupo anterior (Figs 3 e 4). De acordo com a proposição de Fouré (1993), seriam incluídos no fenótipo II, caracterizado como resistência parcial, onde as plantas apresentariam um baixo desenvolvimento da doença, propiciando um grande número de folhas funcionais por ocasião da colheita, mas havendo, por outro lado, a reprodução sexual e assexual do patógeno. O autor acredita tratar-se de um caráter quantitativo associado a vários genes.

Em relação ao período de incubação (Fig. 4), tal como se observou em telado, aparecem diferenças estatísticas, porém, com pouca ou nenhuma importância na avaliação da resistência, conforme destacado para Sigatoka negra por Fouré (1985). Observações futuras, no entanto, podem confirmar suspeitas anteriores de que o período de incubação possa funcionar como indicador da agressividade de isolados e/ou da magnitude da resistência.

Os parâmetros folha mais jovem infectada (F.M.J.I.) e folha mais jovem manchada (F.M.J.M.), representados na figura 3, não merecem maior atenção, uma vez que, as diferenças não são consideráveis. 
Os parâmetros período de latência (P.L.) e período de desenvolvimento da doença (P,D.D.), de grande importância na avaliação da resistência horizontal, porque dão uma idéia da velocidade de desenvolvimento da epidemia, mais uma vez indicam, concordando com as informações obtidas em telado (Fig. 1), que a Mysore deve ser portadora de um maior nível de resistência horizontal do que os suscetíveis 'Prata Anã', 'Pacovan' e 'Nanicão'. Quanto aos genótipos FHIA-01 e FHIA-18, os dados de P.L. e P.D.D. mostrados na figura 1 não evidenciam diferenças em relação às variedades suscetíveis (PA, PV e NN). Entretanto, a severidade observada através do índice de doença (Fig. 4), diferencia-os das variedades suscetíveis, tornando válidas as hipóteses levantadas nos testes de telado acerca da resistência horizontal presente nestes genótipos. $O$ baixo índice de doença denota redução na freqüência de lesões, um parâmetro importante na avaliação da resistência horizontal (Eskes, 1980).

\section{-Comentários gerais}

De modo geral, o que se pode dizer em relação aos genótipos avaliados, tanto em condições de telado, como no campo é que há o predomínio de uma resistência de tipo vertical, conforme conceitos apresentados por Van Der Plank (1963 ; 1968), segundo o qual a resistência vertical é caracterizada pela ocorrência da interação diferencial entre patógeno e hospedeiro, indicada pela análise de variância. Isto pode ser observado nos dados das Tabelas 1 e 2 , obtidos em telado. Ainda segundo Van Der Plank (1968), provavelmente a resistência vertical nunca ocorra desacompanhada da resistência horizontal, embora, esta última possa, algumas vezes, ocorrer sozinha. Com base nesta observação acredita-se que níveis variados de resistência horizontal acompanham a resistência vertical presente nos genótipos. Tal observação pode ser feita apenas naqueles genótipos onde a resistência vertical foi quebrada. Nesse caso, 
observando-se os dados de período de latência (P.L.) e período de desenvolvimento da doença (P.D.D.) (Fig. 1 e 3), é possivel perceber variações nestes parâmetros, retardando o avanço da doença. Para conclusões mais seguras, entretanto, é importante que dados como taxa de progresso da doença, taxa de crescimento das lesões, taxa de esporulação sejam avaliados (Eskes, 1980 ; Fry, 1982; Bergamim Filho \& Amorim, 1996).

A acomodação dos genótipos avaliados em classes fenotípicas tem sido utilizada (Simmonds, 1966; Vakili, 1968; Meredith \& lawrece, 1970; Fouré, 1993; Jones 1995), tanto em avaliações de resistência à Sigatoka amarela como negra. Entretanto, foram avaliações que não consideraram a variabilidade patogênica no seu contexto. Neste caso, qualquer classificação desta natureza, teria que considerar o isolado utilizado. Apenas os genótipo Yangambi, Terra e JV03-15, com alta resistência a todos os isolados, poderiam ser classificados sem restrição, dentro do fenótipo I, proposto por Fouré (1993), ou como extremamente resistente segundo Jones (1995), avaliando resistência à Sigatoka amarela.

A variabilidade patogênica dentro da espécie $M$. musicola, observada no capítulo I e, mais uma vez confirmada neste capítulo, sugere que futuras avaliações sejam realizadas em condições controladas e, considerando a maior variabilidade possível do patógeno, bem como a possibilidade de avaliar a resistência vertical e horizontal (Mourichon, 1994). Caso contrário, quebra de resistência, em curto período, como já ocorrido na 'Pioneira' lançada pelo CNPMF (Cordeiro et. al. 1993), continuará a ocorrer. A meta dos programas de melhoramento devem ser o desenvolvimento de variedades com resistência durável (Johnson, 1981; Fullerton \& Olsen, 1993), para não utilizar o termo horizontal, tal como proposto por Van der Plank (1963). O uso da resistência vertical, de característica efêmera, não coaduna com uma planta perene e de clima tropical como a bananeira (Robinson, 1976). 
Quanto às avaliações em condições de telado, não há evidências de problemas nos resultados. A experiência ora vivenciada, recomenda, entretanto, os seguintes cuidados na execução:

1-Uniformizar ao máximo possível a idade das folhas, de modo a evitar discrepâncias entre as observações. Preferencialmente, utilize a folha número um, para as avaliações, porque, embora Jacome \& Schuh (1992) afirmem que as folhas mais velhas da bananeira mostravam-se mais condutivas à infecção pela Sigatoka negra, isto não foi verdadeiro para a Sigatoka amarela, ou seja, informações anteriores de que as folhas mais novas da planta são mais suscetíveis à doença continuam válidas (Stover, 1972).

2-Se possível, não utilize a mesma planta em mais de uma observação, porque em casos de interações incompatíveis, a mesma poderá apresentar resistência adquirida, conforme observado no capítulo II, podendo levar a conclusões erradas nas avaliações posteriores.

3- Dar preferência para o trabalho em ambientes bem iluminados, uma vez que, a doença não se desenvolve bem em ambientes com baixa luminosidade, fato observado no capítulo I e enfatizado por Calpouzos (1966). 


\section{5- REFERÊNCIAS BIBLIOGRÁFICAS}

ALBUQUERQUE, P. S. B. Mycosphaerella musicola: produção de conídios in vitro; sensibilidade a fungicidas $e$ avaliação da resistência em mudas de cultivares de bananeiras (Musa spp. ). Piracicaba, 1993. 94p. Dissertação (M.S.) - Escola Superior de Agricultura "Luiz de Queiróz", Universidade de São Paulo.

BERGAMIN FILHO, A. \& AMORIM, L. Doenças de Plantas Tropicais: Epidemiologia e Controle Econômico, Editora Agronômica Ceres, São Paulo, 1996, 299p.

BRUN, J. La cercoporiose du bananier en Guinée. Étude de la phase ascosporée du Mycosphaerella musicola Leach, Paris, 1963, 196p. Thèse- Institut Français de Recherches Fruitières Outre Mer.

CALPOUZOS, L. Studies on the Sigatoka disease of bananas and its fungus pathogen. Atkins Garden and Research Laboratory, Cienfuegos, Cuba, 1955. 70p.

CALPOUZOS, L. Action of oil in the control of plant disease. An. Rev. Phytopath., v.4, p. 369-390, 1966.

CAMARGO, L. E. A. Mecanismos de variabilidade genética de agentes fitopatogênicos. IN: BERGAMIM FILHO, A. ; KIMATI, H. \& AMORIM, L. Manual de Fitopatologia volume 1: princípios e conceitos, Ed. Agronômica Ceres, São Paulo, cap. 23, p.455-469, 1995.

CARLIER, J.; GONZALES DE LEON, D.; MOURICHON, X. \& ZAPATER, M. F. Genetic diversity of Mycosphaerella fijiensis, causal agent of black leaf streak in banana. IN: GANRY, J. Breeding banana and plantain for resistance to diseases and pests. Proceedings, CIRAD and INIBAP, Montpellier, France, 1993, p.193-199. 
CARLIER, J.; MOURICHON, X.; GONZALES DE LEON, D.; ZAPATER, M. F.\& LEBRUN, M. H. DNA Restriction Fragment lengt Polimorphisms in Mycosphaerella species that cause banana leaf spot diseases. Phytopathology, v.84, p.751-756, 1994.

CORDEIRO, Z. J. M. ; DANTAS, J.L.L.; SILVA, S. DE O. e ; SHEPHERD, K. \& ALVES, E. J. "Pioneira"- Nova variedade de banana. Cruz das Almas, BA, Embrapa/CNPMF, Banana em Foco, 1993, 2p.

CORDEIRO, Z. J. M. \& KIMATI, H. Doenças da Bananeira (Musa spp) $\mathbb{N}$ : KIMATI, H. ; AMORIM, L. : BERGAMIM FILHO, A. ; CAMARGO, L. E. A. \& REZENDE, J. A. M. Manual de Fitopatologia, volume 2: Doenças das plantas cultivadas, Ed. Agronômica Ceres, São Paulo, cap. 13, p. 112136, 1997.

DANTAS, J. L. L. ; SHEPHRD, K. ; SOARES FILHO, W. dos S. et al. Programa de melhoramento genético da bananeira em execução no CNPMF/Embrapa-avanços obtidos. Cruz das Almas, BA, Embrapa/CNPMF, Documentos, 47, 1993. 42p.

DANTAS, J. L. L. ; SHEPHERD, K. ; SOARES FILHO, W. dos S. et al. Citogenética e melhoramento genético da bananeira (Musa spp). Cruz das Almas, BA, Embrapa/CNPMF, Documentos, 48, 1993 a, 61p.

ESKES, A. B. Bases genéticas da resistência horizontal a patógenos em plantas. Ciência e cultura, v.32, p.1464-1472, 1980.

ESCALANTE, J. V. Early evaluation of Musa genetic material from Embrapa against black Sigatoka. Informe final, CATIE, Turrialba, 1993. (Relatório Técnico apresentado à Embrapa/CNPMF pelo CATIE).

FOURÉ, E. Les cercosporioses du bananier et leurs traitements. Comportament des variétés. Etude de la sensibilité variétale des bananiers et plantains à Mycosphaerella fijiensis Morelet au Gabon ( maladie des raies noires ). IIncubation et évolution de la maladie. Fruits, v.37, p.749-766, 1982. 
FOURÉ, E. ; GRISONI, M. \& ZURFLUH, R. Les cercosporioses du bananier et leurs traitements. Comportement des variétés. Etude de la sensibilité variétale des bananiers et plantains à Mycosphaerella fijiensis Morelet et de quelques caractéristiques biologiques de la maladie des raies noires au Gabon. Fruits, v.39, p.365-378, 1984.

FOURÉ, E. Les cercosporioses du bananier et leurs traitements. Comportement des variétés. Etude de la sensibilité variétale des bananiers et plantains à Mycosphaerella fijiensis Morelet au Gabon (maladie des raies noires). (suite III). Fruits, v.40, p.393-399, 1985.

FOURÉ, E. \& LESCOT, T. Variabilité génétique des Mycosphaerella inféodés au genre Musa. Mise en évidence de la présence au Cameroun sur bananiers et plantains d'une cercosporiose (Mycosphaerella musicola) au comportement pathogène atypique. Fruits, v.43, p. 407-515, 1988.

FOURÉ, E. Characterization of the reactions of banana cultivars to Mycosphaerella fijiensis Morelet in Cameroon and genetics of resistance. $\mathbb{N}$ : GANRY, J. (Ed.) Breeding banana and plantain for resistance to disease and pests. Proceedings, Montpellier, France, CIRAD-FLOR, 1993, p.159170.

FUlLERTON, R. A. \& OLSEN, T. L. Patogenic diversity in Mycosphaerella fijiensis Morelet. IN: GANRY, J.(Ed.) Breeding banana and plantain for resistance to diseases and pests. Proceedings, Montpellier, France, CIRADFHLOR, 1993, P.201-211.

FRY, W. E. Principles of plant disease management. Orlando, Florida, Academic Press, INC., 1982, 377p.

GALINDO, J. J.; GONZALEZ, M.; ESCALANT, J. V. \& JARAMILO, R. Evaluation of the resistance to Mycosphaerella fijiensis of germoplasm in the international Musa testing program. CATIE, Turrialba, 1990. (Relatório Técnico apresentado à Embrapa/CNPMF pelo CATIE). 
GAUHL, F. Epidemiology and ecology of black Sigatoka (Mycosphaerella fijiensis Morelet) on plantain and banana (Musa spp) in Costa Rica, Central America. Inibap, Montpellier, France, 1994,120p.

GOOS, R. D. \& TSCHIRCH, M. Greenhouse studies on the Cercospora leaf spot of banana. Trans. Brit. Mycol. Soc. v.46, p.321- 330, 1963.

ISSA, E. A cercosporiose da bananeira. O Biológico, v.29, p.65-73, 1953.

JACOME, L. H. \& SCHUH, W. Effects of leaf wetness duration and temperature on development of black Sigatoka disease on banana infected by Mycosphaerella fijiensis var. difformis. Phytopathology, v.82, p.515-520, 1992.

JACOME, L. H. \& SCHUH, W. Effect of temperature on growth and conidial production in vitro, and comparison of infection and aggressiveness in vivo among isolates of Mycosphaerella fijiensis var.difformis. Trop. Agric., v.70, p.51-59, 1993.

JACOME, L. H. \& SCHUH, W. Spore production and artificial inoculation techniques for Mycosphaerella fijiensis var. difformis. Trop. Agric., v.70, p. 33-38, 1993a.

JONES, D. R.(ed.) The improvement and testing of Musa: a global partnership. Proceedings of the first global conference of the international Musa testing program held at FHIA, Honduras 27-30 april 1994, Inibap, France, 1994. 303p.

JONES, D. R. Rapid assessment of Musa for reaction to Sigatoka disease. Fruits, v.50, p. 11-22, 1995.

JOHNSON, R. Durable resistance: Definition of, genetic control, and attainment in plant breeding. Phytopathology, v.71, p.567-568, 1981. 
MARIM VARGAS, D. \& ROMERO CALDERÓN, R. El combate de la Sigatoka negra. Boletin, $\mathrm{n}$. 4, CORBANA, Departamento de Investigaciones, San José, Costa Rica, /1989?/, 21 p.

MARTINEZ, J. A. O mal-de-Sigatoka e sua importância econômica para a bananicultura do Estado de São Paulo. O Biológico, v.66, p.271-280, 1970.

MEREDITH, D. S. \& LAWRENCE, J. S. Black leaf streak disease of bananas (Mycosphaerella fijiensis): Suscetibility of cultivars. Trop. Agric., v.47, p.275-287, 1970.

MONNIER, E. Variabilité génétique des Mycosphaerella inféodés au genre Musa. Essai de mise en évidence d'échanges d'informations par fusion de cellules végétatives. Fruits, v.41, p.15-23, 1986.

MOURICHON, X.; PETER, D. \& ZAPATER, M.F.e. Inoculation expérimentale de Mycosphaerella fijiensis Morelet sur de jeunes plantules de bananiers issues de culture in vitro. Fruits, v.42, p.195-198, 1987.

MOURICHON, X. Mycosphaerella fijiensis: Diversity and possibilities for the early screening of germoplasm for resistance. IN: JONES, D. R. (ed.) The improvement and testing of Musa: a global partnership. Proceedings of the first global conference of the International Musa Testing Program held et FHIA, Honduras, 27-30 april 1994, Inibap, France, 1994. p.47-53.

NELSON, R.R.(ed.) Breeding plants for disease resistance- concepts and aplications. Univesity Park and london, The Pensylvania state University Press, 1973, 401p.

ROBINSON, R. A. Plant pathossistems. Springer Verlag, Berlim, Heidelberg, New York, 1976, 184p.

SAS USER'S GUIDE: STATISTIC, v.6 edition. SAS Institute Inc. 956p, 1994.

SHEPHERD, K. Genetic improvement of bananas in Brasil: aspects related to resistance to the genus Mycosphaerella. IN: FULLERTON, R. A. \& STOVER, R. H. (ed.) Sigatoka leaf spot of bananas. Proceedings of an 
international workshop held at San José, Costa Rica, 1989. Inibap, Montpellier, France, 1990. p. 243-251.

SHEPHERD, K.; SILVA, S. de O. e; DANTAS, J. L. L.; CORDEIRO, Z. J. M. \&

SOARES FILHO, W. dos S. Hibridos tetraplóides de bananeira avaliados no CNPMF. Rev. Bras. Frutic., v.14, p.33-39, 1992.

SHILLINGFORD, C. A. Varietal susceptibility of bananas to infection by Mycosphaerella musicola in sprayed and unsprayed plots. Trop. Agric., v.52, p.157-165, 1974.

SIMMONDS, J. H. Banana leaf spot. Quenl. Agric. J., v.39, p.21-40, 1933.

SMONDS, N. W. bananas, 2a ed.,London, Longman, 1966. 512p.

SIMONS, M. D. Polygenic resistance to plant diseases and its use in breeding resistant cultivars. J. Environ. Quality, v.1, p.232-239, 1972.

SOARES FILHO, W. dos S.; ALVES, E. J.; CORDEIRO, Z. J. M.; CUNHA, M.

A. P. da; SHEPHERD, K.; DANTAS, J. L. L. \& BORGES, A. L. Programa de Pesquisa de Banana e "Plátano" em execução no CNPMF-Embrapa. Cruz das Almas, BA, Embrapa-CNPMF, Documentos, 28. 1990, 15p.

STAEL, G. Notes on cercospora leaf spot of bananas (Cercospora musae). Trop. Agric., v.14, p. 257-264, 1937.

STAKMAN, E. C. \& CHRISTENSEN The problem of breeding resistant varieties. IN: HORSFALL, J. G. \& DIMOND, A. E. PLANT PATHOLOGY: an advanced treatise, New York, Academic Press, v. III , cap.14, 1960, p.567-625.

STOVER, R. H. A proposed international scale for estimating intensity of banana leaf spot (Mycosphaerella musicola). Trop. Agric., v.48, p. 185-196, 1971.

STOVER, R. H. Banana, plantain and abaca disease. Commonwealth Mycological Institute, England, 1972. 316p.

THURSTON, H. D. Relationship of general resistance: late blight of potato. Phytopathology, v.61, p.620-626, 1971. 
VAN DER PLANK, J. E. Disease resistance in plants, New York, Academic Press, 1968, 206p.

VAN DER PLANK, J. E. Plant Disease: Epidemics and control. New York, Academic Press, 1963,

VAKILI, N. G. Responses of Musa acuminata species and edible cultivars to infection by Mycosphaerella musicola. Trop. Agric., v.45, p.13-22, 1968. 


\section{6- CONCLUSÕES GERAIS}

Diante dos resultados obtidos nos experimentos de campo e telado, podese concluir que:

- Mycosphaerella musicola apresenta uma alta variabilidade patogênica, ao nível de virulência, quando os isolados são inoculados sobre um grupo de variedades diferenciadoras, observando-se ainda variações em agressividade entre os isolados testados;

- Plantas das variedades de banana Nanicão e Prata Anã desenvolveram resistência sistêmica induzida, de alta magnitude, permanecendo ativa por cerca de quatro meses contra o mal-de-Sigatoka, quando inoculadas com raças incompatíveis de Mycosphaerella musicola e ainda, no caso de 'Nanicão', quando inoculadas com isolados compatíveis, mas fazendo a incubação em ambiente desfavorável ao desenvolvimento da doença;

- A resistência observada nos diferendes genótipos de bananeira avaliados é predominante vertical e fenotipicamente, se enquadram desde alta suscetibilidade até alta resistência, esta última caracterizada por reações tipo hipersensibilidade e/ou paralisação total do desenvolvimento da doença até o estádio III de estrias;

- O uso do telado para estudos de resistência da bananeira ao mal-de-Sigatoka, mostrou-se efiente e seguro como alternativa à tradicional avaliação de campo;

- A alta variabilidade patogênica demonstrada por isolados de Mycosphaerella musicola, indica que futuras avaliações de resistência de genótipos de bananeira, devem ser realizadas em condições controladas, utilizando a maior variabilidade possível da espécie no sentido de selecionar genótipos com resistência mais duradoura; 
- Parâmetros como freqüência de lesões $/ 50 \mathrm{~cm}^{2}$, severidade da doença, período de latência e período de desenvolvimento da doença, mostraram-se mais eficientes para o estudo da resistência. 


\section{7- REFERÊNCIAS BIBLIOGRÁFICAS GERAIS}

ALBUQUERQUE, P. S. B. Mycosphaerella musicola: produção de conídios in vitro; sensibilidade a fungicidas e avaliação da resistência em mudas de cultivares de bananeiras (Musa spp. ). Piracicaba, 1993. 94p. Dissertação (M.S.) - Escola Superior de Agricultura "Luiz de Queiróz"- Universidade de São Paulo.

BERGAMIN FILHO, A. \& AMORIM, L. Doenças de Plantas Tropicais: Epidemiologia e Controle Econômico, Editora Agronômica Ceres, São Paulo, 1996, 299p.

BEVERAGGI, A.; MOURICHON, X. \& SALLE, G. Study of host-parasite interactions in susceptible and resistant bananas inoculated with Cercospora fijiensis, pathogen of black leaf streak disease. IN: GANRY, J.(Ed.) Breeding banana and plantain for resistance to disease and pests. Proceedings, Montpellier, France, CIRAD-FLHOR, 1993, P.171-192.

BRUN, J. La cercoporiose du bananier en Guinée. Étude de la phase ascosporée du Mycosphaerella musicola Leach, Paris, 1963, 196p. Thèse - Institut Français de Recherches Fruitières Outre Mer.

CAMARGO, L. E. A. Mecanismos de variabilidade genética de agentes fitopatogênicos. IN: BERGAMIM FILHO, A. ; KIMATI, H. \& AMORIM, L. Manual de Fitopatologia volume 1: princípios e conceitos, Ed. Agronômica Ceres, São Paulo, cap. 23, p.455-469, 1995. 
CANTONE, F. A. \& DUNKLE, L. D. Resistance and susceptible Maize to Helminthosporium carbonum race 1 induced by prior inoculation with race 2 . Phytopathology, v. 80, p. 1221-1224, 1990.

CALPOUZOS, L. Studies on the Sigatoka disease of bananas and its fungus pathogen. Atkins Garden and Research Laboratory, Cienfuegos, Cuba, 1955. $70 \mathrm{p}$.

CALPOUZOS, L. Action of oil in the control of plant disease. An. Rev. Phytopath., v.4, p. 369-390, 1966.

CARLIER, J.; GONZALES DE LEON, D.; MOURICHON, X. \& ZAPATER, M. F. Genetic diversity of Mycosphaerella fijiensis, causal agent of black leaf streak in banana. IN: GANRY, J. Breeding banana and plantain for resistance to diseases and pests. Proceedings, Montpellier, France, CIRADFLHOR, 1993, P.193-199.

CARLIER, J.; MOURICHON, X.; GONZALES DE LEON, D.; ZAPATER, M. F.\& LEBRUN, M. H. DNA Restriction Fragment lengt Polimorphisms in Mycosphaerella species that cause banana leaf spot diseases. Phytopathology, v.84, p. 751-756, 1994.

CENTRO NACIONAL DE PESQUISA DE MANDIOCA E FRUTICULTURA TROPICAL-CNPMF, Banco de dados, ASE, 1997. CORDEIRO, Z. J. M. ; DANTAS, J.L.L.; SILVA, S. DE O. e ; SHEPHERD, K. \& ALVES, E. J. “Pioneira”- Nova variedade de banana. Cruz das Almas, BA, Embrapa/CNPMF, Banana em Foco, 109, 1993, 2p.

CORDEIRO, Z. J. M. \& KIMATI, H. Doenças da Bananeira (Musa spp) IN: KIMATI, H. ; AMORIM, L. ; BERGAMIM FILHO, A. ; CAMARGO, L. E. A. \& REZENDE, J. A. M. Manual de Fitopatologia, volume 2: Doenças das plantas cultivadas, Ed. Agronômica Ceres, São Paulo, cap. 13, p. 112136, 1997. 
DALY, J. M. Some aspects of host-patogen interactions. IN: HEITFUSS, R. \& WILlians, P. H.(Eds) Physiological Plant Pathology, New York: Springer Berlin Heidelberg, 1976, p.27-50.

DALISAY, R. F. \& KUC, J. A. Persistence of induced resistance and enhanced peroxidase and chitinase activities in cucumber plants. Physiol. and molec. Plant pathol., v.47, p. $315-327,1995$.

DANTAS, J. L. L. ; SHEPHRD, K. ; SOARES FILHO, W. dos S. et al. Programa de melhoramento genético da bananeira em execução no CNPMF/Embrapa-avanços obtidos. Cruz das Almas, BA, Embrapa/CNPMF, Documentos, 47, 1993. 42p.

DANTAS, J. L. L. ; SHEPHERD, K. ; SOARES FILHO, W. dos S. et al. Citogenética e melhoramento genético da bananeira (Musa spp), Cruz das Almas, BA, Embrapa/CNPMF, Documentos, 48, 1993 a, 61 p.

DAY, P. R. Plant Disease Resistance. Sci. Prog., Oxf. v.56, p.357-370, 1968.

ESCALANTE, J. V. Early evaluation of Musa genetic material from Embrapa against black Sigatoka. Informe final, CATIE, Turrialba, Costa Rica, 1993, 6p. (Relatório Técnico apresentado ao CNPMF pelo CATIE ).

ESKES, A. B. Bases genéticas da resistência horizontal a patógenos em plantas. Ciência e cultura, v.32, p.1464-1472, 1980.

FLOR, H. H. Inheritance of pathogenicity in Melampsora lini. Phytopathology, v. 32, p. 653-669, 1942.

FOURÉ, E. Les cercosporioses du bananier et leurs traitements. Comportament des variétés. Etude de la sensibilité variétale des bananiers et plantains à Mycosphaerella fijiensis Morelet au Gabon ( maladie des raies noires ). IIncubation et évolution de la maladie. Fruits, v.37, p. 749-766, 1982.

FOURÉ, E. ; GRISONI, M. \& ZURFLUH, R. Les cercosporioses du bananier et leurs traitements. Comportement des variétés. Etude de la sensibilité variétale des bananiers et plantains à Mycosphaerella fijiensis Morelet et de quelques 
caractéristiques biologiques de la maladie des raies noires au Gabon. Fruits, v.39, p.365-378, 1984.

FOURÉ, E. Les cercosporioses du bananier et leurs traitements. Comportement des variétés. Etude de la sensibilité variétale des bananiers et plantains à Mycosphaerella fijiensis Morelet au Gabon (maladie des raies noires). (suite III). Fruits, v.40, p.393-399, 1985.

FOURÉ, E. \& LESCOT, T. Variabilité génétique des Mycosphaerella inféodés au genre Musa. Mise en évidence de la présence au Cameroun sur bananiers et plantains d'une cercosporiose (Mycosphaerella musicola) au comportement pathogène atypique. Fruits, v.43, p.407-515, 1988.

FOURÉ, E. Characterization of the reactions of banana cultivars to Mycosphaerella fijiensis Morelet in Cameroon and genetics of resistance. IN: GANRY, J. (Ed.) Breeding banana and plantain for resistance to disease and pests. Proceedings, Montpellier, France, CIRAD-FLOR, 1993, p.159170.

FOURÉ, E. Leaf spot disease of banana and plantain caused by Mycosphaerella musicola and $M$. fijiensis. IN: JONES, D.R. The improvement and testing of Musa: a global partnership. Proceedings of the first global conference of the international Musa testing program held at FHIA, Honduras 27-30 april, Inibap, Montpellier, France, 1994, p. 37-46.

FUllertON, R. A. \& OLSEN, T. L. Patogenic diversity in Mycosphaerella fijiensis Morelet. IN: GANRY, J.(Ed.) Breeding banana and plantain for resistance to diseases and pests. Proceedings, Montpellier, France, CIRADFHLOR, 1993, P.201-211.

FRY, W. E. Principles of plant disease management, Orlando, Florida, Academic Press, INC., 1982, 377p. 
FUCHS, J. G. ; MOËNNE-LOCCOZ, Y. \& DÉFAGO, G. Nonpathogenic Fusarium oxysporum strain Fo47 induces resistance to Fusarium wilt in tomato. Plant Disease, v.81, p. 492 - 496, 1997.

GAUHL, F. Epidemiology and ecology of black Sigatoka (Mycosphaerella fijiensis Morelet) on plantain and banana (Musa spp) in Costa Rica, Central America. Inibap, Montpellier, France, 1994, 120p.

GALINDO, J. J.; GONZALEZ, M.; ESCALANT, J. V. \& JARAMILO, R. Evaluation of the resistance to Mycosphaerella fijiensis of germoplasm in the international Musa testing program. CATIE, Turrialba, 1990, 13p. (Relatório Técnico apresentado ao CNPMF pelo CATIE).

GOOS, R. D. \& TSCHIRCH, M. Greenhouse studies on the Cercospora leaf spot of banana. Trans. Brit. Mycol. Soc. V.46, p. 321-330, 1963.

HELLER, W. E. \& GESSLER, C. Induced sistemic resistance in tomato plants against Phytophthora infestans. J. Phytopathol., v.116, p.323-328, 1986.

HWANG, B. K.\& HEITEFUSS, R. Induced resistance of spring barley to Erysiphe graminis f. sp hordei. Phytopath. Z., v.103, p. 41-47, 1982.

ISSA, E. A cercosporiose da bananeira. O Biológico, v.29, p.65-73, 1953.

JACOME, L. H. \& SCHUH, W. Effects of leaf wetness duration and temperature on development of black Sigatoka disease on banana infected by Mycosphaerella fijiensis var. difformis. Phytopathology, v.82, p.515-520, 1992.

JACOME, L. H. \& SCHUH, W. Effect of temperature on growth and conidial production in vitro, and comparison of infection and aggressiveness in vivo among isolates of Mycosphaerella fijiensis var.difformis. Trop. Agric., v.70, p. 51-59, 1993.

JACOME, L. H. \& SCHUH, W. Spore production and artificial inoculation techniques for Mycosphaerella fijiensis var. difformis. Trop. Agric., v.70, p. 33-38, 1993a. 
JONES, D. R.(ed.) The improvement and testing of Musa: a global partnership. Proceedings of the first global conference of the intermational Musa testing program held at FHIA, Honduras 27-30 april 1994, Inibap, France, 1994. 303p.

JONES, D. R Rapid assessment of Musa for reaction to Sigatoka disease. Fruits, v.50, p. 11-22, 1995.

JOHNSON, R. Durable resistance: Definition of, genetic control, and attainment in plant breeding. Phytopathology, v.71, p.567-568, 1981.

KESSMANN, H. ; STAUB, T. ; LIGON, J. ; OOSTENDORP, M. \& RYALS, J. Activation of sistemic acquired disease resistance in plants. European Journal of Plant Pathology, v.100, p.359 - 369, 1994.

KIMATI, H. \& GALLI, F. IN: GALLI, F. Manual de Fitopatologia Doenças das plantas cultivadas. V II, Editora Agronômica Ceres, São Paulo, 1980, cap. 8, p.87-101.

KRUGNER, T. L. \& BACCHI, M. A. Fungos. IN: BERGAMIM FILHO, A. ; KIMATI, H. \& AMORIM, L. Manual de Fitopatologia volume 1: princípios e conceitos, Ed. Agronômica Ceres, São Paulo, cap. 4, p.46-96, 1995.

KUC, J. \& RICHMOND, S. Aspects of protection of cucumber against Colletotrichum lagenarium by Colletotrichum lagenarium. Phytopathology, v.67, p.533 - 536, 1977.

LIU, L. ; KLOEPPER, J. W. \& TUZUN, S. Induction of sitemic resistance in cucumber by plant growth-promoting rhizobacteria: Duration of protection and effect of host resistance on protection and root colonization. Phytopathology, v.85, p.1064-1068, 1995.

MARTINEZ, J. A. O mal-de-Sigatoka e sua importância econômica para a bananicultura do Estado de São Paulo. O Biológico, v.66, p. 271-280, 1970. 
MARIM VARGAS, D. \& ROMERO CALDERÓN, R. El combate de la Sigatoka negra. Boletin, n. 4, CORBANA, Departamento de Investigaciones, San José, Costa Rica, /1989?/, 21p.

MEREDITH, D. S. \& LAWRENCE, J. S. Black leaf streak disease of bananas (Mycosphaerella fijiensis): Suscetibility of cultivars. Trop. Agric., v.47, p. 275-287, 1970.

McGAHAN, M. W. \& FULTON, R. H. Leaf spot of bananas caused by Mycosphaerella musicola: A comparative anatomical study of juvenile and adult leaves in relation to lesion morphology. Phytopathology, v.55, p.1179$1182,1965$.

Mc INTYRE, J. L. \& MILLER, P. M. Protection of tobacco aginst Phytophthora parasitica var. nicotianae by cultivar-nonpathogenic races, cell-free sonicates, and Pratylenchus penetrans. Phytopathology, v.68, p.235-239, 1978.

MONNIER, E. Variabilité génétique des Mycosphaerella inféodés au genre Musa. Essai de mise en évidence d'échanges d'informations par fusion de cellules végétatives. Fruits, v.41, p. 15-23, 1986.

MOURICHON, X.; PETER, D. \& ZAPATER, M.F.e. Inoculation expérimentale de Mycosphaerella fijiensis Morelet sur de jeunes plantules de bananiers issues de culture in vitro. Fruits, v.42, p. 195-198, 1987.

MOURICHON, X. Mycosphaerella fijiensis: Diversity and possibilities for the early screening of germoplasm for resistance. IN: JONES, D. R. (Ed.) The improvement and testing of Musa: a global partnership. Proceedings of the first global conference of the International Musa Testing Program held et FHIA, Honduras, 27-30 april, 1994, Inibap, France, 1994. p.47-53.

NELSON, R.R.(ed.) Breeding plants for disease resistance - concepts and applications. Univesity Park and london, The Pensylvania state University Press, 1973, 401p. 
OUCHI, S. ; OKU, H. ; HIBINO, C. \& AKIYAMA, I. Infection of accessibility and resistance in leaves of barley by some races of Erysiphe graminis. Phythopath. Z., v.79, p.24-34, 1974.

PASCHOLATI, S. F. \& LEITE, B. Hospedeiro: Mecanismos de resistência. IN: BergamiM FILHO, A.; KIMATI, H. \& AMORIM, L. Manual de Fitopatologia, volume 1: princípios e conceitos, Ed. Agronômica Ceres, São Paulo, cap. 22, p.417-453, 1995.

PARLEVLIET, J. E. Evidence of diferential interaction in the poligenic Hordeum vulgare-Puccinia hordei relation during epidemic development. Phythopathology, v.67, p.776-778, 1977.

RAHE, J. E. ; KUC, J. ; CHUANG. C. M. \& WILliAMS, E. B. Induced resistance in Phaseolus vulgaris to bean anthracnose. Phytopathology, v. 59, p.1641- 1645, 1969.

SHEPHERD, K. Genetic improvement of bananas in Brasil: aspects related to resistance to the genus Mycosphaerella. IN: FULLERTON, R. A. \& STOVER, R. H. (Ed.) Sigatoka leaf spot of bananas. Proceedings of an international workshop held at San José, Costa Rica, 1989. Inibap, Montpellier, France, 1990. p. 243-251.

SHEPHERD, K.; SILVA, S. de O. e; DANTAS, J. L. L.; CORDEIRO, Z. J. M. \& SOARES FILHO, W. dos S. Hibridos tetraplóides de bananeira avaliados no CNPMF. Rev. Bras. Frutic., v. 14, p.33-39, 1992.

SHILLINGFORD, C. A. Varietal susceptibility of bananas to infection by Mycosphaerella musicola in sprayed and unsprayed plots. Trop. Agric., 52(2):157-165, 1974.

SIMMONDS, J. H. Banana leaf spot. Queni. Agric. J., v.39, p.21-40, 1933.

SIMMONDS, N. W. bananas, 2a ed.,London, Longman, 1966. 512p.

SIMONS, M. D. Polygenic resistance to plant diseases and its use in breeding resistant cultivars. J. Environ. Quality, v.1, p.232-239, 1972. 
SOARES FILHO, W. dos S.; ALVES, E. J.; CORDEIRO, Z. J. M.; CUNHA, M. A. P. da; SHEPHERD, K.; DANTAS, J. L. L. \& BORGES, A. L. Programa de Pesquisa de Banana e "Plátano" em execução no CNPMF-Embrapa. Cruz das Almas, BA, Embrapa-CNPMF, Documentos, 28. 1990, 15p.

STAEL, G. Notes on cercospora leaf spot of bananas (Cercospora musae). Trop. Agric., v.14, p. 257-264, 1937.

STAKMAN, E. C. \& CHRISTENSEN The problem of breeding resistant varieties. IN: HORSFALL, J. G. \& DIMOND, A. E. PLANT PATHOLOGY: an advanced treatise, New York, Academic Press, v. III , cap.14, 1960, p.567-625.

STOVER, R. H. Sexuality and heterothallism in Mycosphaerella musicola. Can. J. Bot., v.41, 1531-1532, 1963.

STOVER, R. H. Leaf spot of banana caused by Mycosphaerella musicola: Factors influencing production of fructifications and ascospores. Phytopathology, v.54, p.1320-1326, 1964.

STOVER, R. H. \& FULTON, R. H. Leaf spot of bananas caused by Mycosphaerella musicola: The relation of infection sites to leaf development and spore type. Trop. Agric., v.43, p.117-129, 1966.

STOVER, R. H. A proposed international scale for estimating intensity of banana leaf spot (Mycosphaerella musicola). Trop. Agric.,v.48, p.185-196, 1971.

STOVER, R. H. Banana, plantain and abaca disease. Commonwealth Mycological Institute, England, 1972. 316p.

STOVER, R.H. Distribution and cultural characteristics of the pathogens causing banana leaf spot. Trop. Agric., v.53, p. 112-114, 1976.

STOVER, R.H. Sigatoka leaf spot of bananas and plantains. Plant Disease, v.64, p.750-756, 1980.

STOVER, R. H. \& SIMMONDS, N. W. Bananas. $3^{a}$ ed., New York, 1987, 468p. 
THURSTON, H. D. Relationship of general resistance: late blight of potato. Phytopathology, v.61, p.620-626, 1971.

VAN DER PLANK, J. E. Disease resistance in plants. New York, Academic Press, 1968, 206p.

VAN DER PLANK, J. E. Plant Disease: Epidemics and control. New York, Academic Press, 1963,

VAKILI, N. G. Responses of Musa acuminata species and edible cultivars to infection by Mycosphaerella musicola. Trop. Agric., v.45, p.13-22, 1968. 